\title{
SUMMARY OF GROUND-WATER HYDROLOGY OF THE CAMBRIAN-ORDOVICIAN AQUIFER SYSTEM IN THE NORTHERN MIDWEST, UNITED STATES
}

\section{REGIONAL AOUIFER-SYSTEM ANALYSIS}

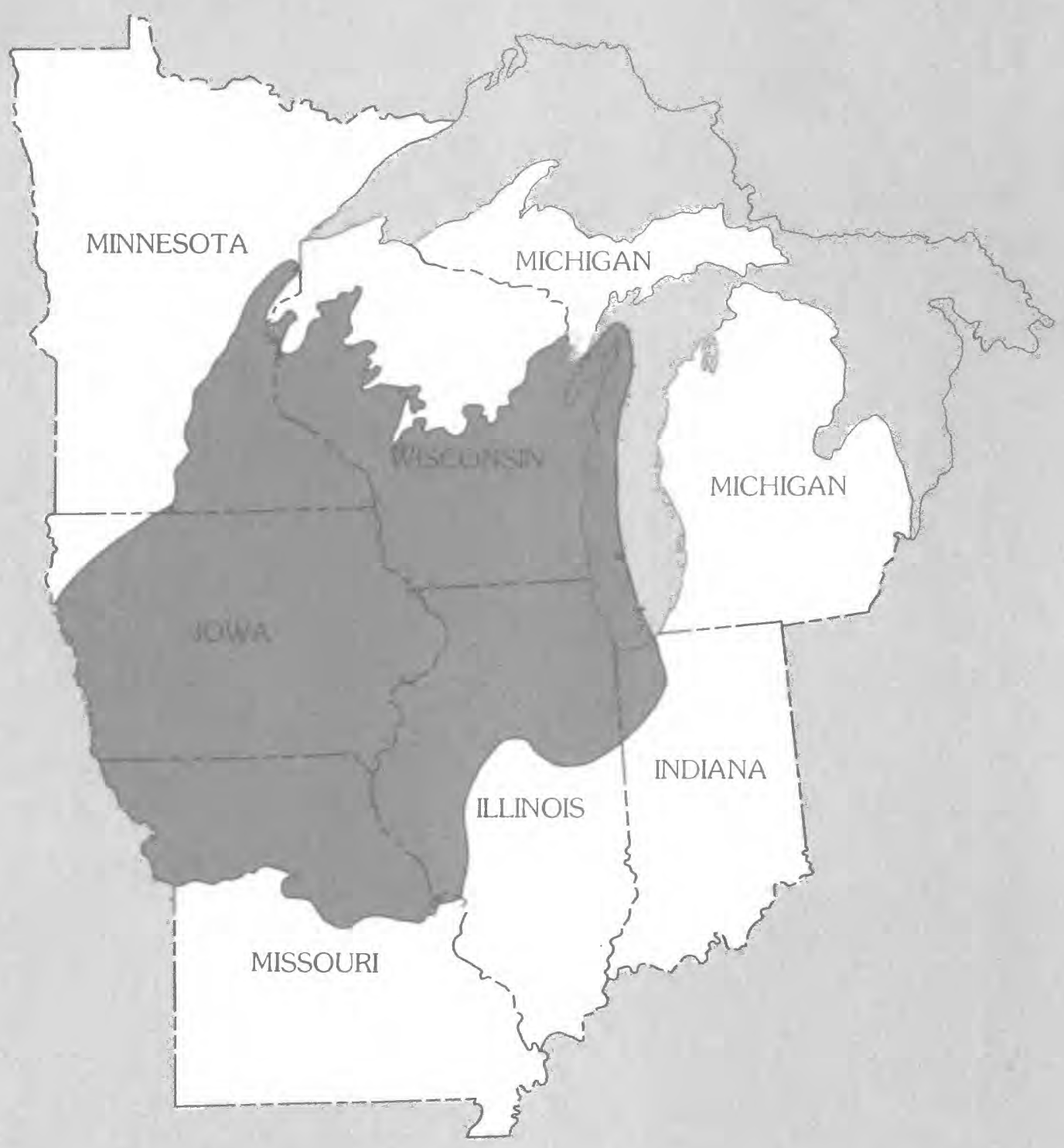

U. S. GEOLOGICAL SURVEY PROFESSIONAL PAPER 1405-A 


\section{AVAILABILITY OF BOOKS AND MAPS OF THE U.S. GEOLOGICAL SURVEY}

Instructions on ordering publications of the U.S. Geological Survey, along with prices of the last offerings, are given in the current-year issues of the monthly catalog "New Publications of the U.S. Geological Survey." Prices of available U.S. Geological Survey publications released prior to the current year are listed in the most recent annual "Price and Availability List." Publications that are listed in various U.S. Geological Survey catalogs (see back inside cover) but not listed in the most recent annual "Price and Availability List" are no longer available.

Prices of reports released to the open files are given in the listing "U.S. Geological Survey Open-File Reports," updated monthly, which is for sale in microfiche from U.S. Geological Survey Book and Open-File Report Sales, Box 25425, Denver, CO 80225. Reports released through the NTIS may be obtained by writing to the National Technical Information Service, U.S. Department of Commerce, Springfield, VA 22161; please include NTIS report number with inquiry.

Order U.S. Geological Survey publications by mail or over the counter from the offices given below.

BY MAIL

\section{Books}

Professional Papers, Bulletins, Water-Supply Papers, Techniques of Water-Resources Investigations, Circulars, publications of general interest (such as leaflets, pamphlets, booklets), single copies of Earthquakes \& Volcanoes, Preliminary Determination of Epicenters, and some miscellaneous reports, including some of the foregoing series that have gone out of print at the Superintendent of Documents, are obtainable by mail from

\section{U.S. Geological Survey, Book and Open-File Report Sales Box 25425 \\ Denver, CO 80225}

Subscriptions to periodicals (Earthquakes \& Volcanoes and Preliminary Determination of Epicenters) can be obtained ONLY from the

\section{Superintendent of Documents \\ Government Printing Office \\ Washington, D.C. 20402}

(Check or money order must be payable to Superintendent of Documents.)

Maps

For maps, address mail orders to

\section{U.S. Geological Survey, Map Sales Box 25286 \\ Denver, CO 80225}

Residents of Alaska may order maps from

$$
\begin{gathered}
\text { U.S. Geological Survey, Map Sales } \\
101 \text { Twelfth Ave. - Box } 12 \\
\text { Fairbanks, AK } 99701
\end{gathered}
$$

\section{OVER THE COUNTER}

\section{Books}

Books of the U.S. Geological Survey are available over the counter at the following U.S. Geological Survey Public Inquiries Offices, all of which are authorized agents of the Superintendent of Documents:

- ANCHORAGE, Alaska-Rm. 101, 4230 University Dr.

- ANCHORAGE, Alaska-Federal Bldg., Rm. E-146, 701 C St.

- DENVER, Colorado-Federal Bldg., Rm. 169, 1961 Stout St.

- LAKEWOOD, Colorado-Federal Center, Bldg. 810

- MENLO PARK, California-Bldg. 3 (Stop 533), Rm. 3128, 345 Middlefield Rd.

- RESTON, Virginia-503 National Center, Rm. 1C402, 12201 Sunrise Valley Dr.

- SALT LAKE CITY, Utah-Federal Bldg., Rm. 8105, 125 South State St.

- SAN FRANCISCO, California-Customhouse, Rm. 504, 555 Battery St.

- SPOKANE, Washington-U.S. Courthouse, Rm. 678, West 920 Riverside Ave.

- WASHINGTON, D.C.-Main Interior Bldg., 2600 corridor, 18 th and C Sts., NW.

\section{Maps}

Maps may be purchased over the counter at the U.S. Geological Survey offices where books are sold (all addresses in above list) and at the following U.S. Geological Survey offices:

- ROLLA, Missouri-1400 Independence Rd.

- DENVER, Colorado-Map Distribution, Bldg. 810, Federal Center

- FAIRBANKS, Alaska-New Federal Bldg., 101 Twelfth Ave. 


\section{Summary of Ground-Water Hydrology of the Cambrian-Ordovician Aquifer System in the Northern Midwest, United States}

By H.L. YOUNG

REGIONAL AQUIFER-SYSTEM ANALYSIS-NORTHERN MIDWEST

U.S. GEOLOGICAL SURVEY PROFESSIONAL PAPER 1405-A

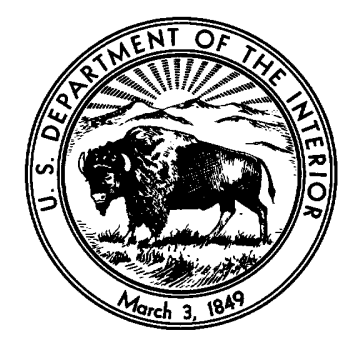

UNITED STATES GOVERNMENT PRINTING OFFICE, WASHINGTON：1992 


\title{
U.S. DEPARTMENT OF THE INTERIOR MANUEL LUJAN, Jr., Secretary
}

\section{U.S. GEOLOGICAL SURVEY}

\author{
Dallas L. Peck, Director
}

\begin{abstract}
Any use of trade, product, or firm names in this publication is for descriptive purposes only and does not imply endorsement by the

U.S. Government
\end{abstract}

\section{Library of Congress Cataloging in Publication Data}

Young, H.L.

Summary of ground-water hydrology of the Cambrian-Ordovician aquifer system in the northern Midwest, United States / by H.L. Young.

p. cm. - (Regional aquifer-system analysis) (U.S. Geological Survey professional paper ; 1405-A)

Includes bibliographical references.

Supt. of Docs. no.: I 19.16:1405-A

1. Water, Underground-Middle West. 2. Aquifers-Middle West. 3. Geography, Stratigraphic-Cambrian. 4. Geography, Stratigraphic-Ordovician. I. Title. II. Series. III. Series: U.S. Geological Survey professional paper. GB1017.Y68 1991

For sale by Book and Open-File Report Sales, U.S. Geological Survey, Federal Center, Box 25425, Denver, CO 80225 


\section{FOREWORD}

\section{THE REGIONAL AQUIFER-SYSTEM ANALYSIS PROGRAM}

The Regional Aquifer-System Analysis (RASA) Program was started in 1978 following a congressional mandate to develop quantitative appraisals of the major ground-water systems of the United States. The RASA Program represents a systematic effort to study a number of the Nation's most important aquifer systems, which in aggregate underlie much of the country and which represent an important component of the Nation's total water supply. In general, the boundaries of these studies are identified by the hydrologic extent of each system and accordingly transcend the political subdivisions to which investigations have often arbitrarily been limited in the past. The broad objective for each study is to assemble geologic, hydrologic, and geochemical information, to analyze and develop an understanding of the system, and to develop predictive capabilities that will contribute to the effective management of the system. The use of computer simulation is an important element of the RASA studies, both to develop an understanding of the natural, undisturbed hydrologic system and the changes brought about in it by human activities, and to provide a means of predicting the regional effects of future pumping or other stresses.

The final interpretive results of the RASA Program are presented in a series of U.S. Geological Survey Professional Papers that describe the geology, hydrology, and geochemistry of each regional aquifer system. Each study within the RASA Program is assigned a single Professional Paper number, and where the volume of interpretive material warrants, separate topical chapters that consider the principal elements of the investigation may be published. The series of RASA interpretive reports begins with Professional Paper 1400 and thereafter will continue in numerical sequence as the interpretive products of subsequent studies become available.

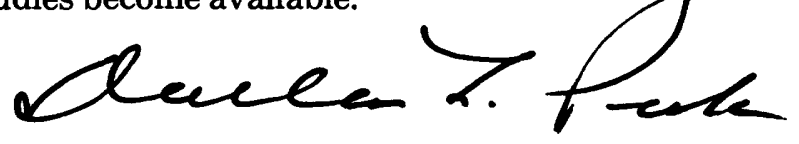

Dallas L. Peck

Director 



\section{CONTENTS}

\begin{tabular}{|c|c|c|c|}
\hline & Page & & Page \\
\hline Introduction..... & 2 & Regional Model ................. & 36 \\
\hline Hydrogeology ........... & 4 & Conceptual Model .......................... & 36 \\
\hline 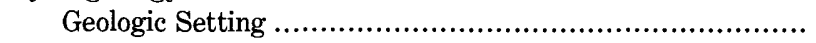 & 4 & Steady-State Simulation..................................... & 38 \\
\hline Hydrogeologic Units & 5 & Transient Simulation & 38 \\
\hline Recharge, Ground-Water Movement, and Discharge........... & 15 & Subregional Models ................... & 40 \\
\hline 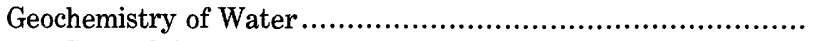 & 20 & Chicago-Milwaukee Area Model & 43 \\
\hline Hydrochemical Facies.. & 21 & Topics for Further Investigation .. & 50 \\
\hline Dissolved Solids ...................................... & 21 & Hydraulic Characteristics of Confining Units...... & 50 \\
\hline Trace Elements and Minor Constituents ..................... & 25 & Relation of Confining Units to Water Quality .................. & 50 \\
\hline Effects of Pleistocene Glaciation on Ground-Water & & 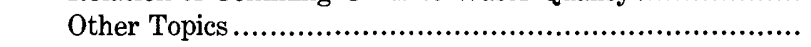 & 51 \\
\hline 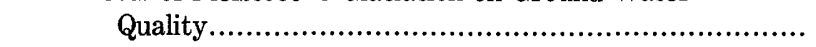 & 25 & Conclusions & 51 \\
\hline Ground-Water Development and Its Effects......................... & 30 & 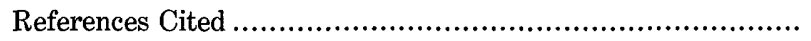 & 52 \\
\hline
\end{tabular}

\section{ILLUSTRATIONS}

Figures 1-5. Maps showing:

1. Location and general features of the area of study of the Cambrian-Ordovician aquifer system.................... A3

2. Extent of major glaciations in the northern Midwest during the Pleistocene Epoch ...................................

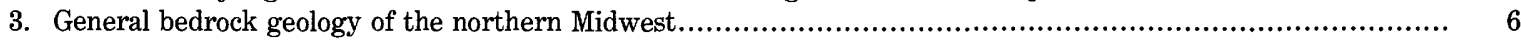

4. Structural surface of the Precambrian basement in the northern Midwest ............................................

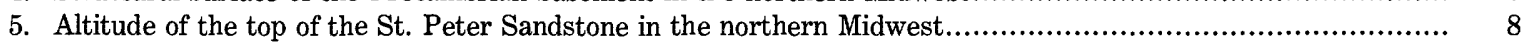

6-9. Maps of northern Midwest showing thickness of:

6. Maquoketa confining unit in the northern Midwest.................................................................

7. St. Peter-Prairie du Chien-Jordan aquifer in the northern Midwest ............................................

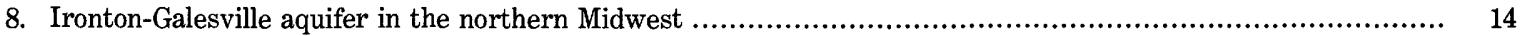

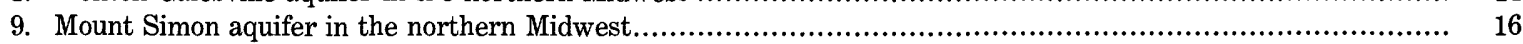

10. Map showing generalized water table and major surface-water drainage network in the northern Midwest................. 17

11. Generalized hydrogeologic section across southern Wisconsin illustrating typical predevelopment flow systems in the northern Midwest

12-19. Maps of northern Midwest showing:

12. Approximate predevelopment potentiometric surface for the St. Peter-Prairie du Chien-Jordan aquifer in the northern Midwest...

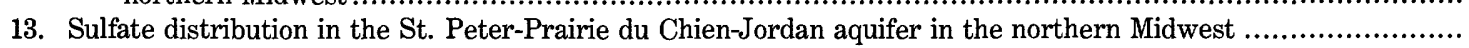

14. Hydrochemical facies of ground water in the Cretaceous and drift aquifers in the northern Midwest ................

15. Hydrochemical facies of ground water in the Mount Simon and St. Peter-Prairie du Chien-Jordan aquifers in the northern Midwest.

16. Dissolved-solids distribution in the Mount Simon aquifer in the northern Midwest.

17. Dissolved-solids distribution in the St. Peter-Prairie du Chien-Jordan aquifer in the northern Midwest .............

18. Distribution of boron in the Mount Simon and St. Peter-Prairie du Chien-Jordan aquifers in the northern Midwest.

19. Distribution of $\delta^{18} \mathrm{O}$ ratio in the Cambrian-Ordovician aquifer system in the northern Midwest......................

20. Graphs showing ground-water withdrawals from the Cambrian-Ordovician aquifer system in the Chicago and Twin

Cities areas, $1864-1980$ . 10 
21-23. Maps showing:

21. Major areas of ground-water withdrawal from the Cambrian-Ordovician aquifer system in the northern Midwest, 1979-1980

22. Generalized potentiometric surface for the St. Peter-Prairie du Chien-Jordan aquifer in the northern Midwest, 1980

23. Decline in head in the composite Cambrian-Ordovician aquifer system in the Chicago-Milwaukee area, $1864-1980$

24-27. Maps of northern Midwest showing:

24. Location and areal extent of regional and subregional ground-water flow models of the Cambrian-Ordovician aquifer system in the northern Midwest....

25. Simulated predevelopment head in the St. Peter-Prairie du Chien-Jordan aquifer in the northern Midwest ......

26. Simulated 1980 head in the St. Peter-Prairie du Chien-Jordan aquifer in the northern Midwest.....................

27. Simulated decline in head in the St. Peter-Prairie du Chien-Jordan aquifer, 1861-1980......

28. Schematic diagram of simulated water budget for the Cambrian-Ordovician aquifer system in the northern Midwest .....

29. Geohydrologic section along Chicago-Milwaukee area model column 21.

30. Map showing simulated predevelopment head and vertical flow direction in the St. Peter-Prairie du Chien-Jordan aquifer in the Chicago-Milwaukee area ....

31. Schematic diagram of simulated predevelopment ground-water flow across the top of the St. Peter-Prairie du ChienJordan aquifer within the area of the Chicago-Milwaukee flow system .....

32. Map showing simulated 1985 head and vertical flow direction in the composite Cambrian-Ordovician aquifer system in the Chicago-Milwaukee area......

33. Hydrograph for well $W k-07 / 17 E / 05-0020$ completed in the St. Peter-Prairie du Chien-Jordan aquifer in northwestern Waukesha County, Wisconsin.

34. Schematic diagram of simulated 1985 ground-water flow across the top of the St. Peter-Prairie du Chien-Jordan aquifer within the area of the Chicago-Milwaukee flow system

\section{TABLE}

TABLE 1. Hydrogeologic-unit nomenclature used in the study of the Cambrian-Ordovician aquifer system ......

\section{METRIC CONVERSION FACTORS AND VERTICAL DATUM}

For readers who wish to convert measurements from the inch-pound system of units to the metric system of units, the conversion factors are listed below:

\begin{tabular}{rcl}
\hline Multiply inch-pound units & By & To obtain metric units \\
\hline foot $(\mathrm{ft})$ & 0.3048 & meter $(\mathrm{m})$ \\
mile $(\mathrm{mi})$ & 1.609 & kilometer $(\mathrm{km})$ \\
square mile $\left(\mathrm{mi}^{2}\right.$ & 2.590 & square kilometer $\left(\mathrm{km}^{2}\right)$ \\
inch per year $(\mathrm{in} / \mathrm{yr})$ & 25.4 & millimeter per year $(\mathrm{mm} / \mathrm{yr})$ \\
cubic foot per second $\left(\mathrm{ft}^{3} / \mathrm{s}\right)$ & 0.02832 & cubic meter per second $\left(\mathrm{m}^{3} / \mathrm{s}\right)$ \\
gallon per minute $(\mathrm{gal} / \mathrm{min})$ & 0.06308 & liter per second $(\mathrm{L} / \mathrm{s})$ \\
million gallons per day $\left(\mathrm{Mgal}^{2} / \mathrm{d}\right)$ & 0.04381 & cubic meter per second $\left(\mathrm{m}^{3} / \mathrm{s}\right)$ \\
foot squared per day $\left(\mathrm{ft}^{2} / \mathrm{d}\right)$ & 0.09290 & meter squared per day $\left(\mathrm{m}^{2} / \mathrm{d}\right)$ \\
\hline
\end{tabular}

Sea Level: In this report "sea level" refers to the National Geodetic Vertical Datum of 1929 (NGVD of 1929) - a geodetic datum derived from a general adjustment of the first-order level nets of both the United States and Canada, formerly called Sea Level Datum of 1929. 


\title{
SUMMARY OF GROUND-WATER HYDROLOGY OF THE CAMBRIAN- ORDOVICIAN AQUIFER SYSTEM IN THE NORTHERN MIDWEST, UNITED STATES
}

\author{
By H.L. Young
}

\begin{abstract}
The Cambrian-Ordovician aquifer system contains very productive aquifers throughout an area of about 161,000 square miles in the northern Midwest. The aquifer system is used extensively for industrial and rural water supplies and is the primary source of water for many municipalities in most of its area of occurrence, except in Indiana, central and southern Illinois, and western Iowa, where the aquifer system contains saline water. About 680 million gallons per day was withdrawn from drilled wells in the aquifer system in 1980.

Rocks of Cambrian and Ordovician age, mainly marine sandstones and carbonate rocks, constitute most of the bedrock and subcrop beneath glacial drift in southeastern Minnesota, northeastern Iowa, Wisconsin, northern Illinois, and extreme northwestern Indiana. These strata dip generally to the south and east off the Transcontinental arch in Minnesota and the Wisconsin arch, which are structurally high areas of the Precambrian basement, into the structural lows of the Forest City basin of southwestern Iowa, the Illinois basin, and the Michigan basin.

The Cambrian and Ordovician rocks are buried by younger rocks in the remainder of Iowa, Illinois, and Indiana and in most of northern Missouri. Silurian and Devonian carbonate rocks immediately overlie the Cambrian and Ordovician rocks in those areas and are termed the "Silurian-Devonian aquifer" in this study. The balance of the Devonian rocks and the overlying Mississippian and Pennsylvanian rocks generally are fine-grained sediment or dense carbonate rocks and collectively are considered to be a regional confining unit. Most of the area is covered by a veneer of glacial drift, which, along with Cretaceous sandstone in northwestern Iowa, is treated as a regional water-table aquifer.

The Cambrian-Ordovician aquifer system is composed of six hydrogeologic units, which are, in descending order, the Maquoketa confining unit, St. Peter-Prairie du Chien-Jordan aquifer, St. LawrenceFranconia confining unit, Ironton-Galesville aquifer, Eau Claire confining unit, and Mount Simon aquifer. The uppermost confining unit is the least permeable; it consists primarily of the Maquoketa Shale but includes the dense carbonate rocks of the Galena Dolomite and the Decorah, Platteville, and Glenwood Formations where they are overlain by the Maquoketa Shale. The presence of the Maquoketa in Iowa, eastern Wisconsin, northeastern Illinois, and Indiana effectively confines the entire aquifer system below.
\end{abstract}

The aquifer system is a leaky-artesian system in which movement of ground water is controlled partly by the internal confining units. In the northern outcrop area, unconfined conditions prevail in shallow parts of the aquifer system and where the system is thin. Much of the recharge in upland areas discharges to streams through local flow systems, which are no more than a few miles in length. The remainder of the recharge moves slowly downward to deeper formations and downgradient to form or join the regional flow system.

Computer simulations of regional ground-water flow improve understanding of the regional character of the Cambrian-Ordovician aquifer system. Ground-water flow in the confined part of the aquifer system is mainly horizontal, away from the structural highs in the north, toward the structural basins in the south and east. The rate of ground-water movement is very slow, and the flux along flow paths into the basins decreases because of a progressive loss of head and small but widespread upward leakage. Saline water in the basins restricts movement of freshwater into the deeper parts of the basins, thereby forcing flow upward through confining units. Principal regional discharge areas are the Mississippi and Missouri Rivers, the Illinois and Michigan structural basins, and Lake Michigan. However, the lake is not in direct hydraulic connection with the Cambrian-Ordovician aquifer system and receives flow primarily from the Silurian-Devonian aquifer, which it directly overlies. The longest regional flow paths originate in recharge areas in northwestern Iowa and extend southeastward as much as $\mathbf{4 0 0}$ miles toward the Illinois basin.

Simulated predevelopment recharge and discharge for the CambrianOrdovician aquifer system balance at 351 million gallons per day.

Development of the aquifer system began in various parts of the northern Midwest in the 1860's and 1870's with the drilling of deep, generally flowing artesian wells near Lake Michigan in eastern Wisconsin and northeastern Illinois and along the valleys of the Mississippi River and its tributaries. Initial heads of 186 and 130 feet above Lake Michigan at Milwaukee and Chicago, respectively, have been reported. Large-scale pumping has produced cones of depression in these two areas, with respective head declines of as much as 375 and 900 feet. Other major pumping centers generally have had much smaller declines. The largest withdrawals from the aquifer system were about 180 million gallons per day in each of the major metropolitan areas of Chicago and Minneapolis-St. Paul (Twin Cities). However, the total decline in head in the St. Peter-Prairie du Chien-Jordan aquifer in the Twin Cities by 1980 was only 90 feet because the aquifer is unconfined. 
Most of the eastern two-thirds of Iowa, where the aquifer system is tightly confined, is characterized by more than 50 feet of head decline, with 200 feet or more at Mason City and the Quad Cities.

Pumpage from the Cambrian-Ordovician aquifer system throughout the study area averaged 683 million gallons per day for the period 1976-80. Results of a transient-model simulation show that recharge increased over predevelopment recharge by 447 million gallons per day. Natural discharge decreased by 99 million gallons per day, and 137 million gallons per day was released from aquifer storage.

Mineralization of ground water in the aquifer system increases from slightly mineralized calcium magnesium bicarbonate water in the northern recharge areas, through more mineralized, mixed water types with increased sodium and sulfate, to highly mineralized sodium chloride brines in the deeper parts of the structural basins.

\section{INTRODUCTION}

Much of the sedimentary rock that overlies the Precambrian crystalline basement rock in the northern Midwest consists of the marine sandstone and carbonate rocks that make up the Cambrian and Ordovician Systems. The entire Cambrian and Ordovician sequence forms the major regional aquifer system of the area. The Cambrian-Ordovician aquifer system is essentially continuous and contains very productive aquifers throughout an area of about $161,000 \mathrm{mi}^{2}$ (square miles) in southeastern Minnesota, Wisconsin, Iowa, northern Missouri, and northern Illinois (fig. 1). Many metropolitan areas depend on the aquifer system for municipal and industrial water supplies. It also is used extensively for self-supplied industrial, rural, and domestic water supplies.

Development of the Cambrian-Ordovician aquifer system in the northern Midwest began as early as 1864 when a flowing well $711 \mathrm{ft}$ (feet) deep was drilled in Chicago. By the late 1800 's many wells had been drilled, especially where flowing wells were obtainable. Withdrawal of ground water from the aquifer system has increased almost steadily in relation to the growth in population, attaining rates of about $180 \mathrm{Mgal} / \mathrm{d}$ (million gallons per day) in 1980 in the Chicago and Minneapolis-St. Paul areas. The hydraulic head in the aquifer system has declined hundreds of feet since the late 1800's in the Chicago and Milwaukee areas and to a somewhat lesser extent in other areas, such as Minneapolis-St. Paul, Green Bay, Wis., and Des Moines, Mason City, and Cedar Rapids, Iowa. Increased ground-water withdrawals in the future will cause continued or increased waterlevel declines.

The aquifer system contains highly mineralized water in several places, especially in its deepest parts, generally coinciding with regional discharge or structurally low areas. This mineralized water is unsuitable for most uses and limits ground-water development in some areas. It is a possible source of contamination to fresh- water supplies in areas of large ground-water withdrawals, such as northeastern Illinois, southeastern Wisconsin, and central Iowa.

In October 1978, the U.S. Geological Survey (USGS) began a regional assessment of the Cambrian-Ordovician aquifer system in the northern Midwest (Steinhilber and Young, 1979,) as part of its national program of Regional Aquifer-System Analysis (RASA) (See Foreword of this report, and Bennett, 1979).

Although many parts of the aquifer system have been studied in each State within the project area as part of the USGS's Cooperative Program and by State and local agencies, the regional study has the obvious benefit of assessing the aquifer system in its entirety. The major goals of the RASA program are to (1) gain an understanding of each hydrogeologic system, including the nature of the hydrogeologic units and the ground-water flow system, and the chemical quality of the water, and (2) describe the regional interaction of components of the system, especially as affected by large-scale withdrawal of ground water.

The border of the area of study of the CambrianOrdovician aquifer system (fig. 1) delimits either the natural physical or hydrologic boundaries of the aquifer system or places where aquifers in the system are not used because of water containing extremely high dissolved solids (greater than $10,000 \mathrm{mg} / \mathrm{L}$ (milligrams per liter)). The northern boundary, from northwestern Iowa to northeastern Wisconsin, delineates the erosional edge of Cambrian-age rocks overlying crystalline basement rocks of Precambrian age. The Missouri River is a ground-water discharge line and forms the western and southwestern boundary. Beyond the eastern and southeastern boundary in Michigan, Illinois, and Indiana, water in the aquifer system is highly mineralized.

The rocks of the aquifer system subcrop beneath glacial drift or crop out in much of the northern part of the study area, but in most of the remainder of the area they are overlain by the Maquoketa Shale, the uppermost Ordovician rock unit, which has very low permeability. The aquifer system is bounded below by impermeable Precambrian basement rock. Other rocks in the study area are minor aquifers regionally, but can be important locally. The major local aquifers consist of Silurian and Devonian carbonate rocks, Cretaceous sandstone, and Quaternary sand and gravel. Some wells developed in the Cambrian-Ordovician aquifer system also are open to the Silurian and Devonian carbonate rocks; thus, the Silurian-Devonian aquifer was also included in the study.

The purpose of this report is to summarize the findings of the regional study of the Cambrian-Ordovician aquifer system. The report includes discussions of the hydrogeology, geochemistry, and development of ground water 


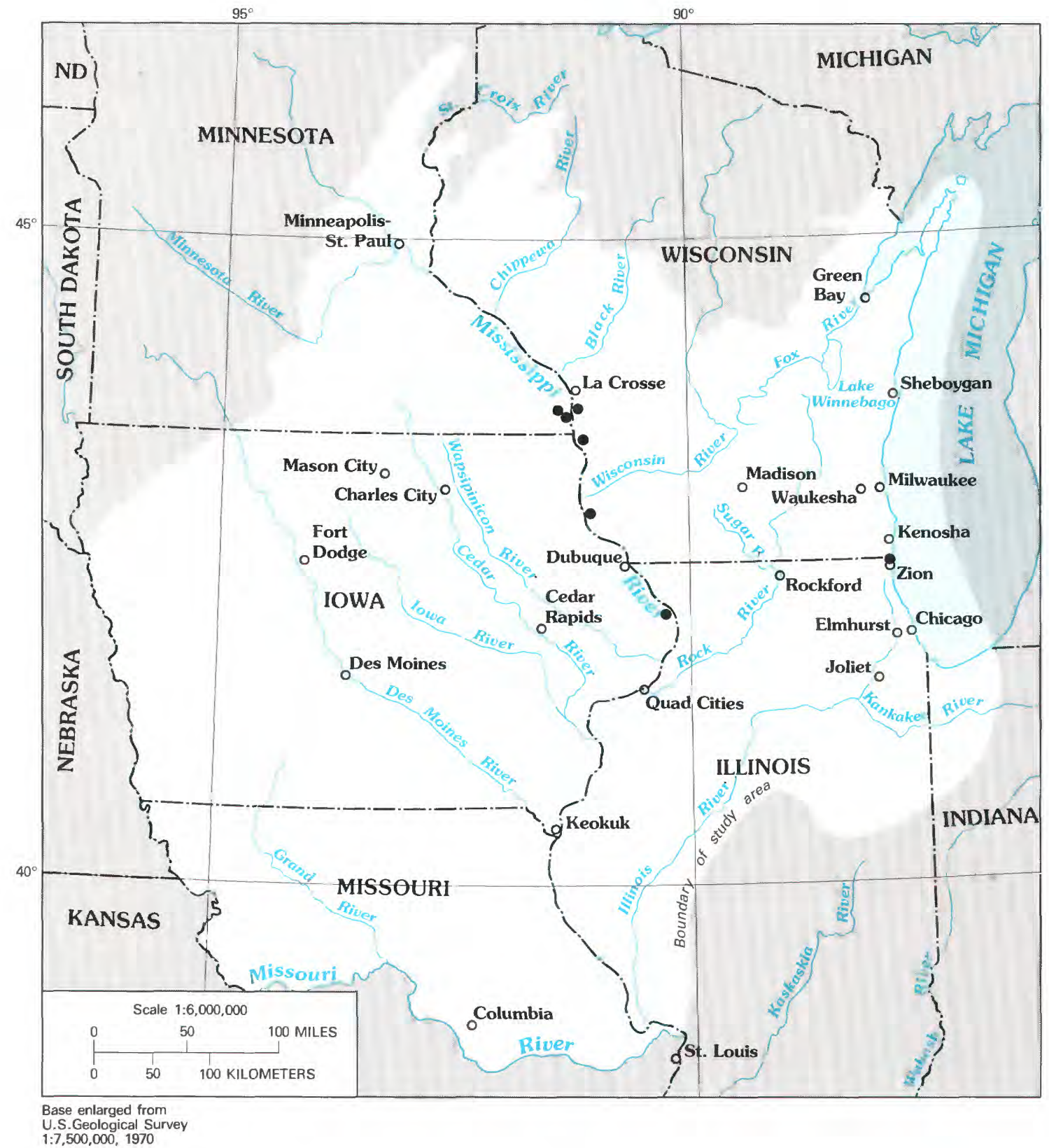

EXPLANATION

- U.S. GEOLOGICAL SURVEY TEST WELL DRILLED FOR THE NORTHERN MIDWEST REGIONAL AQUIFER-SYSTEM ANALYSIS

FIGURE 1.-Location and general features of the area of study of the Cambrian-Ordovician aquifer system.

in the system and suggestions for future studies. Detailed discussions of the aquifer system are presented in a series of separate chapters of USGS Professional Paper 1405: chapter A (this report) is the summary, chapter B describes the regional hydrogeologic frame- work and general water quality (Young, in press), chapter $\mathrm{C}$ describes a three-dimensional ground-water flow model of the study area (Mandle and Kontis, in press), chapter D describes the geochemistry (Siegel, 1989), and chapter $\mathrm{E}$ describes a detailed three-dimensional ground- 
water flow model of the Chicago-Milwaukee area (H.L. Young and A.J. MacKenzie, USGS, written commun., 1988).

Other published reports and abstracts of papers presented at scientific meetings by the central staff and by personnel of the subprojects and contractors are listed in the section, "Project Publications."

Data needed for the study were generated from existing files and publications, as well as from newly gathered and interpreted data, from several State agencies, and USGS district offices. A computerized data base was developed (Kontis and Mandle, 1980) to store, edit, and access the data efficiently.

Although extensive geologic data on each rock unit are available, very little information exists on the vertical variation in hydraulic properties, head distribution, or water-quality characteristics within the aquifer system, except in areas where the units crop out. To obtain data on individual hydrogeologic units at various locations, deep test wells were drilled at seven sites (fig. 1). Data on hydraulic conductivity, hydraulic heads, and water quality were obtained from these test wells and from several existing wells by using inflatable hydraulic packers, pressure transducers, and submersible pumps. Two piezometers were installed near each of the two wells in Houston County, Minn. After completion of packer tests on the other five test wells, nests of three or four piezometers separated by grout plugs were installed at different depths in the wells. The piezometers are now part of the USGS's ground-water-level and water-quality monitoring programs. The deepest well, $3,475 \mathrm{ft}$ deep near Zion, Ill., has been described by Nicholas and others (1987).

Water levels were measured or obtained from existing records for the study in the fall of 1980 and spring of 1981 for about 800 deep wells in northern Illinois by the Illinois State Water Survey (Visocky and others, 1985) and for almost 200 wells in southeastern Wisconsin by the USGS. These data were used to prepare potentiometric surface maps for the Cambrian-Ordovician aquifer system in the very important, heavily pumped Chicago-Milwaukee area. The measured heads are mostly from wells open to more than one of the aquifers in the aquifer system and thus generally are a composite of heads in the aquifer system; however, they probably are most representative of heads in the St. Peter-Prairie du Chien-Jordan aquifer.

More than 3,000 chemical analyses of ground water were available from the USGS's WATSTORE (Water Data Storage and Retrieval System) data base, publications of State and Federal agencies, and other scientific reports. Almost 200 ground-water samples were collected during the study to obtain water-chemistry data representative of single aquifers and to obtain special data in particular locations. The new samples were analyzed for the customary major constituents and several trace constituents. In addition, the following special determinations were made: about 120 ratios of the stable isotopes of oxygen, hydrogen, and carbon, 155 analyses of radium and uranium concentration, and 36 carbon- 14 ages.

\section{HYDROGEOLOGY}

\section{GEOLOGIC SETTING}

The present land surface of the northern Midwest is largely the result of Pleistocene continental glaciation that deposited a veneer of unconsolidated glacial drift on the eroded bedrock surface until as recently as $10,000 \mathrm{yr}$ B.P. (years before present), during Wisconsin time. Glaciers advanced and retreated numerous times during the Pleistocene Epoch; the extent of the Wisconsin, Illinoian, and pre-Illinoian glaciations in the area is shown in figure 2 . The topography is formed by a variety of depositional and erosional features in the drift, which generally is 50 to $100 \mathrm{ft}$ thick but is as much as several hundred feet thick in end moraines and buried bedrock valleys. Drift commonly is less than $50 \mathrm{ft}$ thick on some upland areas and is absent from the Driftless Area of southwestern Wisconsin and adjacent areas (fig. 2).

Consolidated sedimentary rocks beneath the drift range in age from Precambrian to Cretaceous (fig. 3). They crop out in generally concentric, arcuate patterns away from the Transcontinental and Wisconsin arches, which are topographically high areas of the Precambrian basement (fig. 4) in northern Minnesota and Wisconsin, respectively. Cambrian and Ordovician rocks also crop out near the Missouri and Mississippi Rivers in eastern and southern Missouri, where they dip downward to the north away from the Ozark uplift - a high on the Precambrian surface in southeastern Missouri. The configuration of the basement surface shows the strongly downwarped character of the structural basins, which also is reflected in the surfaces of most of the overlying sedimentary formations.

The thickness of the sedimentary rocks increases away from the arches toward flanking structural basins: the Forest City basin in southwestern Iowa, the Illinois basin in southeastern Illinois, and the Michigan basin centered on the Lower Peninsula of Michigan. The maximum thickness is about 14,000 and more than 15,000 $\mathrm{ft}$ in the Illinois and Michigan basins, respectively. Figure 5 depicts the top of the Middle Ordovician St. Peter Sandstone, which shows the direct influence of the structural features of the Precambrian basement and is representative of the general configuration of most of the Paleozoic sedimentary strata in the area. 


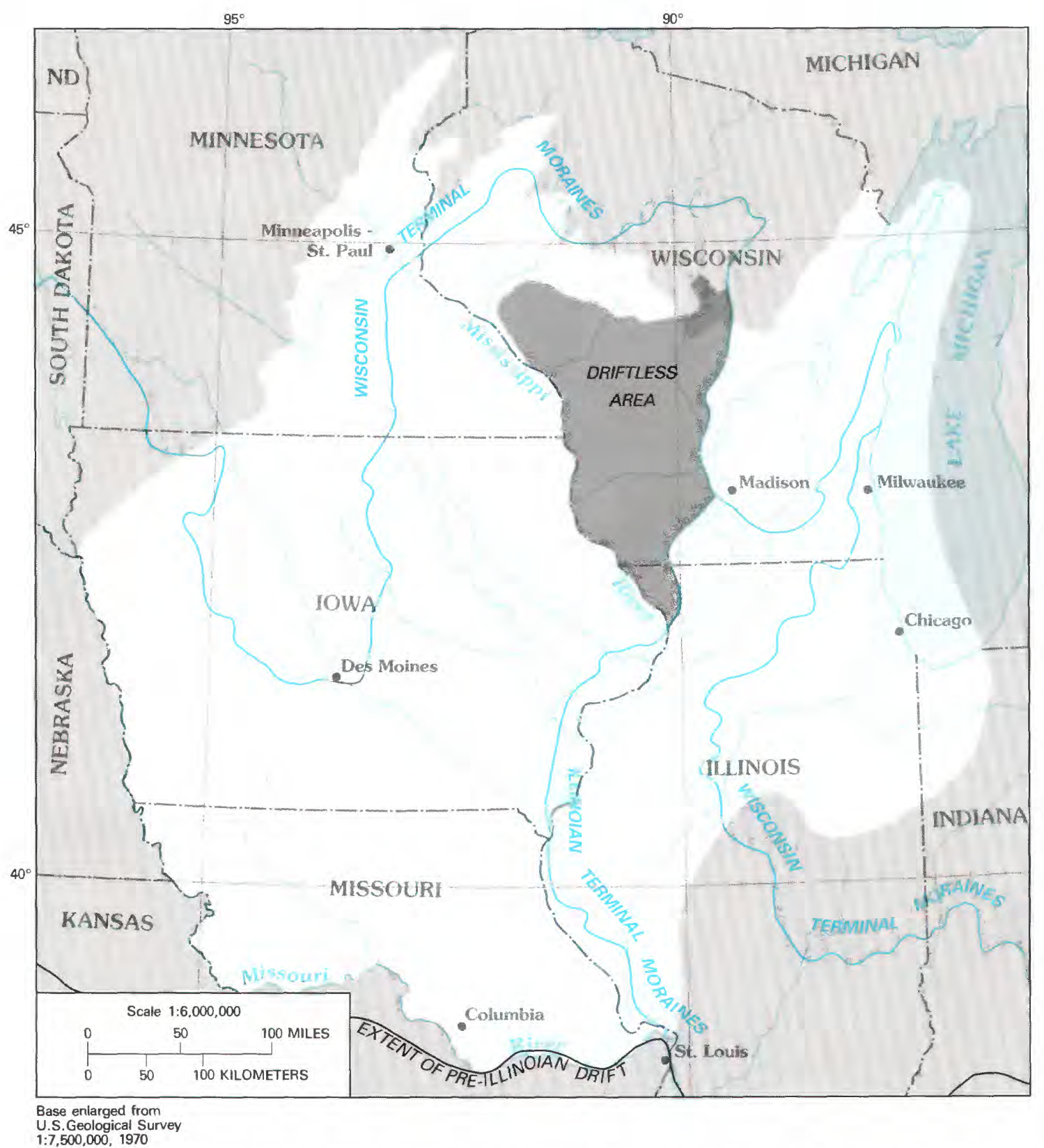

FIGURE 2. - Extent of major glaciations in the northern Midwest during the Pleistocene Epoch. (From Young, in press.)

\section{HYDROGEOLOGIC UNITS}

Rocks in the northern Midwest are regionally divisible into five primary aquifers, each underlain by a less permeable confining unit (table 1). In most of the study area, the uppermost aquifer is the drift aquifer, which contains the water table and consists of unconsolidated glacial drift. The Cretaceous shale and sandstone in western Iowa are not differentiated for this study, but are broadly termed the "Cretaceous aquifer" and locally are included with the drift aquifer as an unconfined aquifer layer in the regional flow model. These watertable aquifers were not included in the present study. However, the Cretaceous Dakota Formation becomes a major aquifer in the Central Midwest RASA study area, which adjoins the present study area on the west and south (Jorgensen and Signor, 1981).

The sequence of rocks ranging in age from Pennsylvanian through Late Devonian, primarily shales and carbonate rocks, is regarded as the uppermost regional confining unit (table 1). This unit, the PennsylvanianMississippian-Devonian confining unit, contains some 


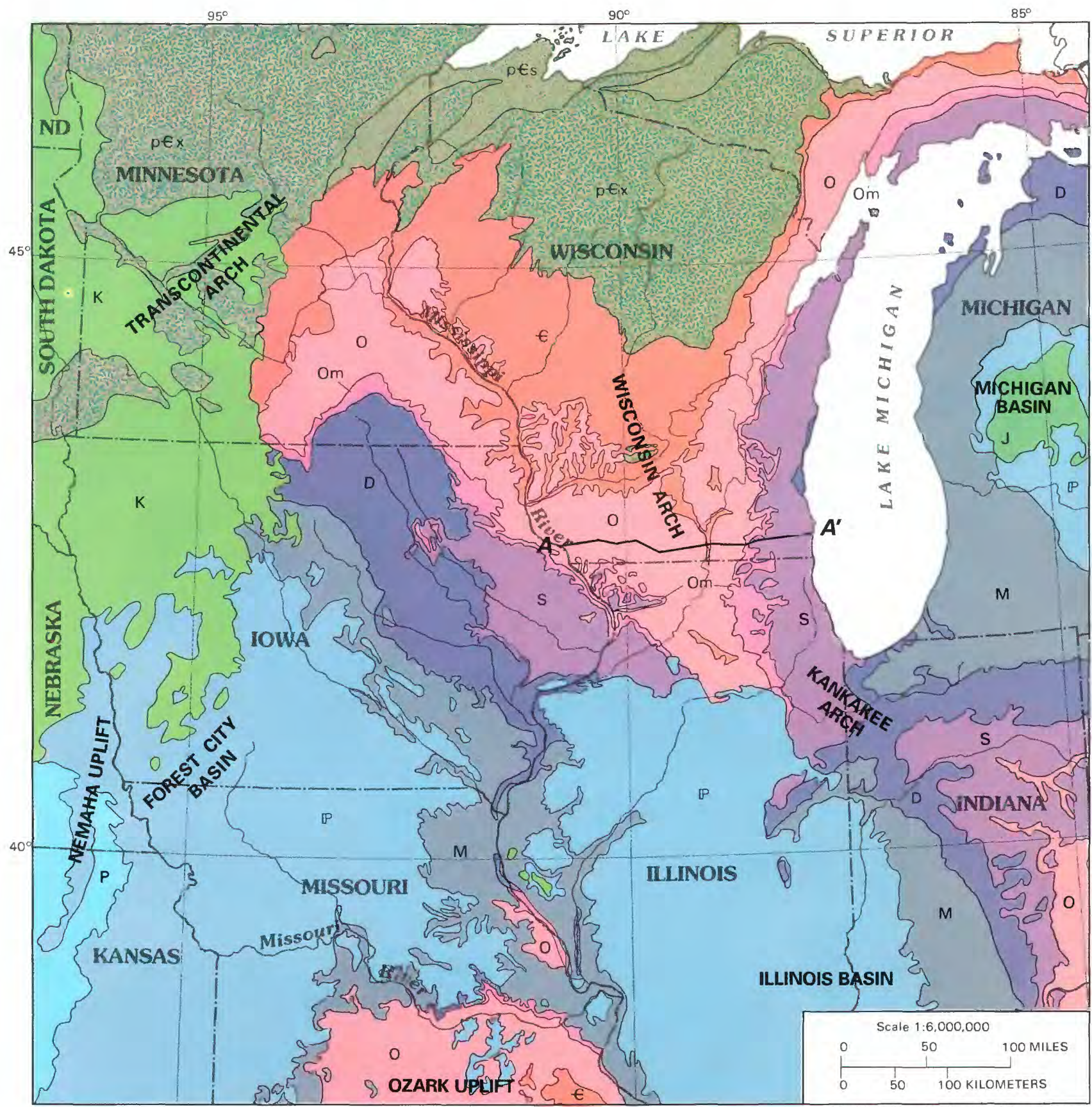

Base enlarged from

1:7.50ological Survey

\section{EXPLANATION}

GEOLOGIC UNITS

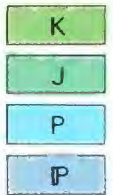

Cretaceous rocks

Jurassic rocks

Permian rocks

Pennsylvanian rocks
Mississippian rocks

Devonian rocks

Silurian rocks

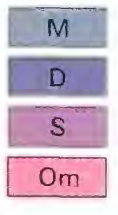

Ordovician Maquoketa Shale CONTACT

$\boldsymbol{A}-\boldsymbol{A}^{\prime}$ LINE OF HYDROGEOLOGIC SECTION - Section shown in figure 11

Ordovician rocks older than the Maquoketa Shale

\section{Cambrian rocks}

Precambrian sandstone

Precambrian crystalline rocks

\section{$p \in x$}

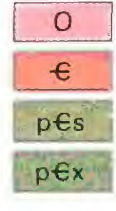




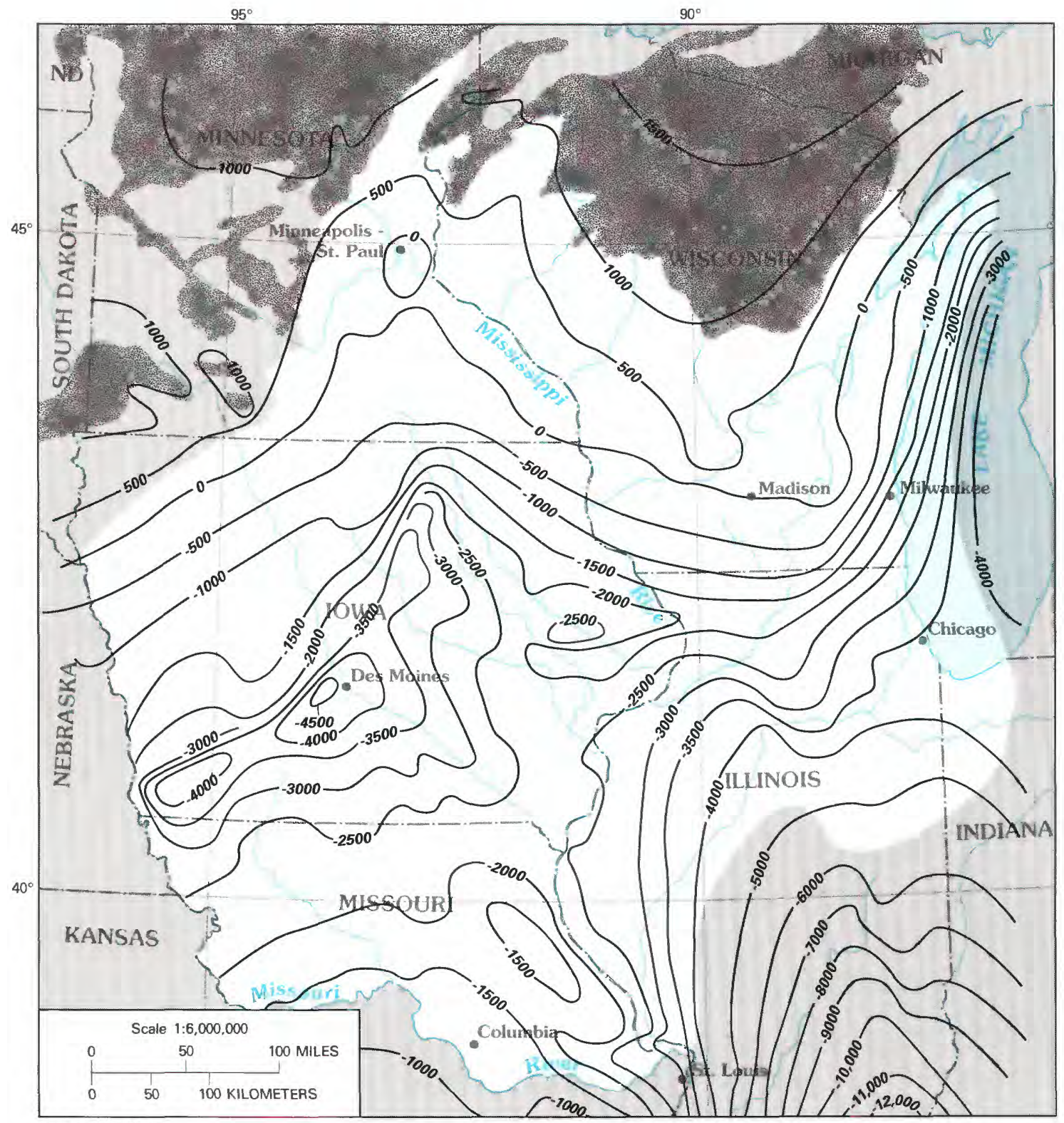

Base enlarged from

$1: 7,500,000,1970$

\section{EXPLANATION}

- 500 - STRUCTURE CONTOUR - Shows altitude of the top of

Precambrian rocks. Contour interval, in feet, is variable.

Datum is sea level

\section{AREA OF OUTCROP OR SUBCROP OF PRECAMBRIAN ROCKS} BENEATH GLACIAL DRIFT

FiguRE 4. - Structural surface of the Precambrian basement in the northern Midwest. (From Young, in press.) 


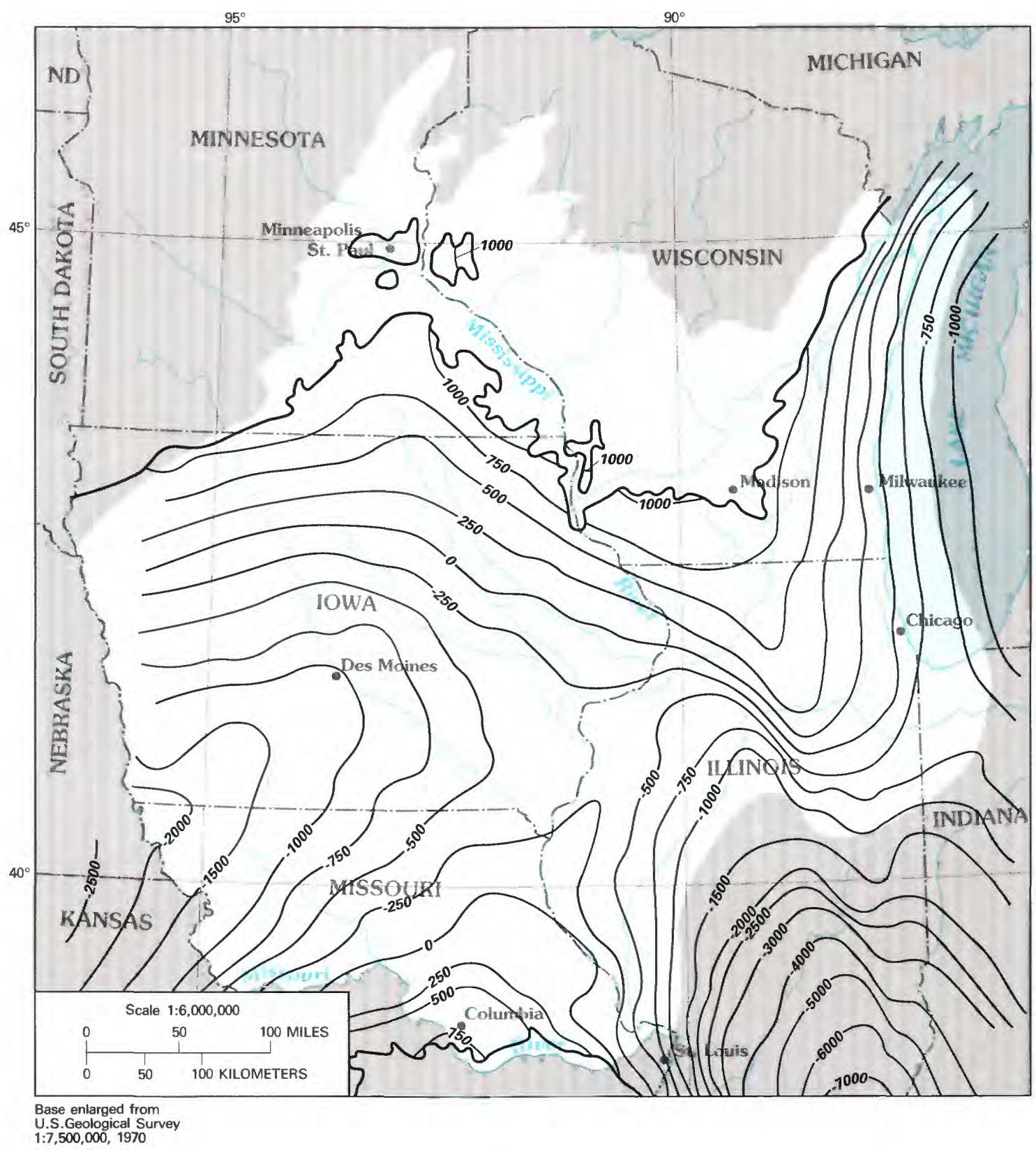

EXPLANATION

- 500 - STRUCTURE CONTOUR - Shows altitude of the top of the St. Peter Sandstone. Includes areas of eroded surface. Contour interval, in feet, is variable. Datum is sea level

EROSIONAL BOUNDARY OF ST. PETER SANDSTONE

Figure 5.-Altitude of the top of the St. Peter Sandstone in the northern Midwest. (From Young, in press.) 
local aquifers that supply small to moderate well yields, but generally it has low permeability compared with the Cambrian-Ordovician aquifer system and can be considered a regional confining unit. This unit forms the bedrock surface in most of the southern and western parts of the study area. It thickens from its erosional edge to more than $3,000 \mathrm{ft}$ in the Illinois and Michigan basins, and is absent in Minnesota, Wisconsin, northeastern Iowa, northern Illinois, and northwestern Indiana.

Rocks of Middle Devonian through Silurian age, mainly dolomite and limestone, form the SilurianDevonian aquifer, which immediately overlies the Cambrian-Ordovician aquifer system except where Silurian and Devonian rocks are absent on the Wisconsin arch. The permeability of this aquifer is highly variable and depends primarily on the extent and degree of intersection of fractures and joints in the rock, and on the subsequent solutional enlargement of these openings by weathering and ground-water movement. This secondary permeability is high in the outcrop and subcrop areas of the aquifer. Reported transmissivities range from 67 to $360,000 \mathrm{ft}^{2} / \mathrm{d}$ (feet squared per day), but more commonly they are less than $500 \mathrm{ft}^{2} / \mathrm{d}$. Except for the outcrop area, the aquifer is overlain and confined by younger rocks of the Pennsylvanian-Mississippian-Devonian confining unit. The Silurian-Devonian aquifer thickens from its erosional edge to more than $1,000 \mathrm{ft}$ in the Illinois and Michigan basins, but generally it is 200 to $500 \mathrm{ft}$ thick in its outcrop areas.

The remaining sedimentary rocks older than Silurian (mostly Cambrian and Ordovician in age) are the main subject of this study. The Cambrian-Ordovician aquifer system consists of three successive pairs of alternating aquifers and overlying confining units (table 1). The hydrogeologic units are named for their dominant stratigraphic components in the northern part of the study area but consist of stratigraphic and hydrologic equivalents in the southern part. The components of the Cambrian-Ordovician aquifer system are defined for this study as follows:

Maquoketa confining unit. - This unit provides the primary confinement to the Cambrian-Ordovician aquifer system. The Maquoketa Shale is the main component of the unit, but where the Maquoketa overlies dolomite and shale of the Galena Dolomite and Decorah, Platteville, and Glenwood Formations, these formations also are an important part of the confining unit. Where the Maquoketa is absent, these formations are more likely to have a higher permeability because of the effects of weathering, and locally they are moderately productive aquifers. In southeastern Minnesota, the Maquoketa Formation is mainly limestone and is included with limestone of the overlying Middle Devonian Cedar Valley Formation - the only younger rock in the area-and the underlying dolomitic limestones of the Dubuque and Galena Formations to form the local upper carbonate aquifer. The Maquoketa confining unit thickens from the north to the south and east. It commonly is 400 to $600 \mathrm{ft}$ thick in eastern Iowa, eastern Wisconsin, and northeastern Illinois (fig. 6).

St. Peter-Prairie du Chien-Jordan aquifer.-This aquifer is an important source of ground water, especially in the western part of the study area, in Iowa and Minnesota. In those States, the aquifer consists of the generally uniform Jordan Sandstone and the hydraulically connected dolomite of the overlying Prairie du Chien Group. The transmissivity of the Jordan aquifer depends on the degree of development of secondary permeability in the dolomite due to fractures and solutional enlargement by weathering. A very large range in transmissivity, from 42 to $33,000 \mathrm{ft}^{2} / \mathrm{d}$, has been reported, but a more common range is about 500 to 5,000 $\mathrm{ft}^{2} / \mathrm{d}$. The aquifer is well confined in most of Iowa, but in much of southeastern Minnesota the rocks are near the surface, are dissected by valleys, and are only partly confined. In Wisconsin, the aquifer subcrops in uplands in the northwest and crops out in the uplands of the Driftless Area in the west and southwest. Because the water table is very deep beneath the ridges, the upper part of the aquifer is unsaturated beneath much of the uplands. In the eastern part of the study area, the aquifer is not as important a source of water because the Jordan Sandstone is not present and the Prairie du Chien is thin or absent owing to pre-St. Peter erosion in much of southern Wisconsin and northern Illinois. In northern Missouri, the aquifer consists of the St. Peter and underlying carbonate equivalents of the Prairie du Chien and Jordan-the Roubidoux Formation and the Gasconade and Eminence Dolomites. The Roubidoux and Gasconade contain some sandstone that makes them productive aquifers.

The aquifer increases in thickness away from the northern eroded edge to more than $1,500 \mathrm{ft}$ in the Illinois basin (fig. 7).

St. Lawrence-Franconia confining unit. - The two formations that form this unit generally are very silty and shaly, fine-grained, poorly sorted, dolomitic sandstones. Although they contribute water locally to some multiaquifer wells, their low permeability and anisotropy make them more important as a regional confining unit. These formations grade laterally southward and eastward into the Potosi and Derby-Doerun Dolomites and the Davis Formation (a shaly, silty dolomite) in Missouri, Illinois, and Indiana. The unit thickens southward much as the Maquoketa confining unit does (fig. 6). It generally is about 100 to $200 \mathrm{ft}$ thick in the northern, freshwater part of the aquifer system, but is less than $100 \mathrm{ft}$ thick in most of Wisconsin. 
TABLE 1.-Hydrogeologic-unit nomenclature used in the study of the Cambrian-Ordovician aquifer system [Aquifer units are shaded. Gp, Group; Fm, Formation; Ss, Sandstone; Ls, Limestone; Dol, Dolomite. From Young, in press]

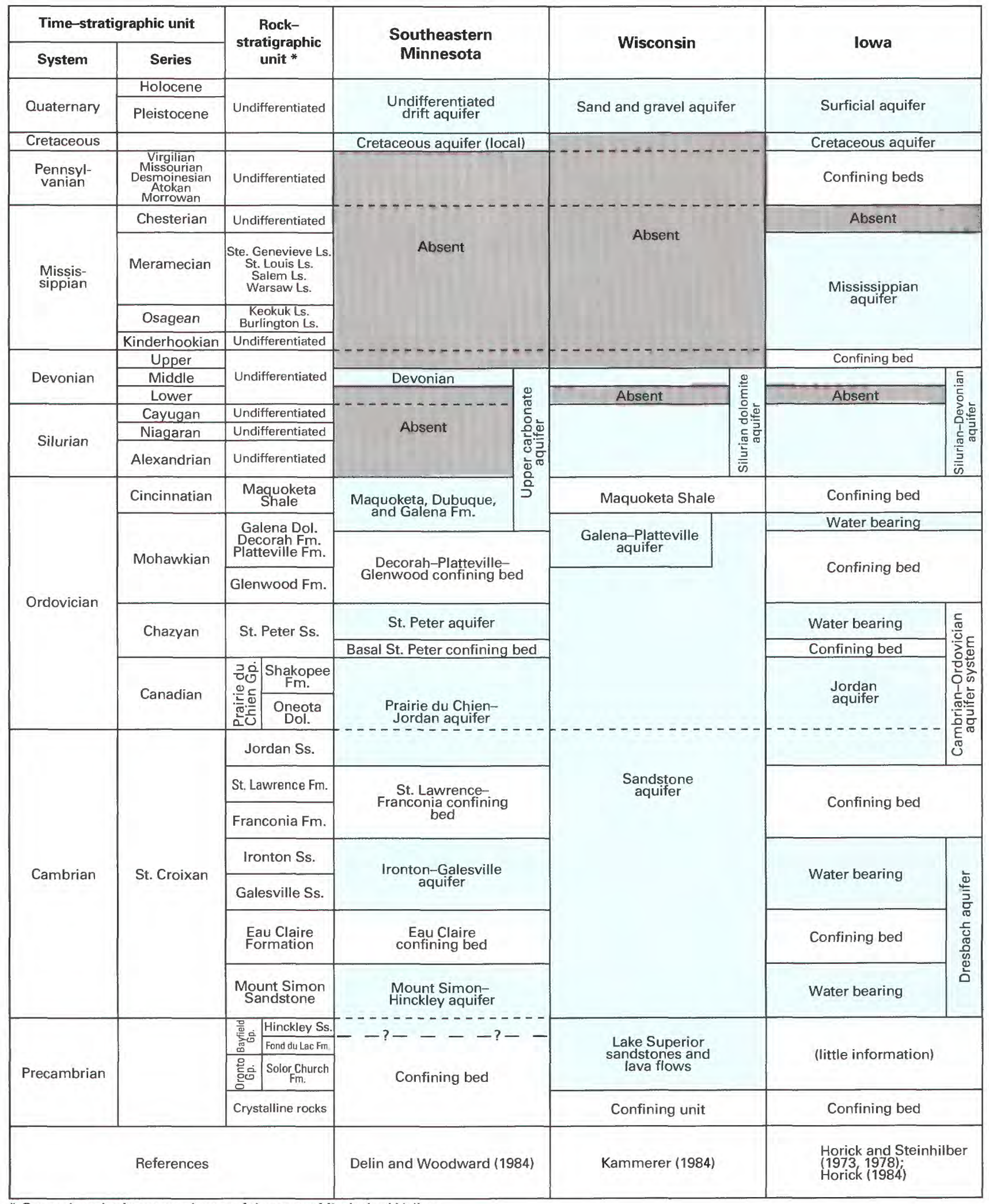

\footnotetext{
* General geologic nomenclature of the upper Mississippi Valley
} 
TABLE 1.-Hydrogeologic-unit nomenclature used in the study of the Cambrian-Ordovician aquifer system-Continued [Aquifer units are shaded. Gp, Group; Fm, Formation; Ss, Sandstone; Ls, Limestone; Dol, Dolomite. From Young, in press]

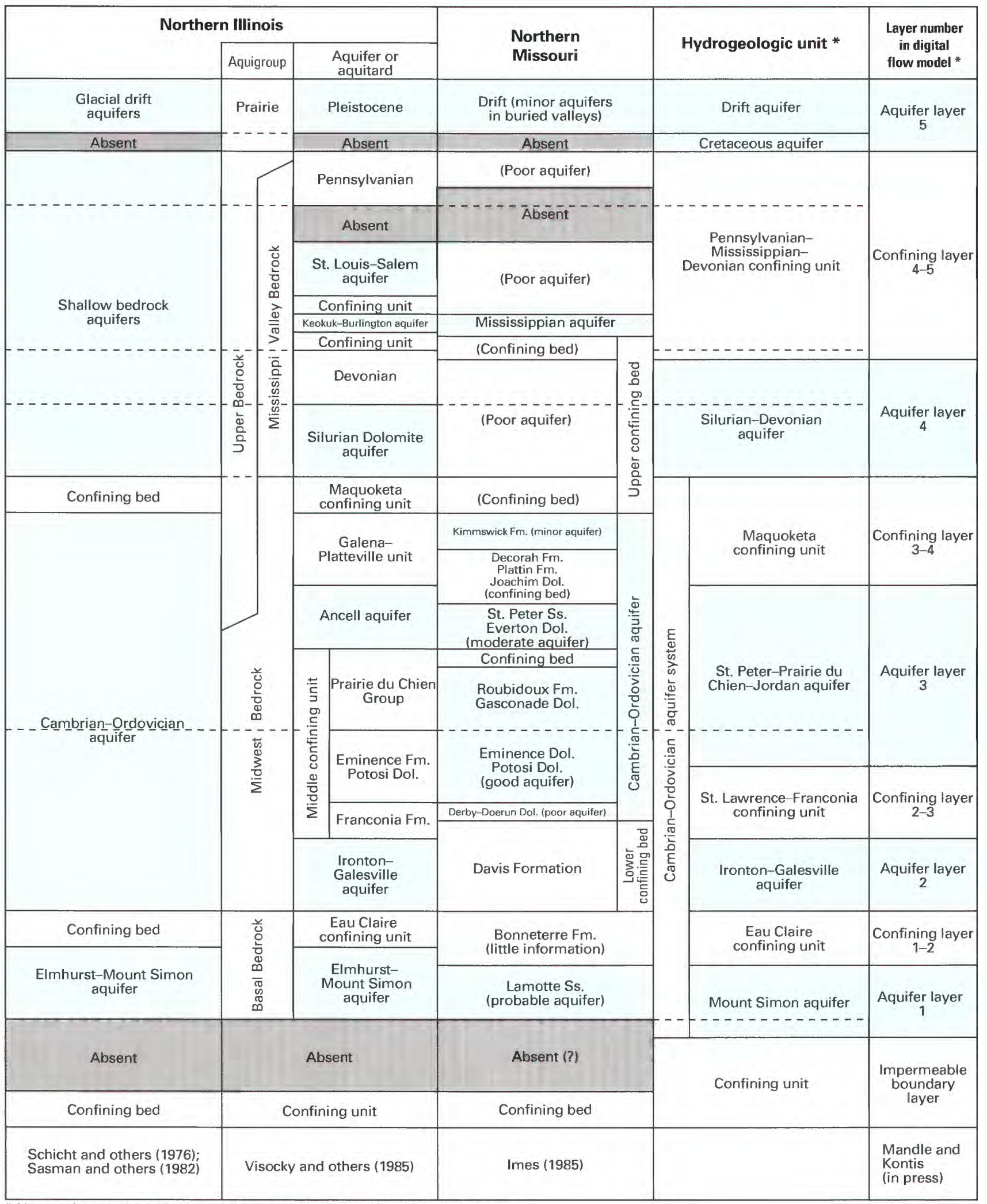

\footnotetext{
* Nomenclature of the Northern Midwest Regional Aquifer-System Analysis
} 


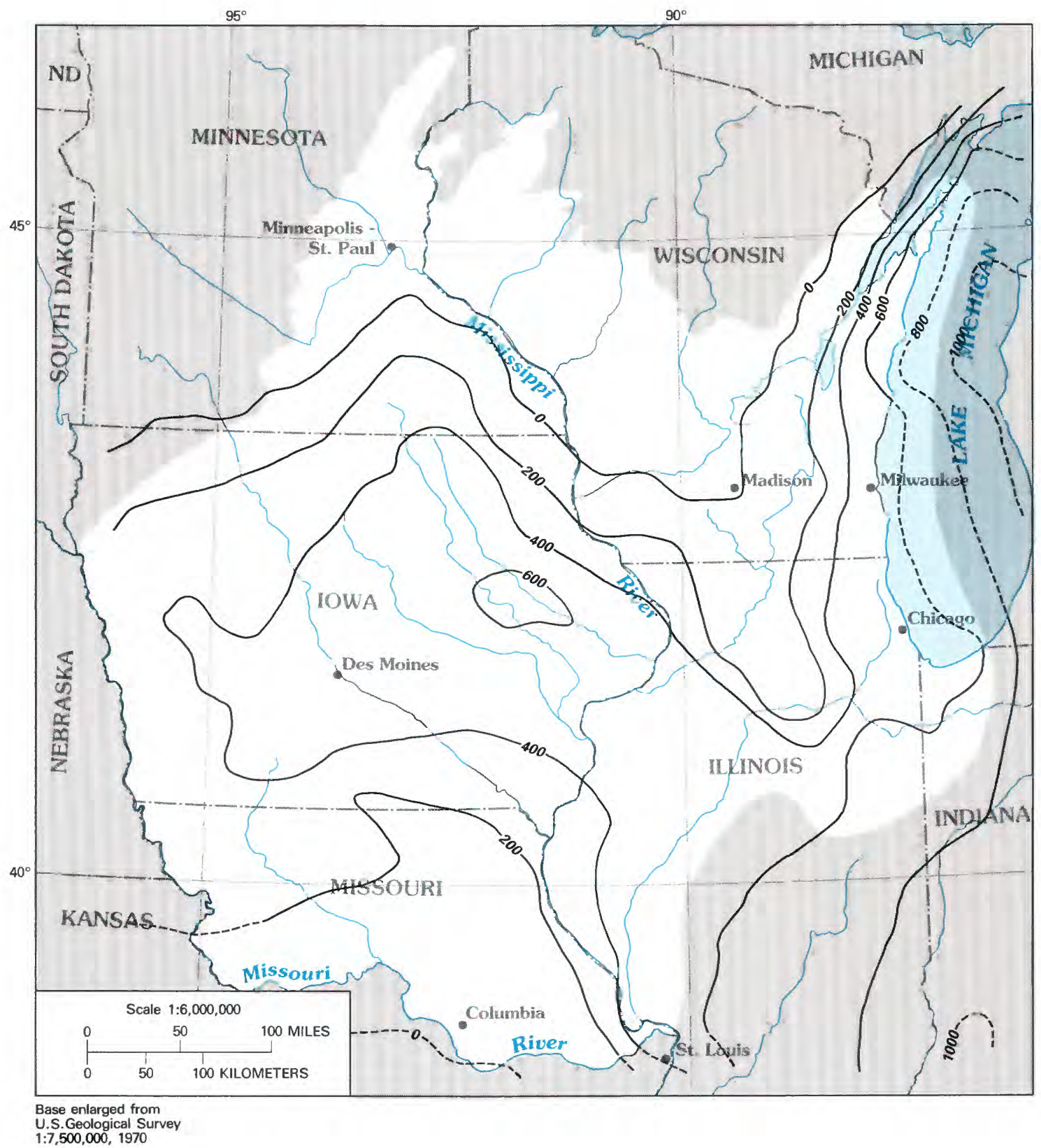

EXPLANATION

-600--- LINE OF EQUAL THICKNESS OF THE MAQUOKETA CONFINING UNIT - Dashed where inferred. Interval 200 feet

FIgure 6. - Thickness of the Maquoketa confining unit in the northern Midwest. (From Mandle and Kontis, in press.)

Ironton-Galesville aquifer.-This aquifer is the most productive unit of the Cambrian-Ordovician aquifer system in the east-central part of the study area, in northeastern Illinois and southeastern Wisconsin. It consists of moderately well sorted quartzose sandstones. Reported values of transmissivity for the Ironton-
Galesville aquifer range from 71 to $11,000 \mathrm{ft}^{2} / \mathrm{d}$, but most of the values range from the upper hundreds to about $3,000 \mathrm{ft}^{2} / \mathrm{d}$-an indication of the overall uniformity of the aquifer. The aquifer thickens southward from its eroded edge, reaching maximums of 150 to $200 \mathrm{ft}$ in northwestern and east-central Illinois, but its thickness generally is 


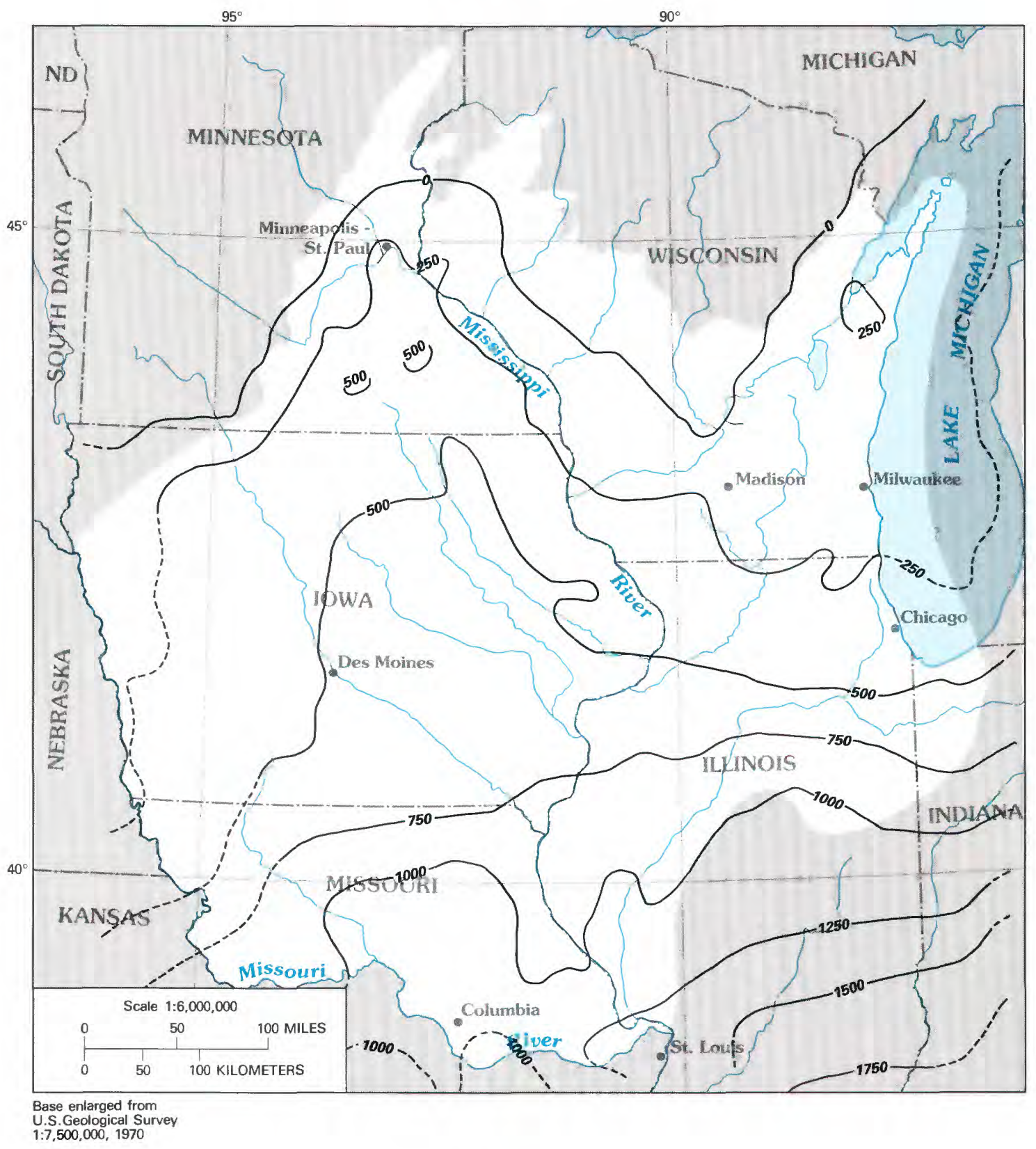

EXPLANATION

- 500--- LINE OF EQUAL THICKNESS OF THE ST. PETER-PRAIRIE DU CHIENJORDAN AQUIFER - Dashed where inferred. Interval 250 feet

Figure 7.-Thickness of the St. Peter-Prairie du Chien-Jordan aquifer in the northern Midwest. (From Mandle and Kontis, in press.)

50 to $150 \mathrm{ft}$ (fig. 8). The aquifer terminates farther southward as the sandstones grade into carbonate rocks of the Davis Formation in central Iowa, Missouri, southern Illinois, and north-central Indiana.
In eastern Wisconsin north of Milwaukee, the rock units that make up the Elk Mound Group of Ostrom (1967), the Ironton and Galesville Sandstone Members in Ostrom's Wonewoc Sandstone and the Eau Claire and 


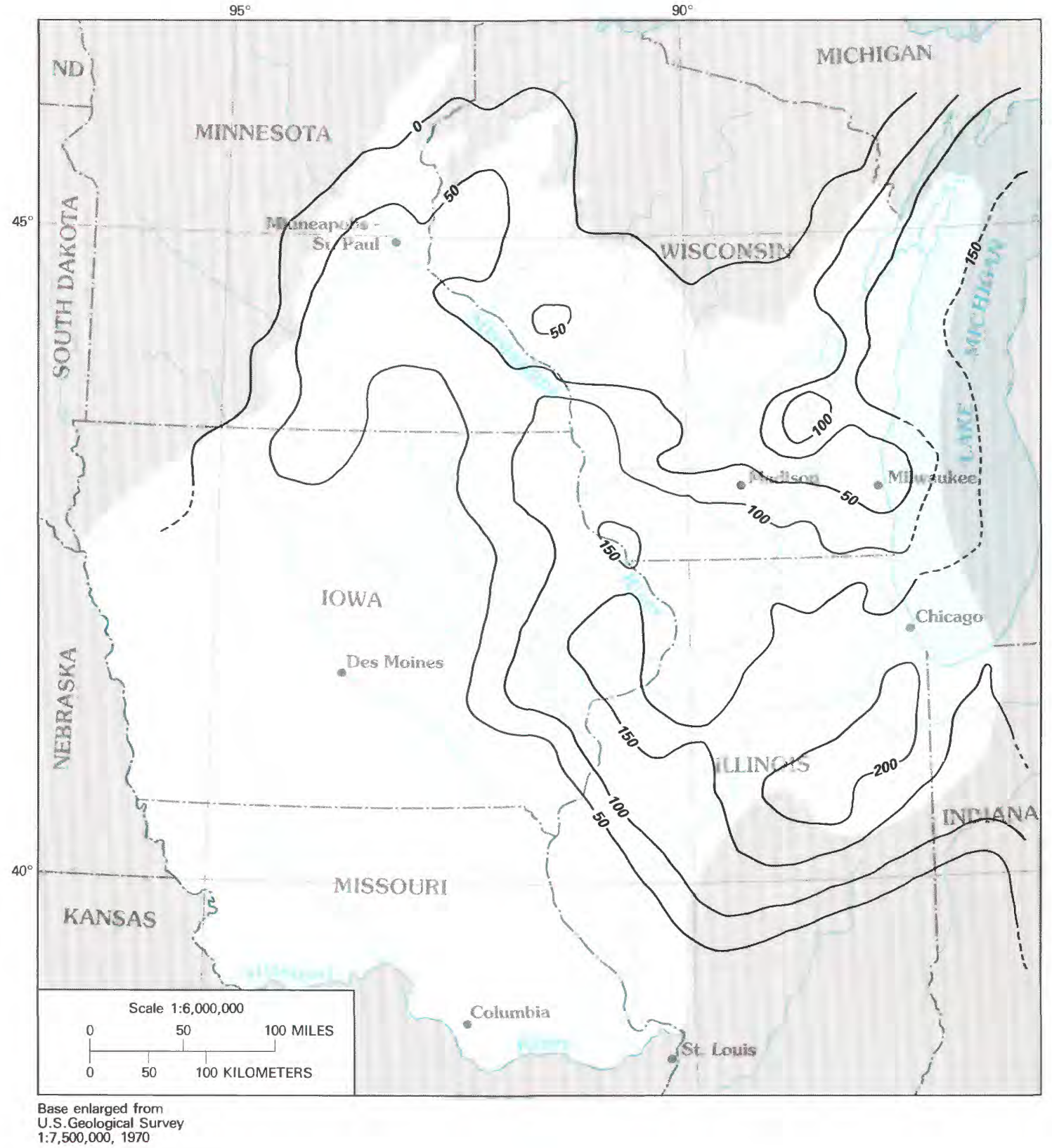

EXPLANATION

-100--- LINE OF EQUAL THICKNESS OF THE IRONTON-GALESVILLE AQUIFER - Dashed where inferred. Interval 50 feet

FIGURE 8. - Thickness of the Ironton-Galesville aquifer in the northern Midwest. (From Mandle and Kontis, in press.)

Mount Simon Sandstones generally cannot be differentiated in well cuttings and geophysical logs. Thus, the Ironton-Galesville is not identified there as a separate aquifer.

Eau Claire confining unit.-This is an important confining unit throughout much of the study area. Its effectiveness as a confining unit, which is directly dependent on the proportion of relatively impermeable shale, siltstone, and dolomite to sandstone, generally increases toward the south. The confining unit is not identifiable north of Milwaukee, where the members of the Elk Mound Group generally cannot be differentiated. 
Dolomite content increases southward and westward, where the Eau Claire Formation is replaced laterally by the Bonneterre Formation in northwestern Missouri and western Iowa. In northern Illinois, the confining unit consists of the two uppermost members of the Eau Claire Formation, as the latter is defined by the Illinois State Geological Survey (Willman and others, 1975). From 50 to $125 \mathrm{ft}$ of fine-grained sediment usually is evident on borehole gamma logs and geologic logs of well cuttings from extreme northern Illinois, southern Wisconsin, and southeastern Minnesota. The overall thickness of the unit increases steadily from its northern outcrop area to about 200 to $300 \mathrm{ft}$ in central Iowa and north-central Illinois and to more than $750 \mathrm{ft}$ in the Illinois basin.

Mount Simon aquifer. - This is the most extensive aquifer in the northern Midwest because of its basal position on the Precambrian surface. It consists mainly of the Mount Simon Sandstone in the north and its equivalent in northern Missouri, the Lamotte Sandstone. However, the underlying Precambrian Hinckley Sandstone is included in Minnesota, and the overlying Elmhurst Sandstone Member of the Eau Claire Formation as used in northern Illinois is also included (table 1). The aquifer is dominantly sandstone that is poorly to moderately well sorted. It contains variable amounts of fine-grained sediment, including zones of lenticular shale beds, which are prominent a few hundred feet below the top of the Mount Simon in southeastern Wisconsin, northeastern Illinois, and northwestern Indiana. A zone as much as 300 to $500 \mathrm{ft}$ thick contains abundant interbedded red shale and forms a local confining unit within the Mount Simon. The hydraulic conductivity of the aquifer is somewhat low, especially where deeply buried and confined; however, reported transmissivity values range from 270 to $9,400 \mathrm{ft}^{2} / \mathrm{d}$ because of the great thickness of the aquifer.

The Mount Simon aquifer crops out or subcrops beneath glacial drift in large areas of northern Wisconsin and eastern Minnesota and generally dips smoothly to the south and east toward the structural basins. Its top is about 2,500 ft below sea level in the Forest City basin and along the northern perimeter of the Illinois basin in north-central Illinois, but its base in these areas is, respectively, about 2,700 and $4,500 \mathrm{ft}$ below sea level. This difference in the depth to the base is due to the much greater depth of the Precambrian surface in the Illinois basin than in other areas. The top of the aquifer is more than $12,000 \mathrm{ft}$ below sea level in the center of the Illinois and Michigan basins.

The great thickness of the aquifer (fig. 9) in Illinois (more than 2,500 $\mathrm{ft}$ just south of Chicago), western Indiana, and extreme southeastern Wisconsin is not, and generally cannot be, used for water supply for several reasons. First, adequate yields generally are obtained from multiaquifer wells that penetrate only the overlying Cambrian and Ordovician rocks, or that penetrate the Mount Simon aquifer only a few hundred feet. Second, water in the lower part of the aquifer is saline near Lake Michigan, and water in the entire aquifer is progressively more saline toward the Illinois and Michigan basins, where brines are present. The aquifer also is not used extensively in Iowa for essentially the same reasons: In the western and southern parts of the State, it is deeply buried and contains saline water.

The nearly impermeable crystalline rocks of the Precambrian basement beneath the Cambrian-Ordovician aquifer system are a very effective confining unit, and their upper surface marks the practical lower limit of ground-water availability.

\section{RECHARGE, GROUND-WATER MOVEMENT, AND DISCHARGE}

The concept of multiple flow systems of different areal and subsurface extent (Toth, 1962; Freeze and Witherspoon, 1967) applies to ground-water flow in the northern Midwest. The flow systems, which are driven by the hydraulic head at the water table (fig. 10), range from local to intermediate to regional in scope. These conceptual flow systems are illustrated in figure 11 as generalized predevelopment flow paths along an east-west hydrogeologic section across southern Wisconsin. The water table is used for the top of the section.

The flow paths in figure 11 are highly diagrammatic and should not be construed as representative of exact conditions. They are based on the premise that the section is parallel to the direction of most ground-water flow. This generally is true in the eastern half of the section, but is not true in the western half. Thus, the flow paths shown in the west are idealized, especially in the deep intermediate and regional flow systems.

Development of the ground water in the northern Midwest generally has caused little change in the altitude of the water table and in flow directions in local systems. Thus, the average present-day water-table conditions are similar to predevelopment conditions. However, large withdrawals from confined zones of intermediate and regional flow systems have caused major head declines and subsequent changes in direction of flow. These changes are discussed later in the report.

Most local flow systems are less than a few miles in length from areas of recharge to areas of discharge (see fig. 11). Local systems represent most of the flow within the water-table aquifers, which in turn account for a large part of the overall volume of ground-water recharge and discharge in the northern Midwest. Most of this flow does not enter the bedrock aquifers, or penetrates only to shallow depths, and discharges from glacial 


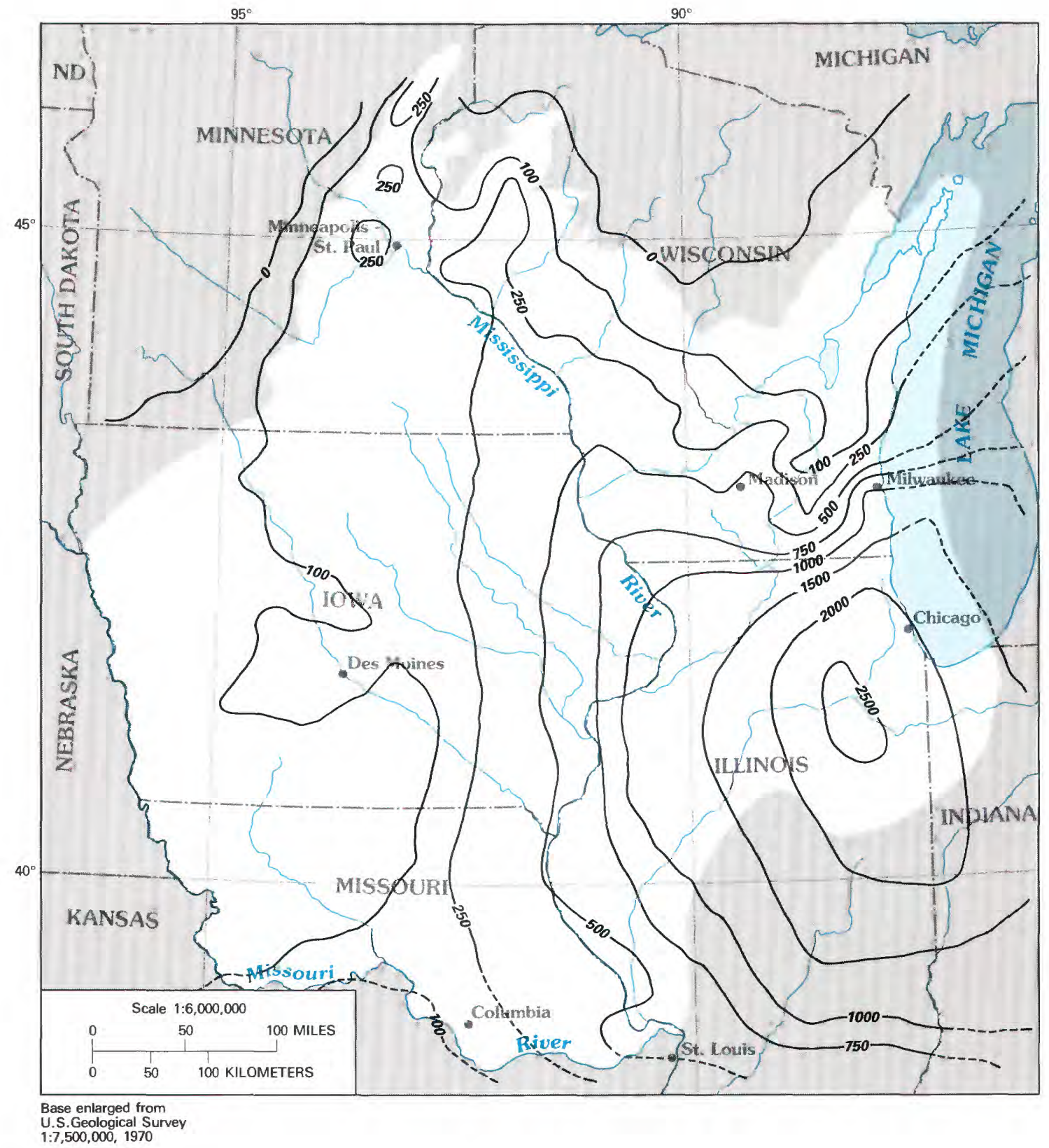

\section{EXPLANATION}

-500--- LINE OF EQUAL THICKNESS OF THE MOUNT SIMON AQUIFER -

Dashed where inferred. Interval, in feet, is variable

FIGURE 9.-Thickness of the Mount Simon aquifer in the northern Midwest. (From Mandle and Kontis, in press.)

drift into surface-water bodies or is lost by evapotranspiration. Where the glacial drift is thin or absent, notably in the Driftless Area (fig. 2) of southwestern Wisconsin and adjacent uplands along the Mississippi River, local flow systems also are present in the uppermost bedrock. The depth to the water table commonly is less than $50 \mathrm{ft}$ in most of the study area, but the water table is 200 to $300 \mathrm{ft}$ deep beneath the highest ridges in the Driftless Area. Shallower, perched ground water is present beneath the ridges where low-permeability rocks restrict downward percolation of water through the thick unsaturated zone. 


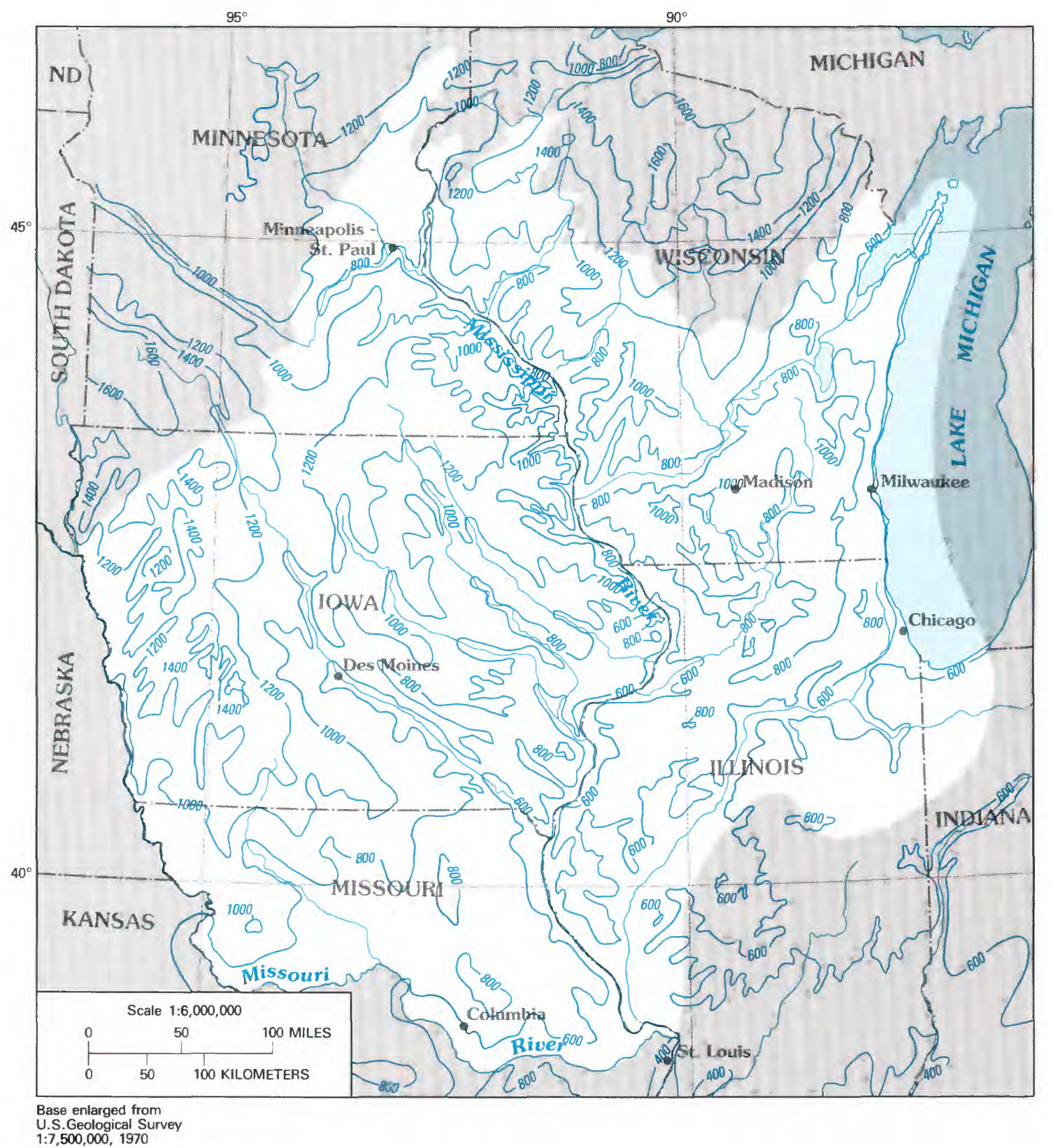

\section{EXPLANATION}

- 800 - WATER-TABLE CONTOUR - Shows altitude of the water table, 1980. Contour interval 200 feet. Datum is sea level

FIGURE 10.-Generalized water table and major surface-water drainage network in the northern Midwest. (From Young, in press.)

Ground-water movement in most of the rest of the bedrock aquifers occurs in intermediate or regional flow systems, where flow paths are deeper and traverse much longer distances from recharge areas to discharge areas and movement is slow. The general patterns of prede- velopment regional ground-water flow within the Cambrian-Ordovician aquifer system are illustrated by the potentiometric surface map for the St. Peter-Prairie du Chien-Jordan aquifer (fig. 12). The map is based on water levels in the earliest wells, generally constructed 

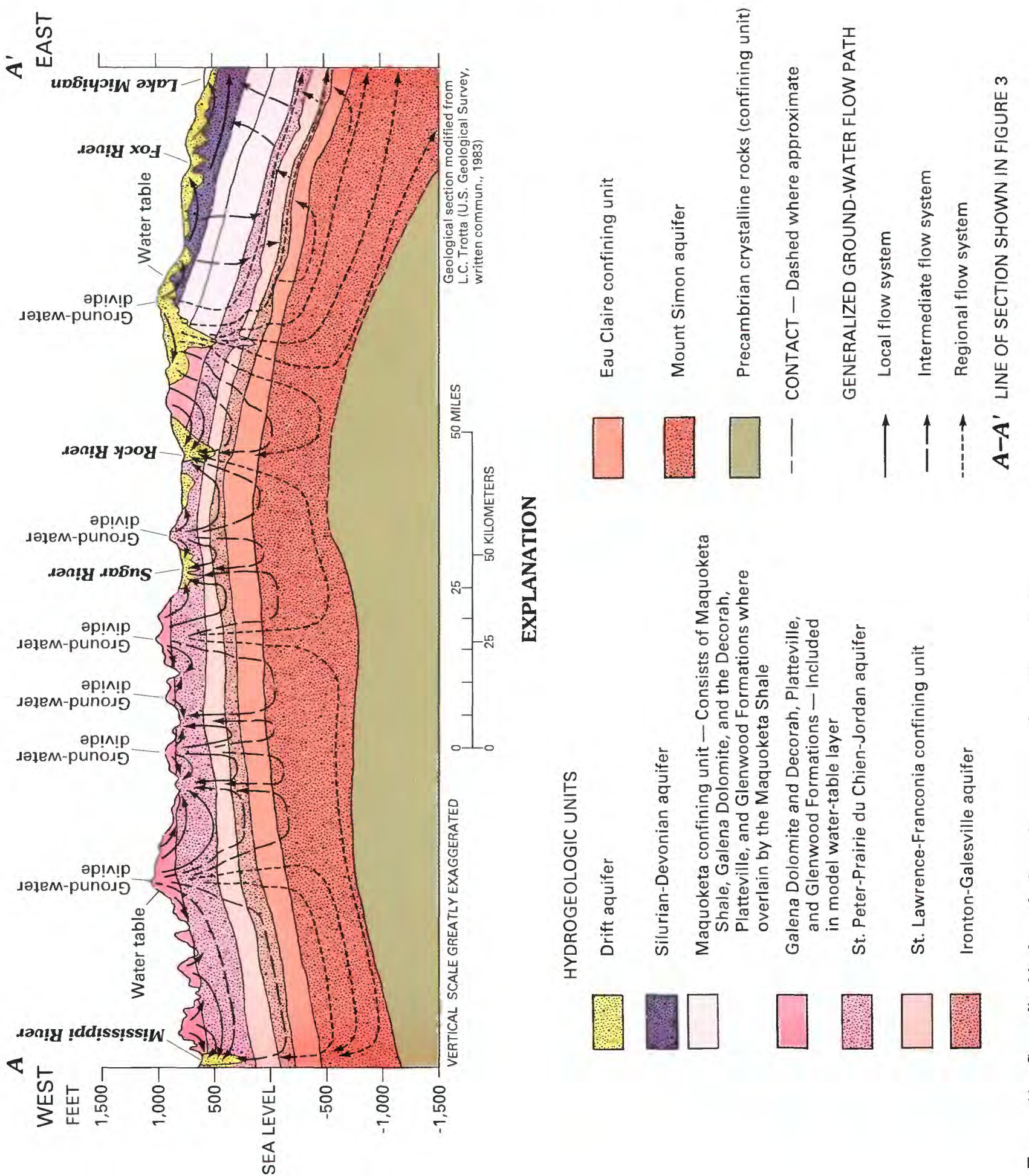

孞

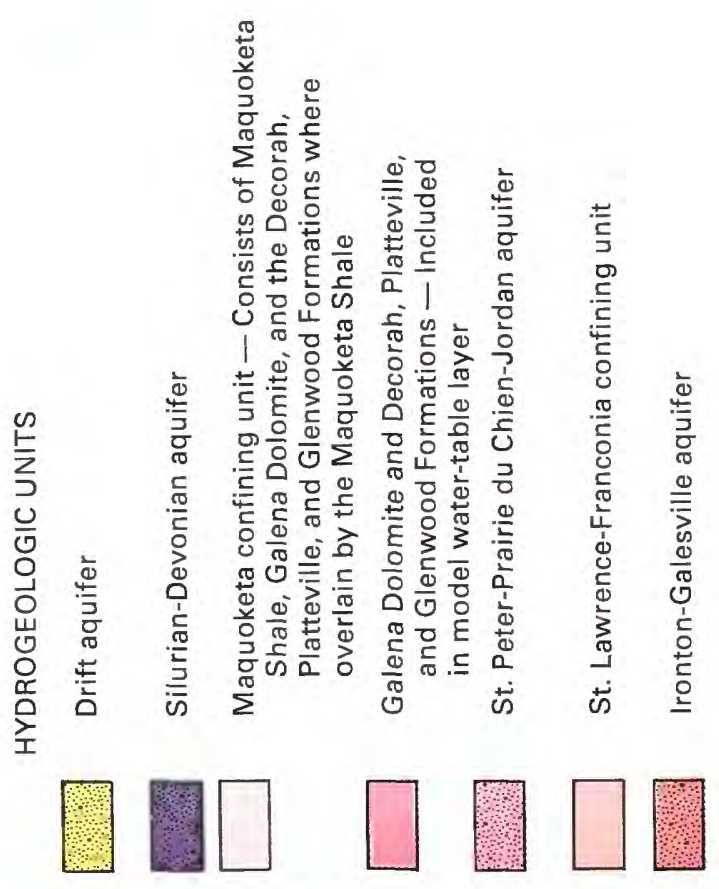

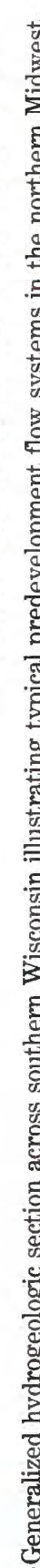




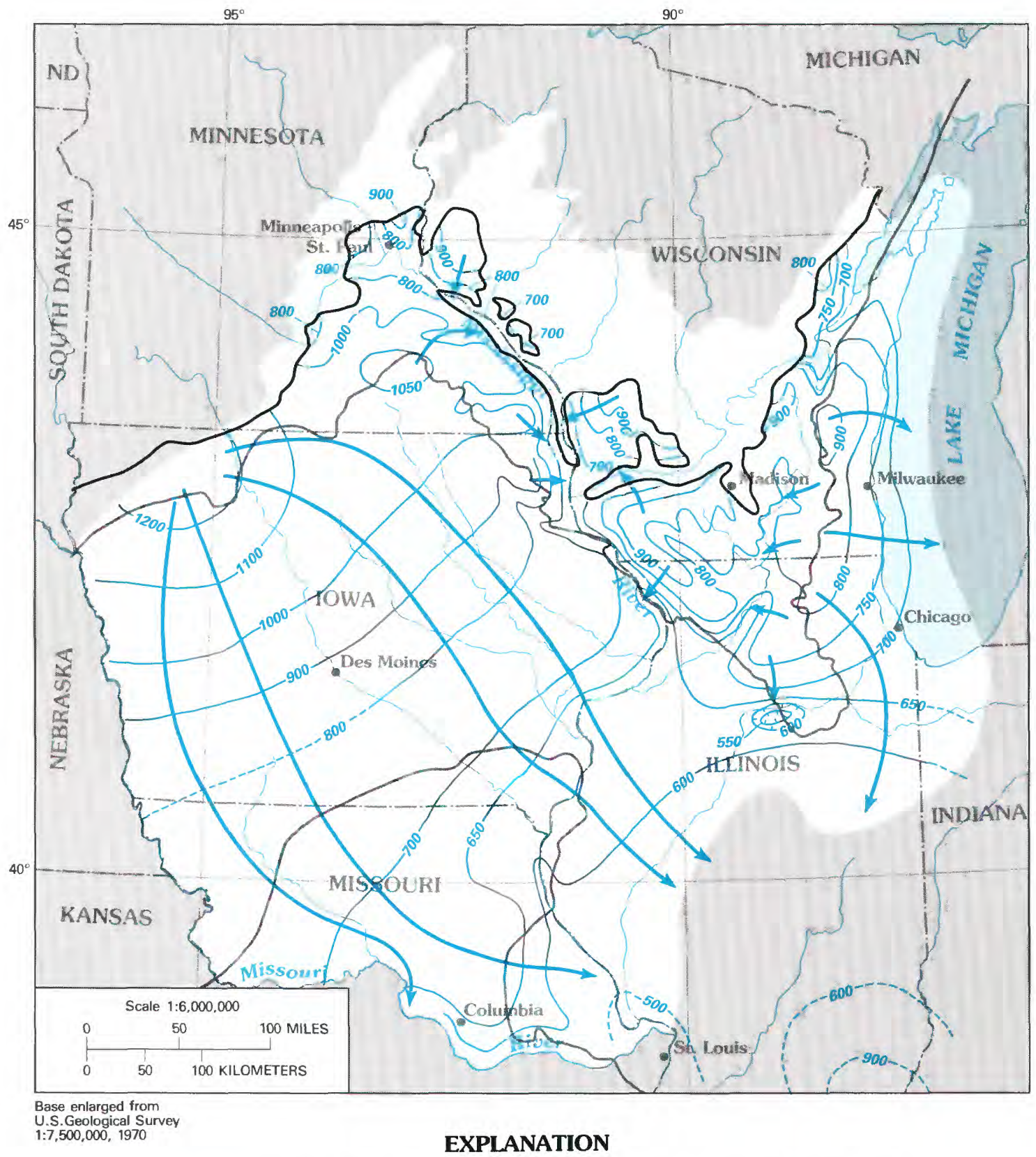
- 500-- POTENTIOMETRIC CONTOUR - Shows approximate altitude of the predevolpment potentiometric surface in the late 1800's for the St. Peter-Prairie du Chien-Jordan aquifer. Hachures indicate area of lower head. Dashed where inferred. Contour interval, in feet, is variable. Datum is sea level

\section{$\longrightarrow$ GENERALIZED DIRECTION OF GROUND-WATER FLOW}

\section{AQUIFER BOUNDARY}

BOUNDARY OF MAQUOKETA SHALE

FIGURE 12. - Approximate predevelopment potentiometric surface for the St. Peter-Prairie du Chien-Jordan aquifer in the northern Midwest. (Modified from Young, in press.) 
in the late 1800 's. The major areas of recharge to regional flow in the aquifer system were in the unconfined, interbasin highlands in northwestern Iowa; southeastern Minnesota; western, southern, and eastern Wisconsin; and northern Illinois. Although the flow rates were small, a significant volume of recharge also leaked downward from the water table through the Maquoketa confining unit where the water table was higher than the head in the Cambrian-Ordovician aquifer system.

Downward flow of ground water in recharge areas is impeded, in general, by zones of lower vertical hydraulic conductivity and, in particular, by confining units. Hydraulic head is lost with increasing depth along downward flow paths in recharge areas. This decline in head was observed in several packer tests during the study in areas of direct recharge from glacial drift to the Cambrian-Ordovician aquifer system. In upland areas of western Wisconsin and near the Mississippi River in southeastern Minnesota, the heads measured in the St. Peter-Prairie du Chien-Jordan aquifer were 200 to $245 \mathrm{ft}$ higher than the heads in the deeper Ironton-Galesville aquifer. The head in the Mount Simon aquifer was 95 to $135 \mathrm{ft}$ lower than the head in the Galena-Platteville unit in wells tested in the recharge area west of Milwaukee. Head losses with depth decreased along the flow paths away from the recharge areas as the water-table altitude decreased. Ultimately, the head gradient reversed at some distance from the recharge area where the water table was lower than the head beneath the Maquoketa confining unit and flow was upward from the CambrianOrdovician aquifer system.

Ground water in most of the Cambrian-Ordovician aquifer system is confined and, prior to development, moved laterally away from the recharge areas, either toward regional discharge areas, the major river valleys and Lake Michigan, or downdip toward the structural basins. Lake Michigan, however, is completely underlain by Silurian and younger rocks; thus, upward flow from the aquifer system was controlled by the Maquoketa confining unit. The lake did not receive direct discharge from the Cambrian-Ordovician aquifer system but, rather, from the Silurian-Devonian aquifer, only a small part of which was derived from upward leakage across the Maquoketa confining unit. The longest flow paths in the Cambrian-Ordovician aquifer system originated in the recharge areas of northwestern Iowa and extended southeastward as much as $400 \mathrm{mi}$ (miles) toward the Illinois basin or to the Mississippi and Missouri River valleys near their confluence (fig. 12).

Other major patterns of confined flow in the CambrianOrdovician aquifer system consisted of the dominantly horizontal flow from eastern Wisconsin eastward to the Michigan basin (see fig. 3) and from northeastern Illinois southward to the Illinois basin. The composite predevel- opment head in the aquifer system at Chicago and Milwaukee was estimated to be 130 and $186 \mathrm{ft}$ above Lake Michigan (580 ft above sea level) by Suter and others (1959) and Weidman and Schultz (1915), respectively. Packer tests during this study showed only slight head differences between aquifers in the confined parts of the aquifer system in eastern Wisconsin, northeastern Illinois, and northwestern Indiana. Although these heads are probably equalized in part because of large regional drawdown from heavy pumping of wells in the Cambrian-Ordovician aquifers, simulation with the regional flow model also indicates little difference in predevelopment heads. Water-level measurements from packer tests and deep piezometers installed in the 3,475ft-deep test well at Zion, Ill., show that the present head is about $50 \mathrm{ft}$ higher beneath a 500 -ft-thick zone of interbedded shales that begins about $100 \mathrm{ft}$ below the top of the Mount Simon (Nicholas and others, 1987). This higher head within the Mount Simon probably is a remnant of the predevelopment artesian conditions that prevailed within the entire Cambrian-Ordovician aquifer system near the western shore of Lake Michigan.

Regional predevelopment ground-water discharge from the Cambrian-Ordovician aquifer system occurred mainly as slow, upward leakage from the confined aquifers along flow paths toward the structural basins. Very saline water around the basins and brines within the basins restricted regional flow of ground water into the basins, thereby forcing the confined water upward through overlying rocks. Head in the confined aquifers gradually dissipates because of this upward leakage and because of frictional losses along the flow paths into the basins and upward through confining units. Frictional losses eventually may decrease the head until no appreciable upward flow occurs from deep within the basins except through fractures (Bond, 1972). Ground water in intermediate flow systems discharged upward from the Cambrian-Ordovician aquifers to the major river valleys, such as the Mississippi River valley in the Twin Cities artesian basin.

\section{GEOCHEMISTRY OF WATER}

Ground water in the Cambrian-Ordovician aquifer system in the northern Midwest is characterized by a large range of mineralization and chemical types, but its quality is good and suitable for most uses in most of the study area. Dissolved-solids concentrations generally are lowest in the recharge areas in the northern and central parts of the area and are highest in the structural basins to the south and east. The water generally is hard.

Investigation of the evolution of the chemical character of ground water in the Cambrian-Ordovician aquifer 
system is complicated because of numerous geochemical processes, which, through geologic time, have produced the present water quality. Ground water in the deepest parts of the aquifer system has moved long distances from the recharge areas, and its quality is a product of its very long time of contact with the rocks, and of the character of the sediment and minerals that form the rocks, in addition to other processes that are described later. Interpretation of the present chemical character of the ground water in terms of hydrochemical facies and other water-quality characteristics indicates some residual effects of the large-scale continental glaciations during the Pleistocene on ground-water quality in the northern Midwest. For example, there is evidence from stable isotope ratios that ground water in much of the deeper part of the Cambrian-Ordovician aquifer system represents recharge of meltwater from Pleistocene glaciers.

Detailed evaluation of water quality in the CambrianOrdovician aquifer system is limited by the availability of analyses that represent specific aquifers, because many wells are finished in more than one aquifer. Water quality generally is similar in all units of the aquifer system in the large areas of mainly unconfined conditions in Minnesota, Wisconsin, northeastern Iowa, and northcentral Illinois; therefore, this study also has included analyses of ground water from multiaquifer wells in those areas. In the confined areas in Iowa, Missouri, Illinois, and eastern Wisconsin, water-quality data for a single aquifer are available mainly for the St. PeterPrairie du Chien-Jordan aquifer; thus, most of the following discussion and presentation of areal distribution of water-quality properties in those areas pertains to this aquifer.

\section{GENERAL CHEMICAL CHARACTERISTICS RELATED TO THE HYDROLOGIC SYSTEM}

Ground water in the Cambrian-Ordovician aquifer system contains all the major ions that commonly dominate the water quality of natural waters: calcium, magnesium, and sodium cations and bicarbonate, sulfate, and chloride anions. The distribution of sulfate (fig. 13) is representative of the general pattern of distribution of the other major ions and dissolved solids in the aquifer system. The areal distribution and predominance of these ions were used (Siegel, 1989) to classify the water in the aquifer system into hydrochemical facies according to the method of Back (1966).

\section{HYDROCHEMICAL FACIES}

Most ground water, especially in the unconfined areas, is a calcium magnesium bicarbonate type (fig. 14), derived mainly from dissolution of carbonate minerals in calcareous glacial drift by carbon dioxide-enriched recharge water. As previously stated, water quality tends to be similar in individual units of the aquifer system in the unconfined areas and, logically, is very similar to that in overlying water-table aquifers. Where the Cretaceous aquifer in northwestern Iowa and southwestern Minnesota directly overlies and recharges the Cambrian-Ordovician aquifer system, the water in both is a calcium sodium sulfate bicarbonate type (fig. 14); the sulfate is derived from oxidation of pyrite in shales of the Cretaceous Dakota Formation.

The chemical character of ground water in the confined parts of the aquifer system is much more variable. In general, the distribution of sulfate, chloride, and sodium concentrations closely resembles the distribution of dissolved solids. The areal distribution of water types in the aquifer system where it is overlain by the Maquoketa confining unit is related mainly to distance from recharge areas and to depth within the regional flow system. The most pronounced differences are along confined flow paths to the south and southeast from the recharge area of northwestern Iowa. As shown by the map of composite hydrochemical facies for the Mount Simon and St. PeterPrairie du Chien-Jordan aquifers (fig. 15), water type changes from a calcium sodium sulfate bicarbonate type in the recharge area of northwestern Iowa to sodium calcium sulfate bicarbonate and sodium-mixed anion (no dominant anion) types to a sodium chloride brine in the Illinois and Forest City basins (fig. 3).

Similarly, the calcium magnesium bicarbonate-type water from the recharge area of eastern Wisconsin changes to the east toward the Michigan basin. It changes first to a calcium sodium sulfate chloride type and then to a sodium sulfate chloride type, in transition to calcium sulfate and calcium chloride brines in the Michigan basin. From northern Illinois, the calcium magnesium bicarbonate-type water grades into a mixed cation (no dominant cation) bicarbonate chloride type before becoming a sodium chloride brine in the Illinois basin. These changes may result from membrane filtration, which would cause retention of calcium and magnesium ions as sodium and chloride ions are forced upward across shale layers (Graf, 1982).

\section{DISSOLVED SOLIDS}

The dissolved-solids content of ground water in the aquifer system generally increases in the direction of ground-water movement-generally in the direction of dip of the rocks - and with depth and increased thickness of the aquifers, especially where they are confined by the Maquoketa confining unit. The increase in dissolved solids is due mainly to the residence time in a flow path. Thus, a long flow path provides more time for the water 


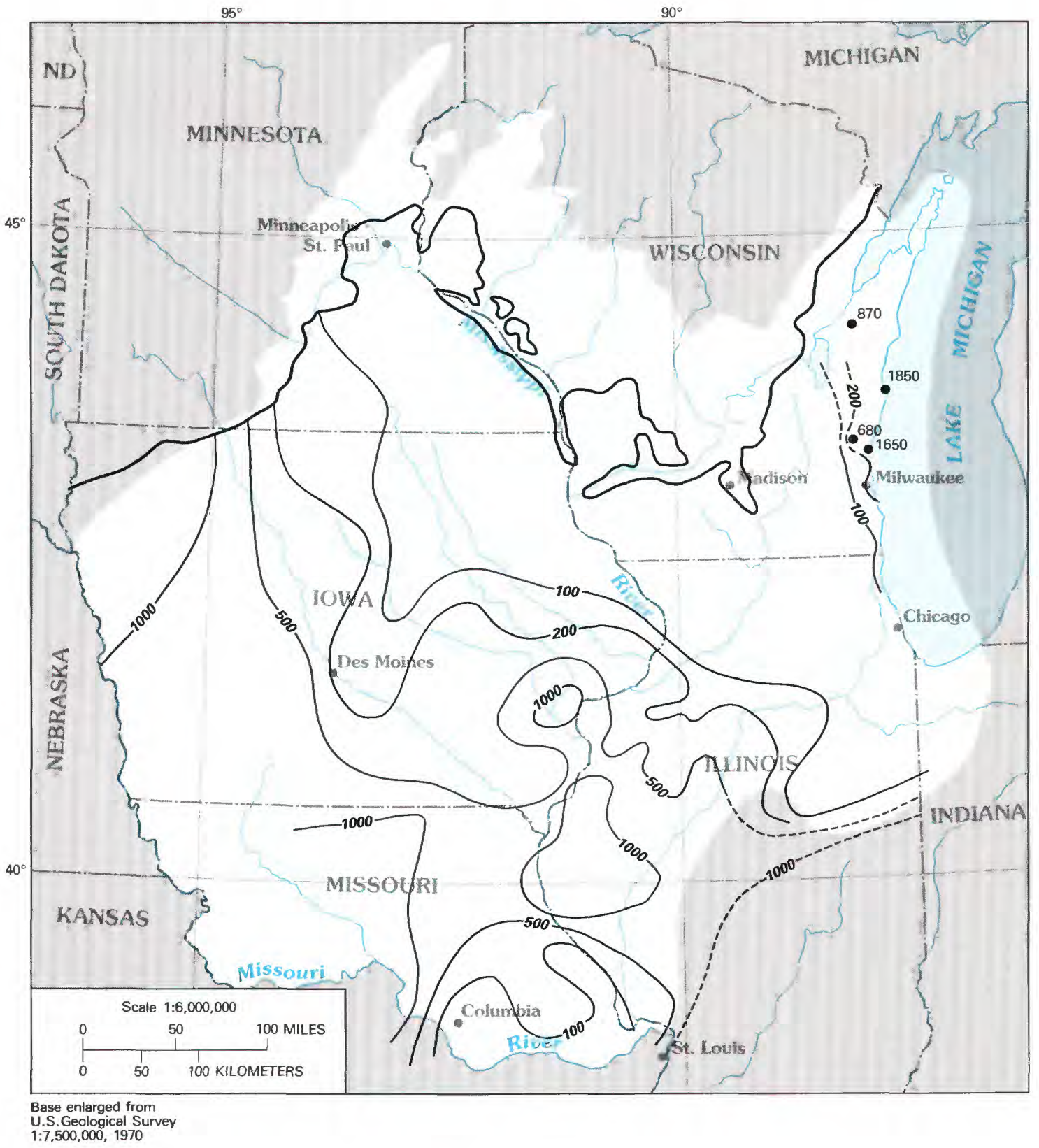

EXPLANATION

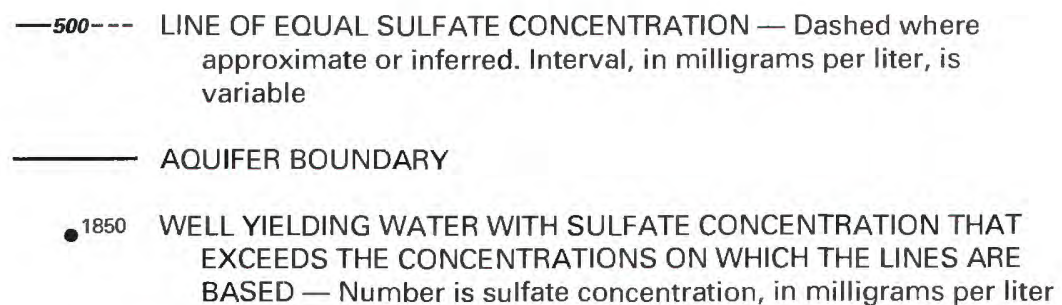

FIGURE 13. -Sulfate distribution in the St. Peter-Prairie du Chien-Jordan aquifer in the northern Midwest. (Modified from Young, in press.) 


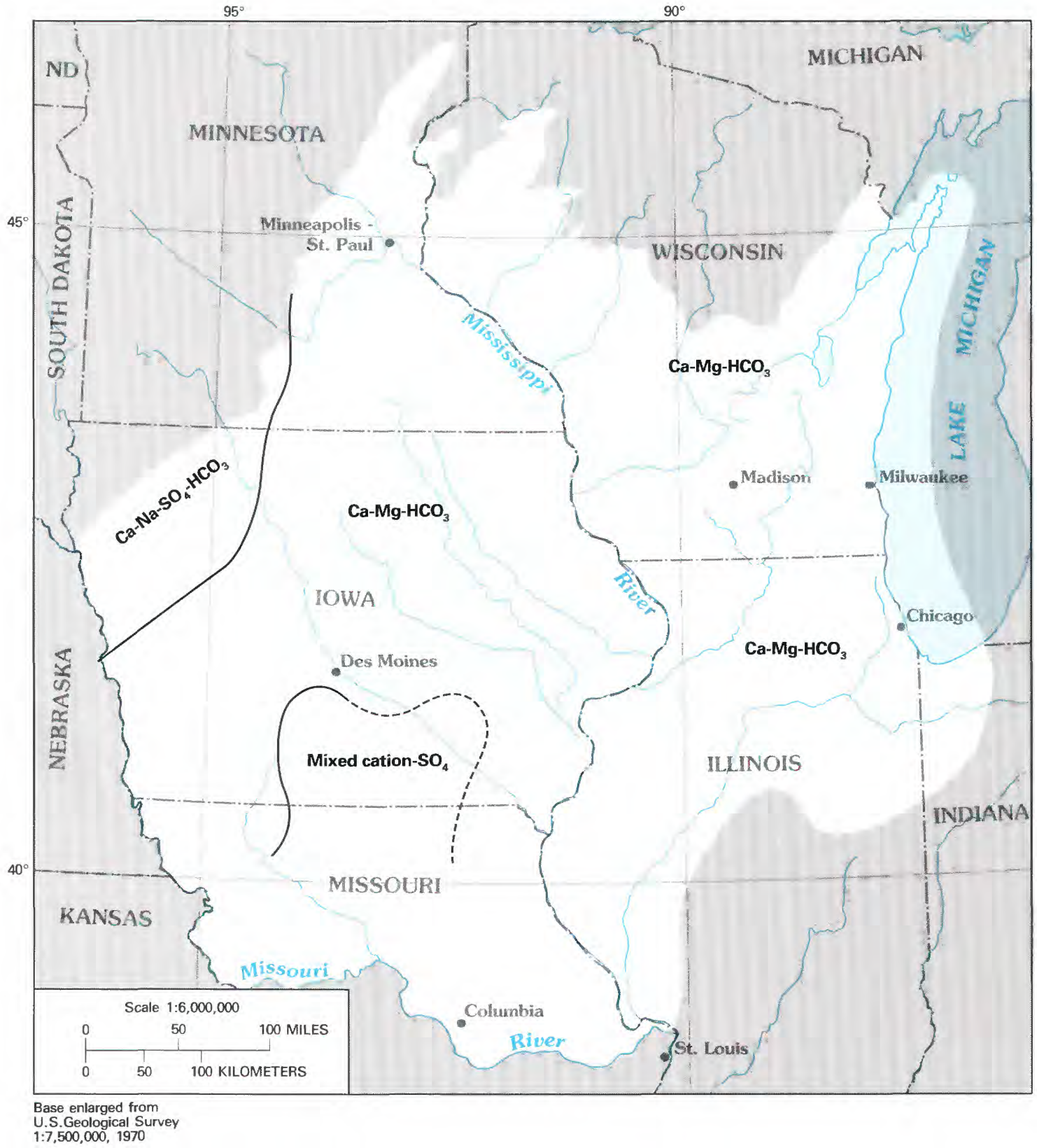

EXPLANATION

\section{FACIES-ZONE BOUNDARY - Dashed where approximate}

Figure 14. - Hydrochemical facies of ground water in the Cretaceous and drift aquifers in the northern Midwest. (From Siegel, 1989.)

to interact with rock minerals. However, some very high concentrations of dissolved solids may be a result of selective ion concentration by shale-membrane filtration or ion exchange. Transition to higher dissolved solids in the confined areas commonly is accompanied by substan- tial increases in sulfate concentration and the presence of calcium sodium sulfate-type water.

The range in concentration of dissolved solids in the Cambrian-Ordovician aquifer system is as extreme as that found in any regional aquifer system. Dissolved 


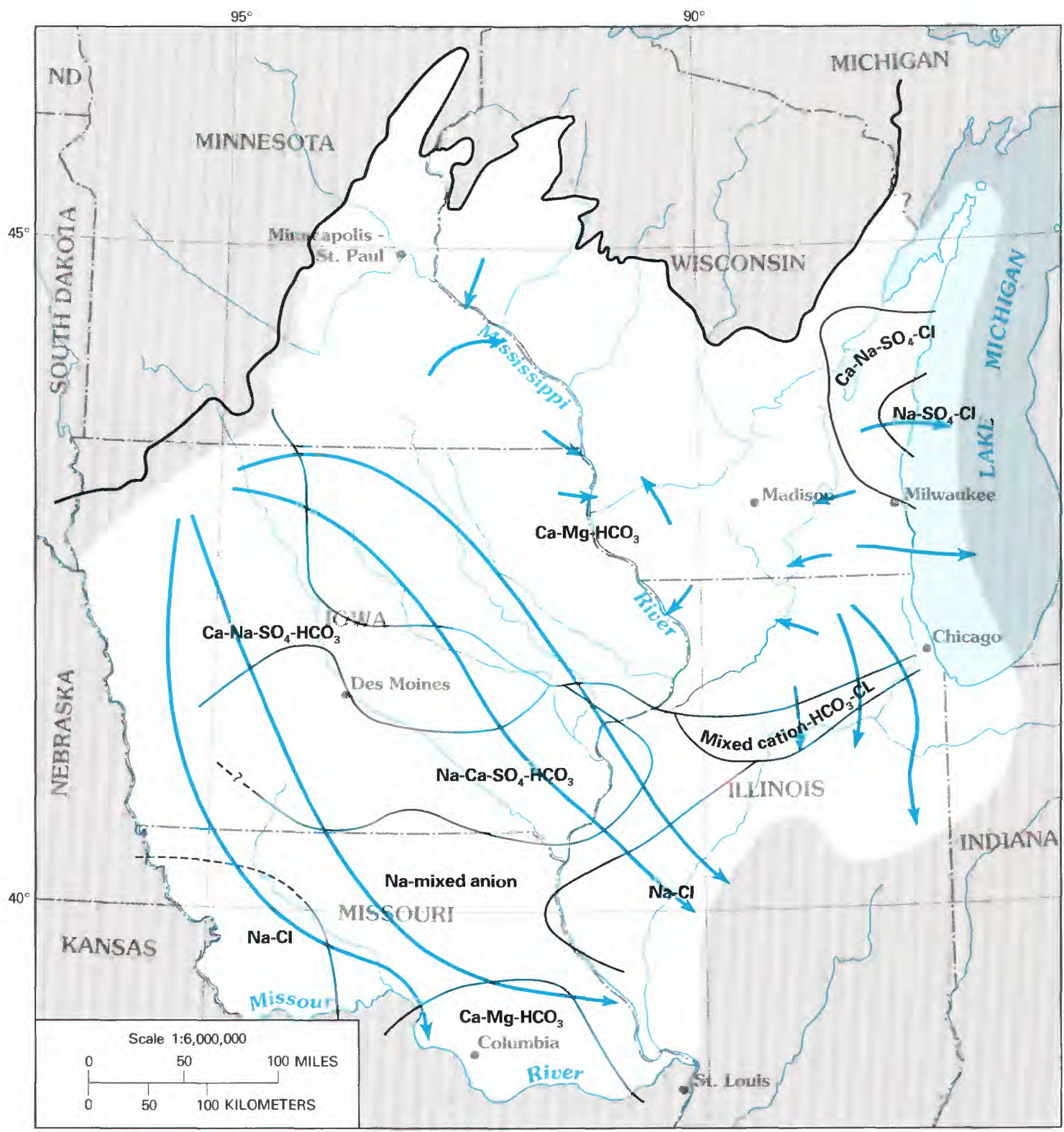

Base enlarged from $1: 7,500,000,1970$
.

\section{EXPLANATION}

\section{$\longrightarrow$ FACIES-ZONE BOUNDARY — Dashed where approximate. Queried where doubtful \\ GENERALIZED DIRECTION OF PREDEVELOPMENT GROUND-WATER FLOW \\ BOUNDARY OF MOUNT SIMON AQUIFER}

FIGURE 15. - Hydrochemical facies of ground water in the Mount Simon and St. Peter-Prairie du Chien-Jordan aquifers in the northern Midwest. (Modified from Siegel, 1989.) 
solids range from less than $400 \mathrm{mg} / \mathrm{L}$ in recharge areas in Wisconsin, southeastern Minnesota, northeastern Iowa, and northern Illinois, where the aquifer system crops out or subcrops beneath glacial drift, to more than 200,000 $\mathrm{mg} / \mathrm{L}$ in the Mount Simon aquifer in the Illinois basin (figs. 16, 17), where the aquifer system is covered with several thousand feet of younger rocks. The $500-\mathrm{mg} / \mathrm{L}$ line of equal dissolved-solids concentration roughly outlines the areas of local, unconfined flow systems in the northern half of the study area. In Illinois and Wisconsin, the line also is approximately parallel to the outcrop pattern of the Maquoketa Shale-the major confining unit between the Cambrian-Ordovician aquifer system and the overlying units. The water in the unconfined aquifer system in those areas is derived from and is identical in type (calcium magnesium bicarbonate) to that in the overlying glacial drift.

The dissolved-solids concentration in the confined Cambrian-Ordovician aquifer system in Iowa generally increases in the direction of the dip of the rocks (perpendicular to the direction of ground-water flow (fig. 12)), toward the Forest City basin and northern Missouri (figs. 16, 17). In addition, in central Iowa, the 500- and $1,000-\mathrm{mg} / \mathrm{L}$ lines define a "plume" of water, fresher than that in the surrounding area, oriented north-south across the Maquoketa Shale outcrop area.

Figures 16 and 17 show several occurrences of dissolved-solids concentration higher than the concentrations generally observed in the vicinity. The high concentrations in the Mount Simon aquifer along the Mississippi River (fig. 16) are in water from deep wells and are indicative of the very slow rate of ground-water movement beneath this regional discharge area. In northeastern Illinois, the very high values are from deep parts of the Mount Simon that are not used for water supply. The reason for the presence of anomalously high dissolvedsolids concentrations in the St. Peter-Prairie du ChienJordan aquifer in eastern Wisconsin (fig. 17) is not clear. One possible explanation is that the rate of upward leakage from the Mount Simon is higher at those locations because the Eau Claire confining unit is absent.

\section{TRACE ELEMENTS AND MINOR CONSTITUENTS}

A reconnaissance survey of the distribution of trace elements in ground water shows that concentrations tend to be higher in confined parts of the aquifer system-a trend generally similar to that for dissolved solids. Concentrations of cadmium, arsenic, and selenium seem to be directly related to the proximity of the Dakota Formation, which overlaps the western edge of the aquifer system in northwestern Iowa and southwestern Minnesota. Iron, manganese, cobalt, cadmium, copper, and lead concentrations are higher near the Dakota
Formation in northwestern Iowa and on the edge of the Forest City basin in southwestern Iowa. Concentrations of beryllium and molybdenum generally are higher near the Forest City basin than elsewhere in the aquifer system. Silica concentrations seem to be directly related to ground-water temperature in south-central Iowa and northern Missouri; however, the solid phases that control the solubility of silica are unknown.

Concentrations of boron (fig. 18), fluoride, lithium, and strontium increase from northeast to southwest in Iowa into northern Missouri, perpendicular to the direction of ground-water flow (see fig. 12). The distribution patterns of lithium, radium-226, and bromide show areas of lower concentrations similar to those of dissolved solids and the stable isotopes of water, which are discussed in the next section. Uranium isotopes in the ground water are at disequilibrium and show unusually high ratios of the activity of uranium-234 to that of uranium-238, generally ranging from about 3 to 30 in Iowa and northern Illinois (Gilkeson and others, 1984; Siegel, 1989). The two largest ratios known are 40.7 in water from the St. Peter Sandstone in southwestern La Salle County, Ill., and 100 in water from a deep packer test in the Mount Simon Sandstone in eastern Jackson County, Iowa.

High barium concentrations in northeastern Illinois and eastern Wisconsin are present in a zone in the confined aquifer system where reducing conditions prevail and markedly lower the sulfate concentration. Barium concentrations increase until the solubility limit of barite $\left(\mathrm{BaSO}_{4}\right)$, a relatively insoluble mineral, is reached. Sulfate concentrations increase progressively eastward from this zone (fig. 13) (discussed in the next section).

High levels of dissolved radium are a special groundwater-quality problem in the Cambrian-Ordovician aquifer system, primarily in the confined parts of the system (Scott and Barker, 1961; Gilkeson and others, 1983; Hahn, 1984). These levels may be related to the unusually high disequilibrium between uranium-234 and uranium-238 in water in sandstones in the aquifer system, possibly because of enrichment of uranium-234 carried in Pleistocene meltwater (discussed in the next section).

\section{EFFECTS OF PLEISTOCENE GLACIATION ON GROUND- WATER QUALITY}

The distribution patterns of dissolved solids and other chemical constituents in the Cambrian-Ordovician aquifer system can be interpreted as residual effects of large-scale continental glaciations during the Pleistocene. Analysis of the isotopic composition of the ground water strongly indicates that the source of much of the ground water in the confined part of the aquifer system was recharge from glacial meltwater. That water is 


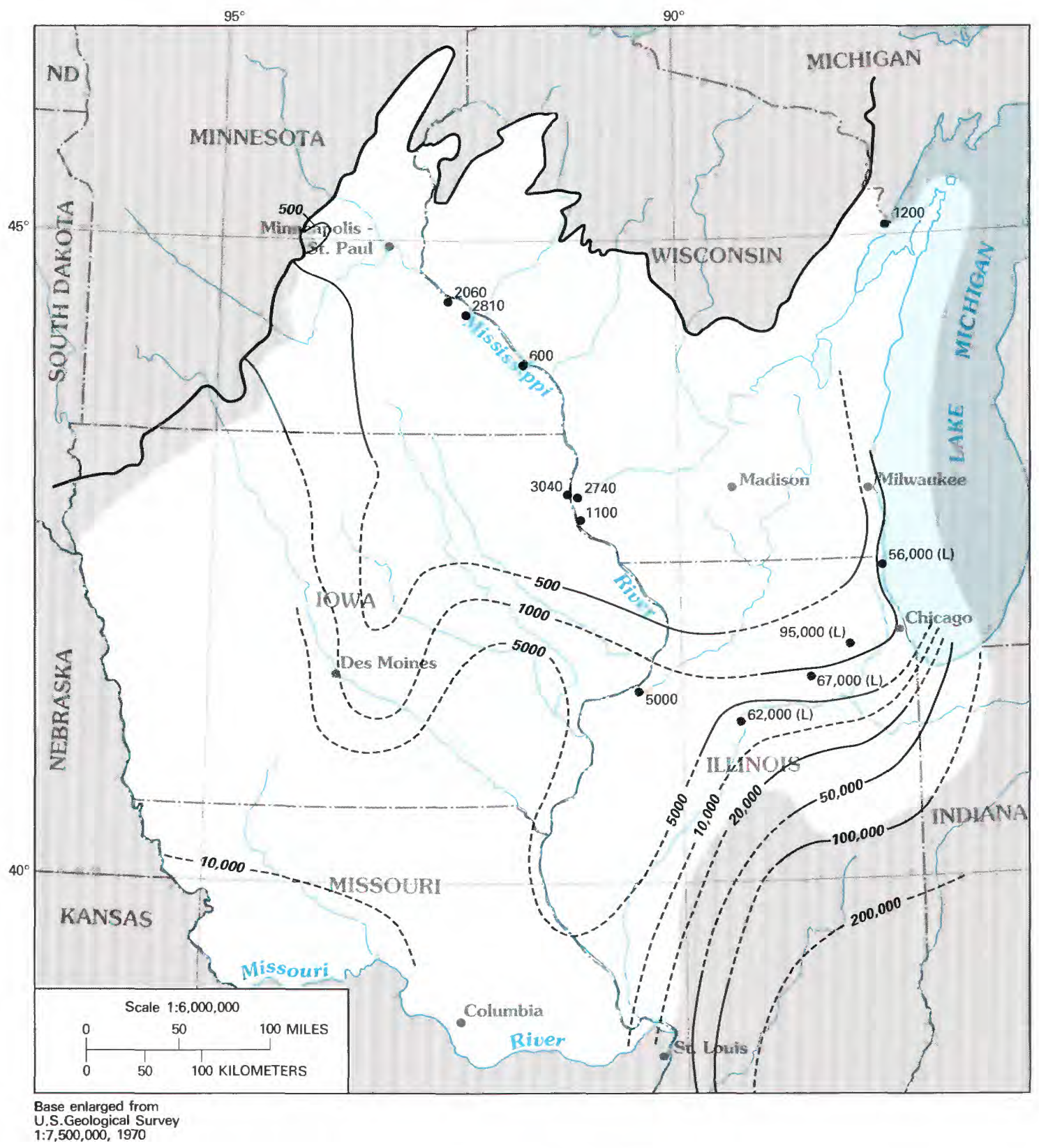

\section{EXPLANATION}

-500--- LINE OF EQUAL DISSOLVED-SOLIDS CONCENTRATION - Dashed where approximate or inferred. Interval, in milligrams per liter, is variable

\section{AQUIFER BOUNDARY}

-3040 WELL YIELDING WATER WITH DISSOLVED-SOLIDS CONCENTRATION THAT EXCEEDS THE CONCENTRATIONS ON WHICH THE LINES ARE BASED - Number is dissolved-solids concentration, in milligrams per liter. $(L)$ indicates water sample from lower part of the aquifer

Figure 16. -Dissolved-solids distribution in the Mount Simon aquifer in the northern Midwest. (From Young, in press.) 


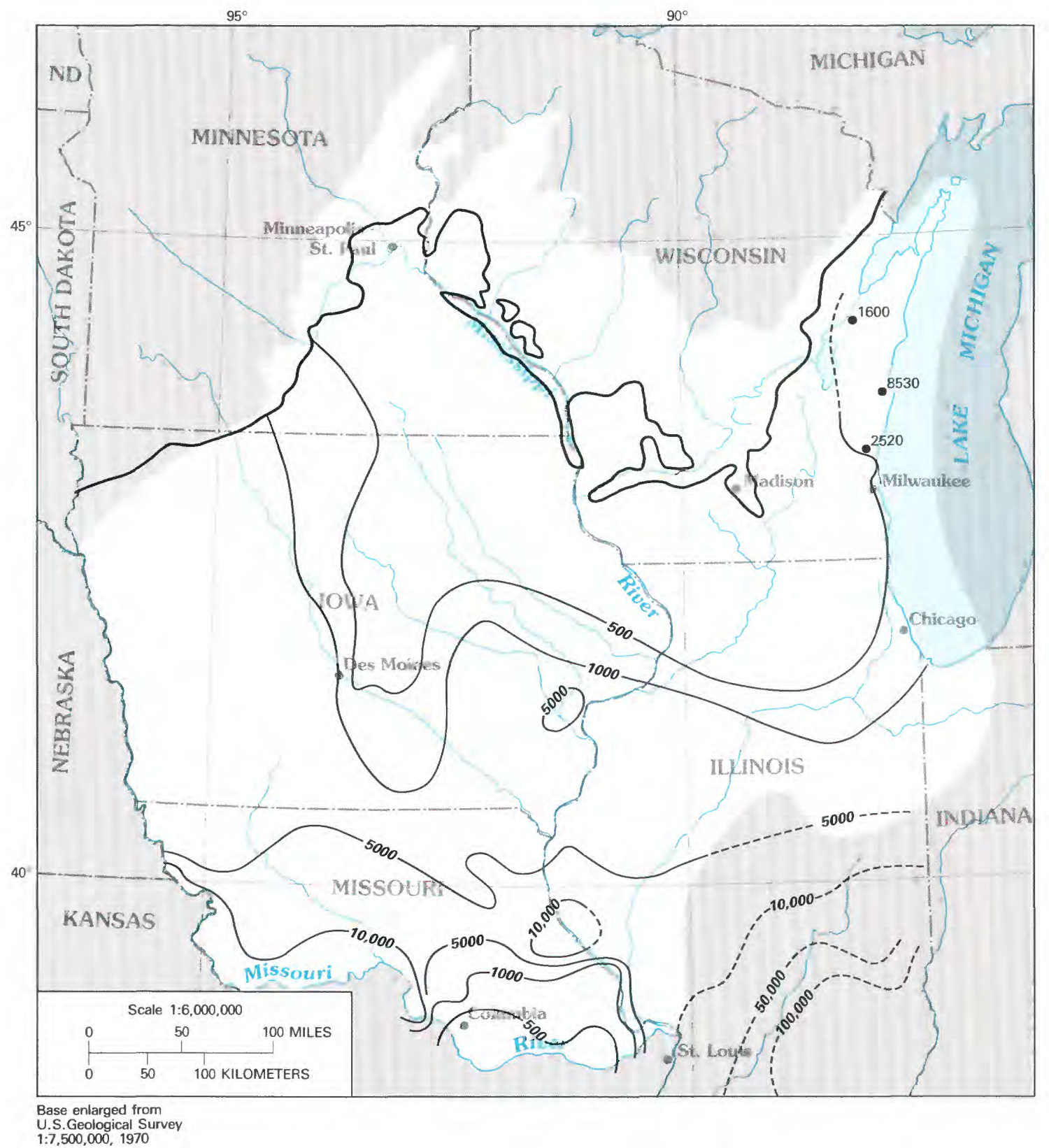

EXPLANATION

-500--- LINE OF EQUAL DISSOLVED-SOLIDS CONCENTRATION — Dashed where approximate or inferred. Interval, in milligrams per liter, is variable

\section{AQUIFER BOUNDARY}

-2520 WELL YIELDING WATER WITH DISSOLVED-SOLIDS CONCENTRATION THAT EXCEEDS THE CONCENTRATIONS ON WHICH THE LINES ARE BASED - Number is dissolved-solids concentration, in milligrams per liter

FIGURE 17.-Dissolved-solids distribution in the St. Peter-Prairie du Chien-Jordan aquifer in the northern Midwest. (Distribution in northeastern Missouri and southern Illinois adapted from Imes (1985) and Meents and others (1952), respectively.) (From Young, in press.) 


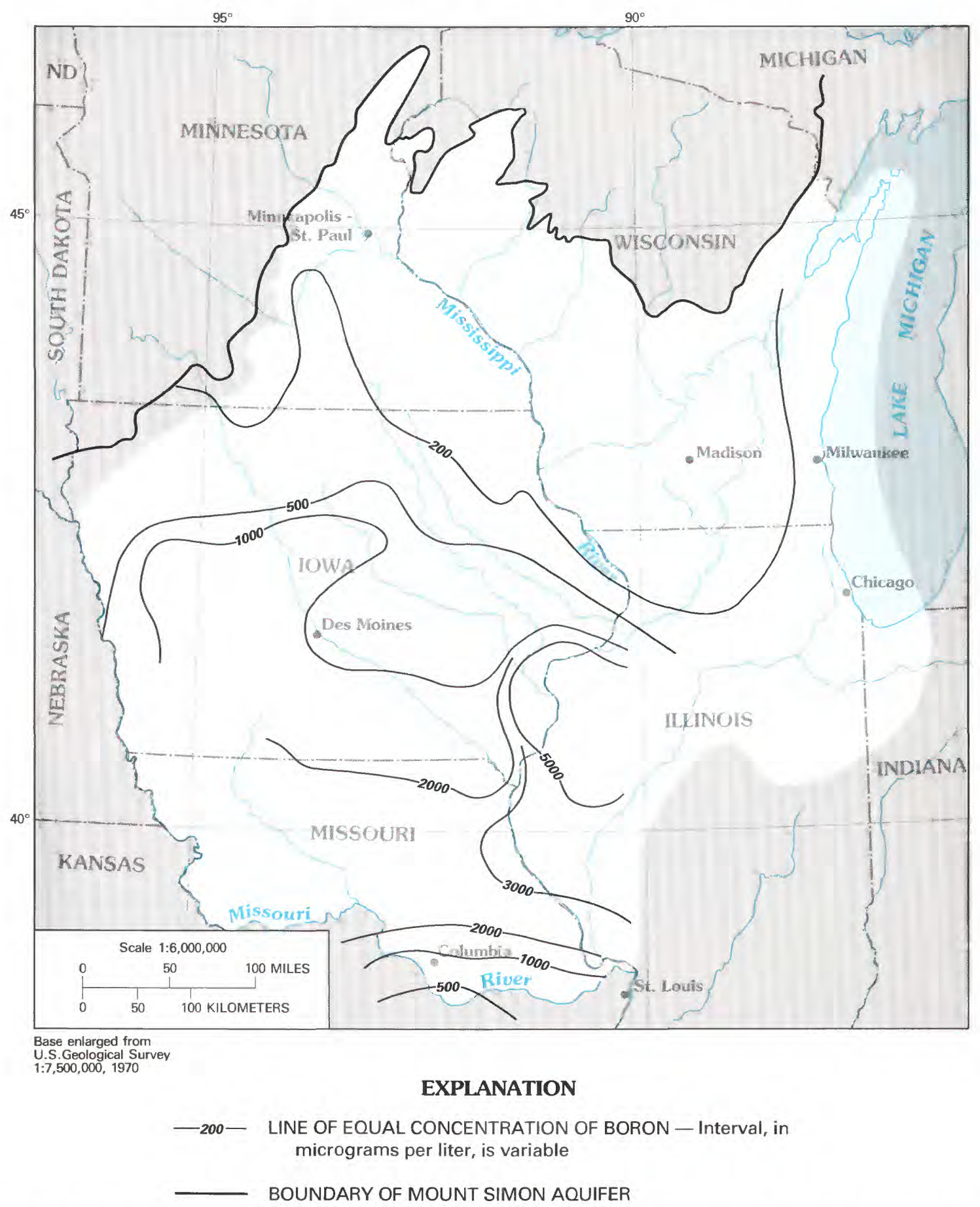

FIGURE 18. -Distribution of boron in the Mount Simon and St. Peter-Prairie du Chien-Jordan aquifers in the northern Midwest. (From Siegel, 1989.)

isotopically depleted in $\delta^{18} \mathrm{O}$ (fig. 19) and $\delta \mathrm{D}$ with respect to modern precipitation - an indication that the source of the water was precipitation in a climate much colder than the present. This is illustrated in the previously mentioned area where ground water in the St. Peter-Prairie du Chien-Jordan aquifer in central Iowa contains low concentrations of dissolved solids. The dilute water contains dissolved-solids concentrations of $500 \mathrm{mg} / \mathrm{L}$ or less, but the adjacent water contains more than $1,000 \mathrm{mg} / \mathrm{L}$ (fig. 17). The depletion of $\delta^{18} \mathrm{O}$ and $\delta \mathrm{D}$ and concentrations 


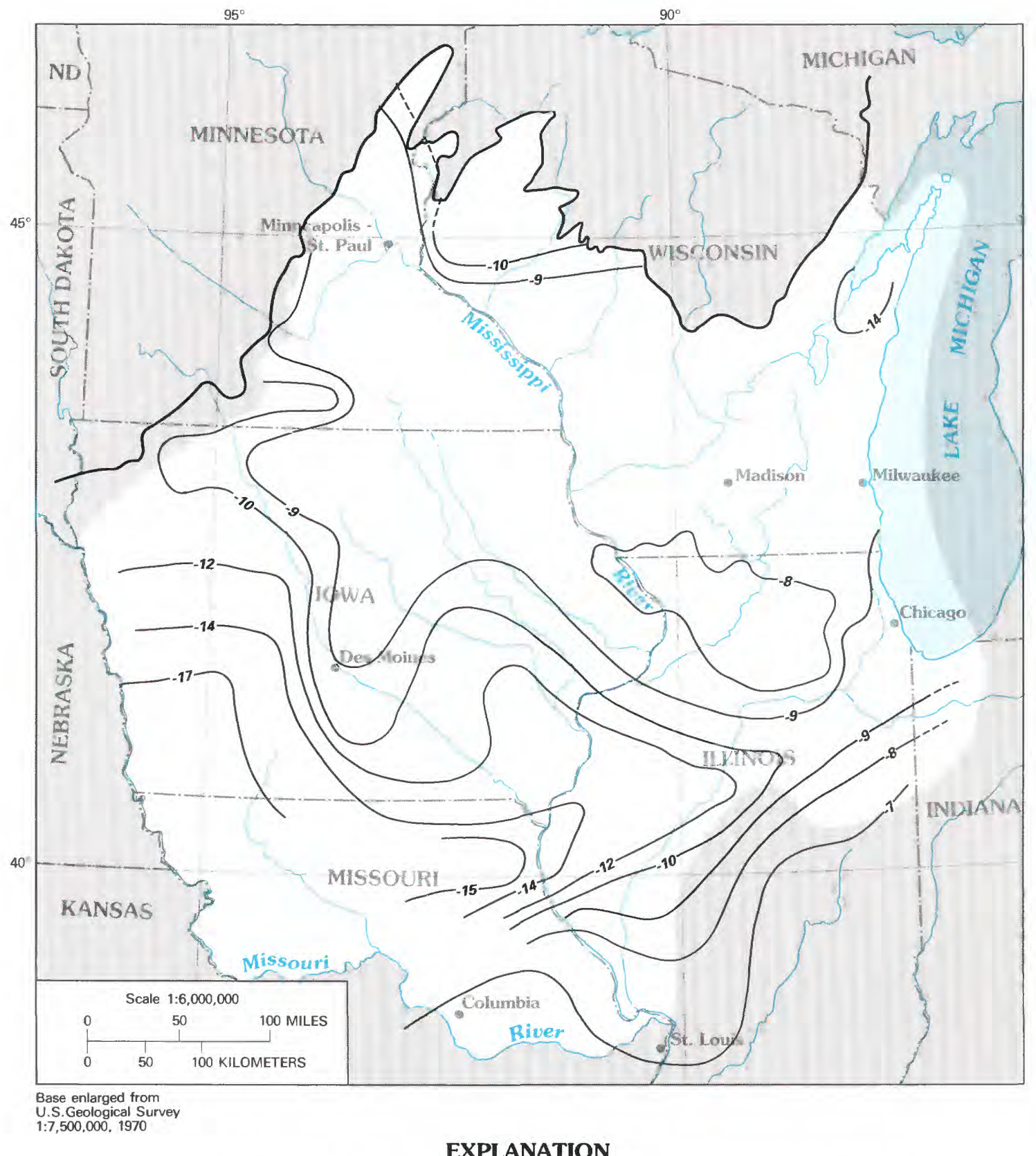

EXPLANATION

-9- LINE OF EQUAL $\delta 180$ RATIO - Dashed where approximate. Interval, in parts per mil, is variable

BOUNDARY OF CAMBRIAN-ORDOVICIAN AQUIFER SYSTEM

Figure 19.-Distribution of $\delta^{18} \mathrm{O}$ ratio in the Cambrian-Ordovician aquifer system in the northern Midwest. (From Siegel, 1989.)

of lithium, radium-226, and bromide also correlate with the pattern of dissolved solids (Siegel, 1989). The northsouth orientation of the area of dilute water suggests a flow system with recharge areas in south-central Minnesota and discharge areas in Missouri, probably because Pleistocene subglacial meltwater directly entered the 
aquifer in its outcrop area in southern Minnesota under very high hydrostatic head from the overlying load of glacial ice.

Gilkeson and others (1983) have postulated that subglacial recharge also accounts for the high disequilibrium between uranium-234 and uranium-238 in the confined aquifer system in northern Illinois. A relatively recent (in geologic terms) source of uranium-234 would be necessary to account for its lack of equilibration with uranium-238. Fine-grained sediment derived from abrasion and crushing of igneous and metamorphic rocks by the glaciers could have been a regional source of uranium-234 influx into the Cambrian-Ordovician aquifer system.

Evidence of isostatic loading by Pleistocene ice sheets may be the isotopic composition of sulfate in saline water in the aquifer system near Lake Michigan in eastern Wisconsin and northeastern Illinois. The first eastward increase in dissolved solids is caused primarily by increases in the concentration of calcium and sulfate. The $\delta^{34} \mathrm{~S}$ values for sulfur in the sulfate are positive (Gilkeson and others, 1984; Siegel and Begor, 1989), indicating that the sulfate is evaporitic in origin. Evaporite minerals are abundant in various younger formations in the Michigan basin but are rare in the Cambrian and Ordovician formations west of Lake Michigan. It is believed that isostatic loading from glacial ice over the Michigan basin created a westward hydraulic gradient, opposite from the eastward gradient that prevailed prior to development and that would have prevailed prior to glaciation. This flow reversal caused saline water in the Michigan basin to discharge westward through the present recharge areas.

Apparent ages of water in the Cambrian-Ordovician aquifer system in southeastern Wisconsin, derived from carbon-14 dating, gradually increase along flow paths eastward from the recharge area, indicating the effects of postglacial recharge and ground-water movement. Dates in and near the present recharge area are about $6,000 \mathrm{yr}$ B.P. and near Lake Michigan are at or near the maximum limit of the method, about $40,000 \mathrm{yr}$ B.P. (D.I. Siegel, Syracuse University, written commun., 1988). A similar increase in age along a flow path southeastward from the recharge area northwest of the Twin Cities artesian basin was reported by Alexander and others (1983).

\section{GROUND-WATER DEVELOPMENT AND ITS EFFECTS}

\section{GROUND-WATER DEVELOPMENT}

An abundant ground-water resource has been an important part of the economic development of the northern Midwest for more than a century. The need for a reliable and abundant water supply was met by drilling deep wells, mainly in the Cambrian-Ordovician aquifer system. Deep wells may have been drilled prior to 1860 , but the earliest documented deep well was drilled in 1864 , to a depth of $711 \mathrm{ft}$ in the Galena-Platteville unit at Chicago (Shufeldt, 1865). The head in this well was $80 \mathrm{ft}$ above land surface, or about $111 \mathrm{ft}$ above Lake Michigan, and the well flowed at a rate of about $400 \mathrm{gal} / \mathrm{min}$ (gallons per minute).

Drilling of deep wells had proliferated throughout the northern Midwest by the 1880's and 1890's, especially where artesian flow was obtainable. Flowing wells were common in several topographically low areas in the Mississippi, Missouri, and Illinois River valleys, near Lake Michigan, and around Lake Winnebago in northeastern Wisconsin. Original heads of more than $100 \mathrm{ft}$ above land surface were recorded at Sheboygan, Milwaukee, and Kenosha, Wis., and at Dubuque, Iowa. The supply from these wells initially was considered inexhaustible, and many wells were allowed to flow unregulated as "fountains" in gardens and parks. Overdraft and interference between closely spaced wells caused a decline in heads in deep wells, and many no longer flowed by the early 1900 's. Inadequate depths of casing and corrosion of iron casing in wells commonly allowed discharge into upper aquifers where the head was lower, adding to the head decline.

Ground-water withdrawals from the CambrianOrdovician aquifer system have increased more or less steadily during the past century of development in direct relation to population growth, especially in population centers, and to economic and industrial development. Total withdrawal from the aquifer system in 1980 was about $680 \mathrm{Mgal} / \mathrm{d}$. The largest concentrations of pumpage in 1979-80 were in the Chicago and Twin Cities metropolitan areas-about $180 \mathrm{Mgal} / \mathrm{d}$ in each area (fig. 20). Elsewhere, a comparison of pumpage by county (fig. 21) shows that withdrawals of $10 \mathrm{Mgal} / \mathrm{d}$ were equaled or exceeded in only a few counties: Dane (43), Waukesha (18), Jefferson (12), and Fond du Lac (11) Counties, Wis., and Winnebago (22) and La Salle (14) Counties, Ill. Withdrawals from individual aquifers in some areas are difficult to estimate because many wells are open to and yield water from more than one aquifer.

In most of the northern part of the study area, the Cambrian-Ordovician aquifer system generally is unconfined and consists of fairly permeable sandstones that are not deeply buried. In this area, moderate to large water supplies are obtained from the lower parts of the aquifer system, except where it thins along its northern eroded edge. The St. Peter-Prairie du Chien-Jordan aquifer is not a primary source of ground water in most of this area, because it is absent owing to erosion or is unsatur- 

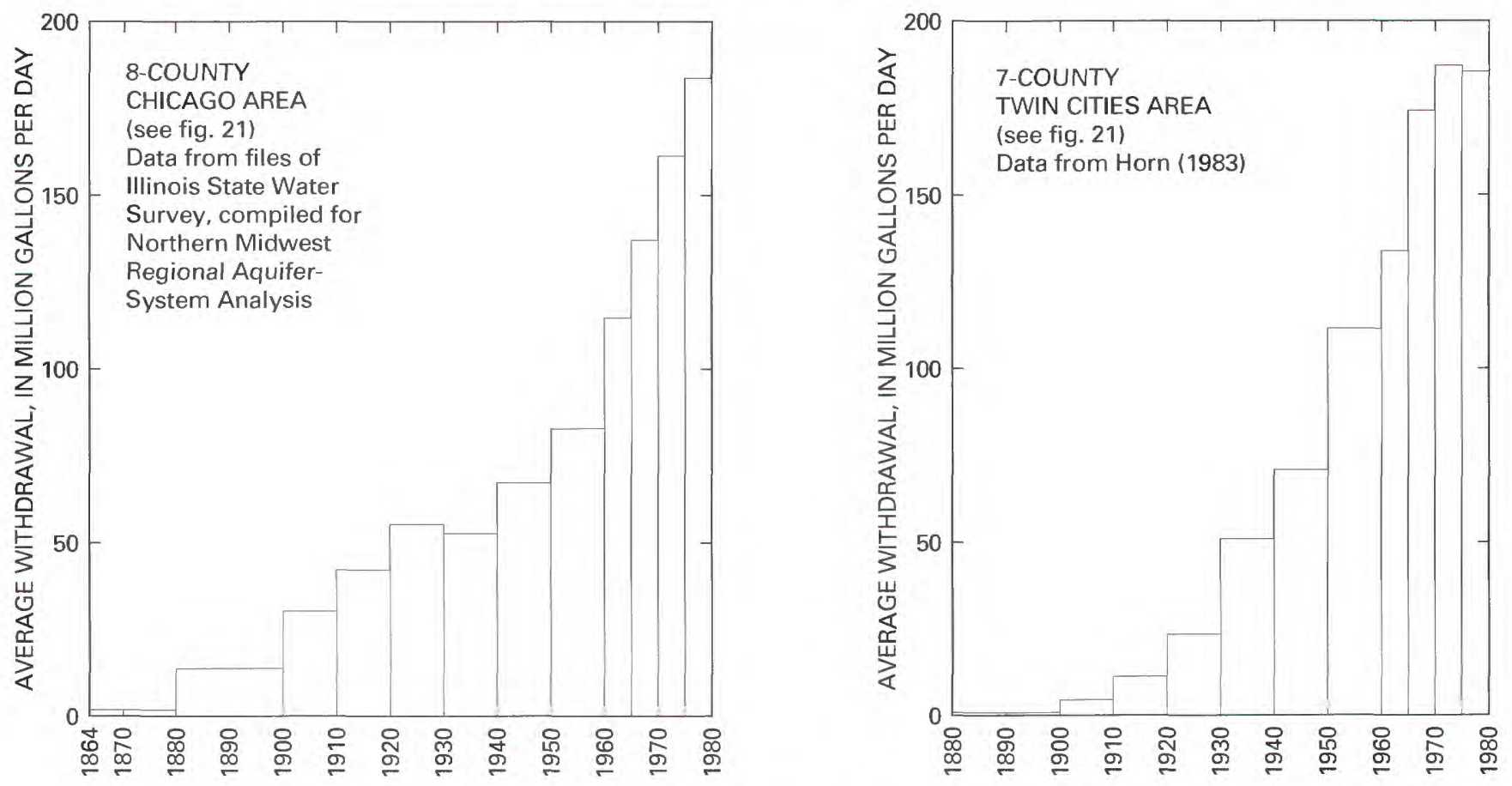

REGIONAL MODEL STRESS PERIOD

FIGURE 20. - Ground-water withdrawals from the Cambrian-Ordovician aquifer system in the Chicago and Twin Cities areas, 1864-1980. (From Young, in press.)

ated owing to its high topographic position. A major exception is the Twin Cities basin in southeastern Minnesota, where the aquifer is highly productive and provides almost 80 percent of the ground water pumped in the metropolitan area. The local Mount Simon-Hinckley aquifer (table 1) contributes about 11 percent of the pumpage from the Cambrian-Ordovician aquifer system in the Twin Cities area.

The confined St. Peter-Prairie du Chien-Jordan aquifer also is a major and very dependable ground-water source in Iowa, where it is termed the "Jordan aquifer" (table 1), and is the only part of the aquifer system commonly used there for large supplies. The aquifer is very productive, and wells generally need not be drilled into underlying aquifers. In addition, the lower aquifers contain increasingly saline water downdip to the south and southwest that is not suitable for most uses.

All the aquifers in the system are productive in most of the confined area of eastern Wisconsin and northeastern Illinois, and most deep wells in these areas are uncased in all rocks that are penetrated below the Maquoketa Shale. The Ironton-Galesville aquifer is the most productive, especially in the Chicago area, where, estimates by Walton and Csallany (1962) show, the aquifer may contribute more than 30 percent of the water to a pumped well open to all the Cambrian and Ordovician rocks. In general, the basal Mount Simon aquifer is not penetrated deeply, for the reasons given earlier. The maximum thickness of Mount Simon penetrated by water wells probably is at Waukesha, Wis. (just west of Milwaukee), where the aquifer's full thickness of about 1,000 to 1,300 $\mathrm{ft}$ is open to several wells. As previously discussed, the Eau Claire Formation north of Milwaukee is not a confining unit, as it is to the south; thus, the entire Elk Mound Group as used in Wisconsin (Ostrom, 1967) produces water to wells.

In the remainder of northern Illinois, especially in the west, local equivalents of the St. Peter-Prairie du ChienJordan aquifer are the main sources of ground water. The Ancell aquifer and the Galena-Platteville unit (table 1) are at or near the surface in those areas and are confined by the Maquoketa Shale in only a few places. Because very large well yields usually are not needed, these shallow bedrock aquifers generally provide an adequate supply of ground water.

Few wells in the Chicago area are open to the Mount Simon aquifer because it contains mostly saline water. Salinity increases with depth in the aquifer and toward the Illinois and Michigan basins, where brines are present. The depth to the Mount Simon and the salinity of its water have made the aquifer more suitable for uses other than water supply. The Mount Simon is used for 


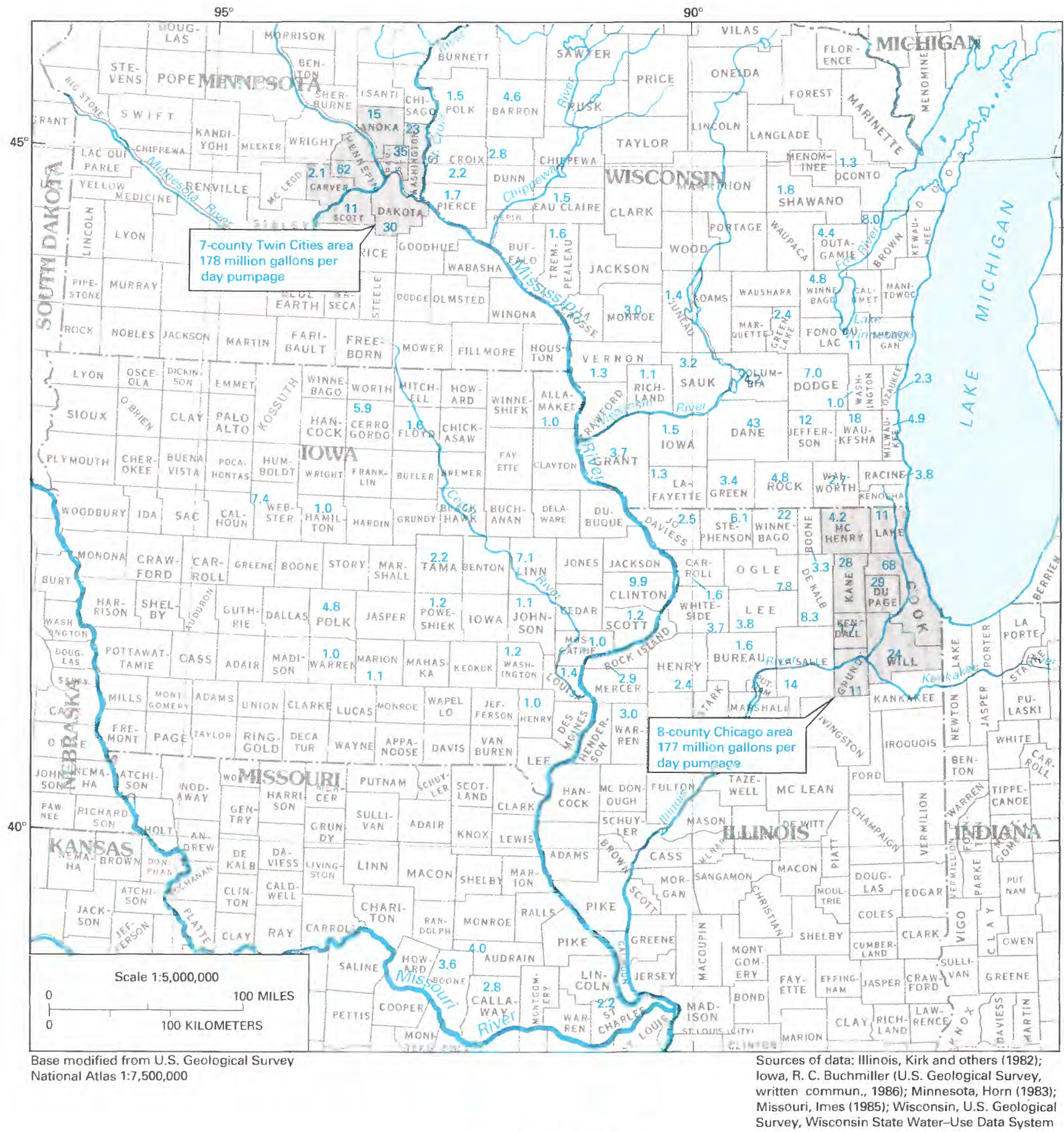

EXPLANATION

2.8 AVERAGE PUMPAGE, IN MILLION GALLONS PER DAY - Number is average total pumpage from the Cambrian-Ordovician aquifer system in those counties with 1 million gallons per day, or more

FIGURE 21. - Major areas of ground-water withdrawal from the Cambrian-Ordovician aquifer system in the northern Midwest, 1979-1980. (From Young, in press.) 
underground storage of natural gas within and on the perimeter of the Illinois basin, and for injection of industrial liquid wastes in a few wells, primarily in northwestern Indiana (Ackermann and others, 1974; Ohio River Valley Water Sanitation Commission, 1976).

Withdrawal from the aquifer system in northern Missouri is limited to a small area in the southeast near the Missouri River (fig. 21), where the water is not highly mineralized (fig. 17). The most productive part of the Cambrian-Ordovician aquifer system in this area is the sequence consisting of the Roubidoux Formation and the Gasconade, Eminence, and Potosi Dolomites (table 1), which are hydraulically equivalent to the regional St. Peter-Prairie du Chien-Jordan aquifer.

\section{EFFECTS ON THE AQUIFER SYSTEM}

Large-scale pumping of ground water from the Cambrian-Ordovician aquifer system has produced large head declines and has altered the direction of groundwater flow in parts of the study area. Changes in water quality also may have occurred.

The 1980 potentiometric surfaces for aquifers of the Cambrian-Ordovician aquifer system (illustrated here as the potentiometric surface for the St. Peter-Prairie du Chien-Jordan aquifer, fig. 22), compared with predevelopment conditions (fig. 12), show little effect from ground-water withdrawal in most of the recharge or unconfined areas; however, major areas of decline are evident in the confined areas. The largest total declines in head and the largest areal extent of the declines are at Chicago, Ill., Milwaukee and Green Bay, Wis., the Quad Cities of Iowa and Illinois, and Mason City, Iowa, where the aquifer system is confined by the Maquoketa confining unit. The head in the composite aquifer system declined more than $900 \mathrm{ft}$ locally (not depicted in fig. 23) in the deepest cones of depression in the Chicago area from 1864 to 1980 and more than $375 \mathrm{ft}$ in the cone of depression at Milwaukee from about 1880 to 1980 (fig. 23). The decline has been $200 \mathrm{ft}$ or more at Mason City and the Quad Cities.

More than $440 \mathrm{ft}$ of head decline occurred at Green Bay between 1886 and 1957, when the city discontinued use of its deep wells and began using water from Lake Michigan. Withdrawal from the Cambrian-Ordovician aquifer system in the Green Bay area decreased from 13.1 to 5.3 $\mathrm{Mgal} / \mathrm{d}$; as a result, the head recovered almost $300 \mathrm{ft}$ by 1960. Continued pumping nearby has decreased head in the area and has shifted the cone of depression a few miles to the south. The bottom of the cone of depression was only $100 \mathrm{ft}$ higher in 1980 than in 1957.

The head decline caused by withdrawals from wellconfined aquifers is larger than that from unconfined or partly confined aquifers. This is illustrated by comparing conditions in the Chicago area with those in the Twin Cities area, and conditions in the Mason City, Iowa, area with those in the Madison, Wis., area. The historical rates and trends of pumping from the CambrianOrdovician aquifers in the Chicago and Twin Cities areas are similar (fig. 20). However, the decline of the composite head below the Maquoketa Shale at Chicago was as much as $900 \mathrm{ft}$ from 1864 to 1980 (Visocky, 1982), but in the Twin Cities area the decline in the Prairie du Chien-Jordan aquifer, which is incised by deep bedrock valleys beneath the Mississippi and Minnesota Rivers, was only about $90 \mathrm{ft}$ from 1890 to 1980 (Schoenberg, 1984). About $200 \mathrm{ft}$ of decline occurred in the underlying Mount Simon-Hinckley aquifer in the Twin Cities area, where the aquifer is confined by the Eau Claire Formation. Similarly, pumpage from the confined Jordan aquifer at Mason City was about $6 \mathrm{Mgal} / \mathrm{d}$ in 1980, and total drawdown was $200 \mathrm{ft}$ (M.R. Burkart and R.C. Buchmiller, USGS, written commun., 1987). However, pumpage from unconfined Cambrian sandstones at Madison was about $40 \mathrm{Mgal} / \mathrm{d}$, and total drawdown was only about $60 \mathrm{ft}$. The cone of depression at Madison induces recharge through deeply incised bedrock valleys and affects only a local area around the city (McLeod, 1975a), whereas the deeper cone at Mason City is part of a large area, which covers two-thirds of Iowa, where head has declined more than $50 \mathrm{ft}$ (Horick and Steinhilber, 1978).

The large head declines in northeastern Illinois, eastern Wisconsin, and eastern Iowa are very apparent because of the increased cost to drill deeper wells and to install and operate pumps at deeper levels. The accompanying change in direction of ground-water flow in and near the pumping centers, however, is less apparent. Where the head in confined parts of the CambrianOrdovician aquifer system has declined to a point below the water table, the original upward flow across the Maquoketa confining unit is now reversed. This has induced downward flow to the aquifer system. This transition occurred roughly in the 1920's in the Chicago and Milwaukee areas. These changes in flow direction may have affected water quality by inducing water having a different composition into the aquifer system within the cones of depression.

The very large head declines in the CambrianOrdovician aquifer system in the Chicago-Milwaukee area (fig. 23) are the most impressive effects of groundwater withdrawal in the northern Midwest. In addition to the $180 \mathrm{Mgal} / \mathrm{d}$ pumped from the aquifer system in an eight-county Chicago area in 1980, about $33 \mathrm{Mgal} / \mathrm{d}$ was pumped in southeastern Wisconsin, mainly in Waukesha and bordering municipalities west of Milwaukee. The development and resulting head decline in the ChicagoMilwaukee area have been described by several investi- 


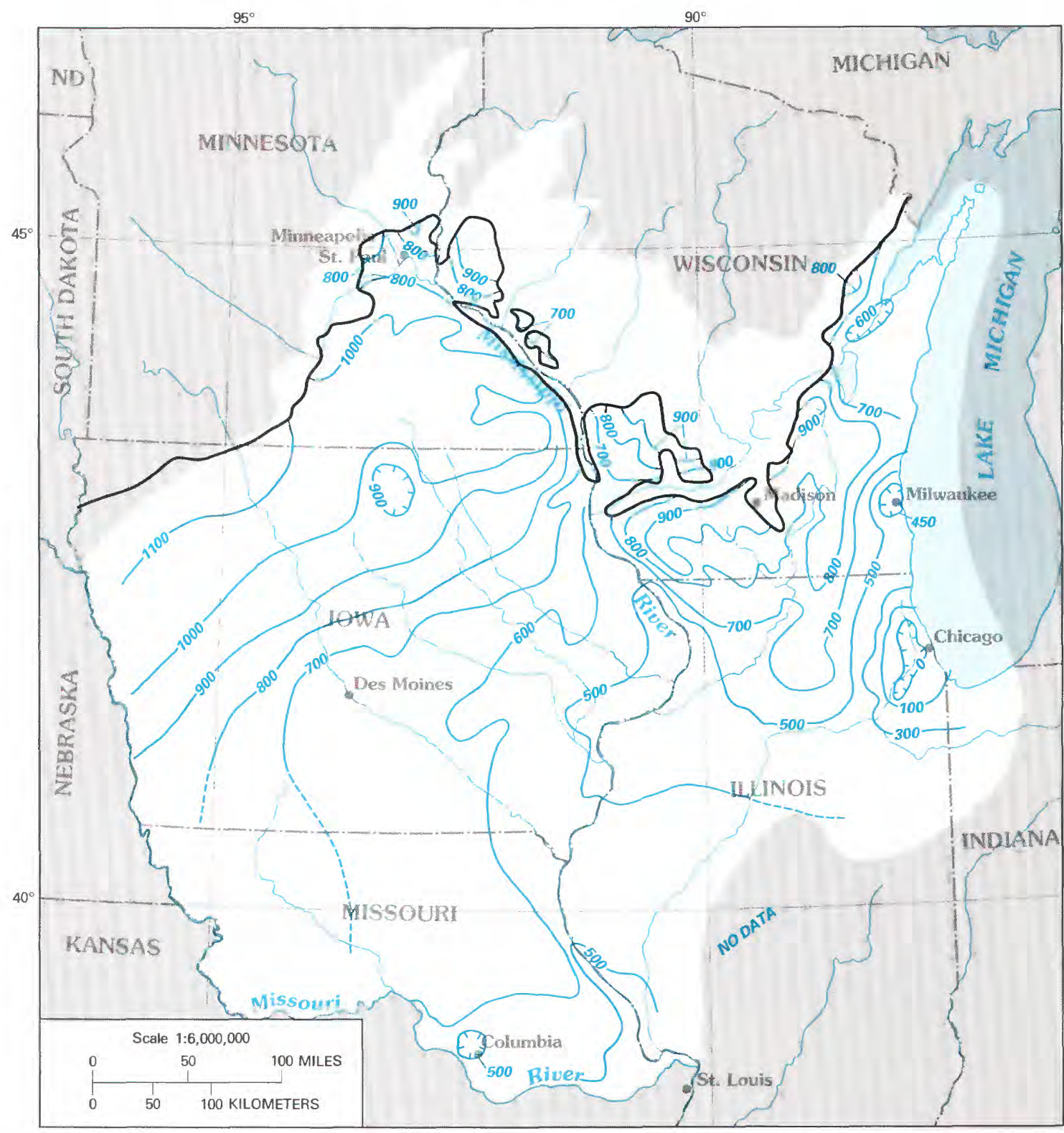

Base enlarged from

U.S.Geological Surver
$1: 7,500,000,1970$

EXPLANATION

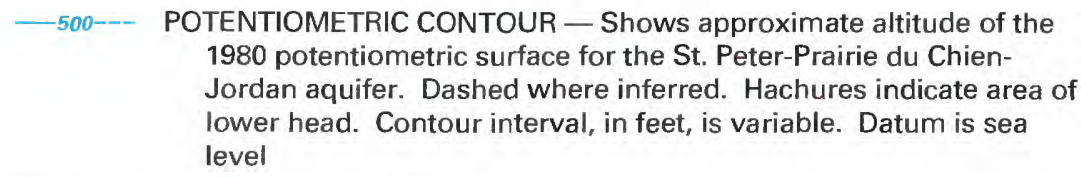

AQUIFER BOUNDARY

FIGURE 22.-Generalized potentiometric surface for the St. Peter-Prairie du Chien-Jordan aquifer in the northern Midwest, 1980. (From Young, in press.) 


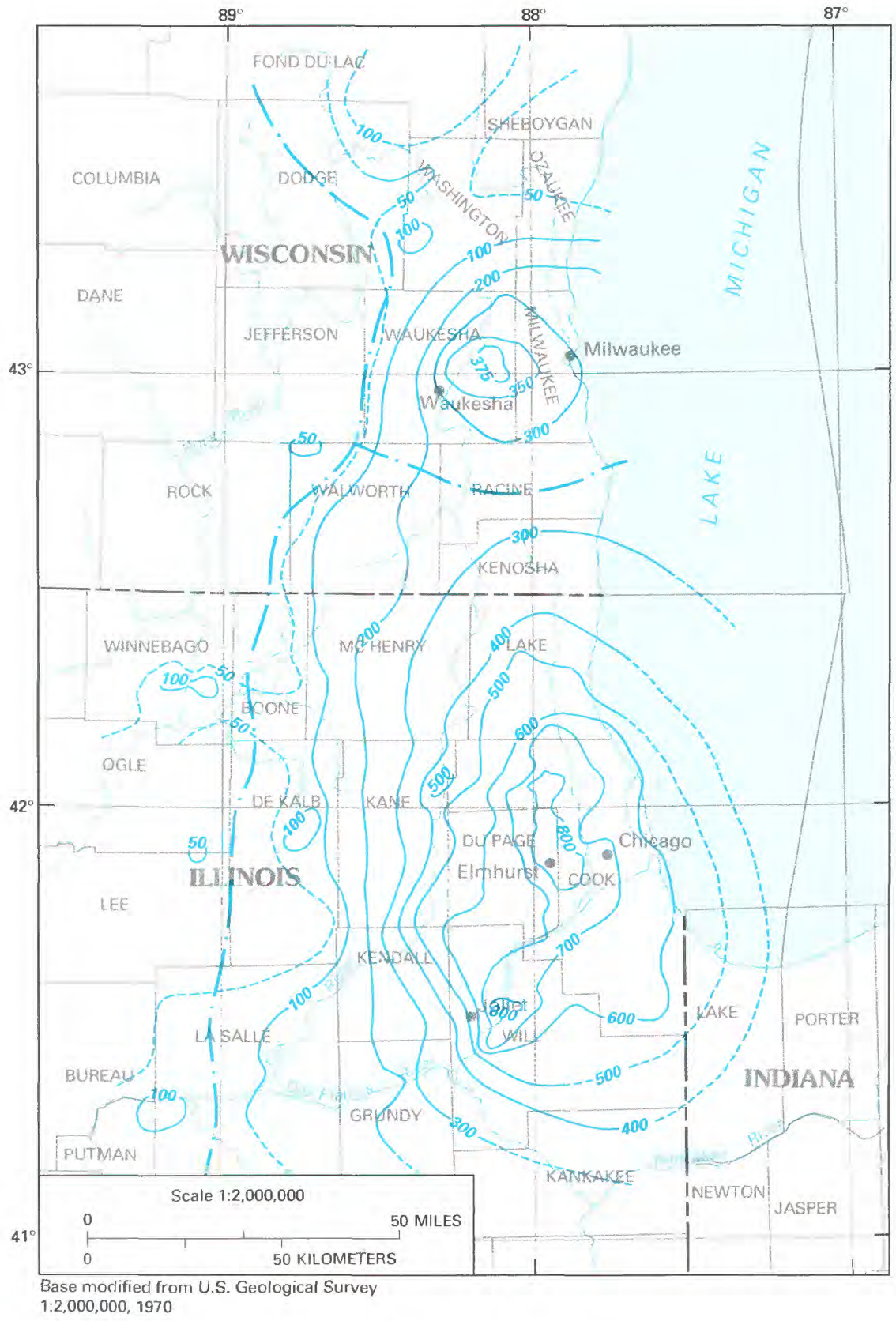

EXPLANATION

-200--- LINE OF EQUAL HEAD DECLINE, 1864-1980 - Dashed where approximate. Interval, in feet, is variable

MAJOR POTENTIOMETRIC DIVIDE

FIGURE 23.-Decline in head in the composite Cambrian-Ordovician aquifer system in the Chicago-Milwaukee area, 1864-1980. (Modified from H.L. Young and A.J. MacKenzie, U.S. Geological Survey, written commun., 1988.) 
gators, but, in general, each study focused on only the part of the aquifer system within each State.

The deepest parts of the regional cone of depression in the Chicago area are in northeastern Du Page County and the adjacent parts of western and northern Cook County, and at Joliet in northwestern Will County. Nonpumping water levels in 1980 in some wells at Joliet and Elmhurst were, respectively, more than 800 and 900 $\mathrm{ft}$ below land surface (more than $200 \mathrm{ft}$ below sea level) (Sasman and others, 1982). The general pattern of the location of these local cones of depression in 1958 (Suter and others, 1959) and in 1980 (Sasman and others, 1982) are quite similar, but the decline in head during this period was greater in the westernmost cones.

The maximum head decline in the Milwaukee area was more than $375 \mathrm{ft}$ by 1980 , and was centered in eastcentral Waukesha County and western Milwaukee. In 1950, a separate cone of depression was centered on the city of Waukesha, $13 \mathrm{mi}$ west of the center of the main cone in central Milwaukee County (Foley and others, 1953). By 1980, however, the Milwaukee cone had expanded westward to include eastern Waukesha County and the Waukesha cone (fig. 23), as pumping centers shifted westward. The total rate of withdrawal in southeastern Wisconsin has remained almost constant since about 1971, even though the population increased, because of water conservation and recycling.

The mutual interference of the pumping centers at Chicago and Milwaukee is shown by the coalescence of the cones of depression, which forms an east-west potentiometric divide in southeastern Wisconsin (fig. 23). This divide moved northward about $6 \mathrm{mi}$ from 1961 to 1980, from the Racine-Kenosha County line (H.L. Young and A.J. MacKenzie, USGS, written commun., 1988) to central Racine County.

The city of Chicago and several nearby communities obtain their water supplies by diverting water from Lake Michigan at a rate that was fixed by a decree of the U.S. Supreme Court (1967). Illinois is allowed a maximum of $1,700 \mathrm{ft}^{3} / \mathrm{s}$ (cubic feet per second) $(1,100 \mathrm{Mgal} / \mathrm{d}$ ) of direct pumpage from the lake for domestic purposes; another $1,500 \mathrm{ft}^{3} / \mathrm{s}(970 \mathrm{Mgal} / \mathrm{d})$ is accounted for by direct diversions to enhance navigation on the Chicago Sanitary and Ship Canal, and by the interception of surface runoff in the Lake Michigan drainage basin to the Chicago and Calumet Rivers, for a total of $3,200 \mathrm{ft}^{3} / \mathrm{s}(2,070 \mathrm{Mgal} / \mathrm{d})$.

Lake Michigan supplies most of the water needs of northeastern Illinois. However, the ground-water resource is an important supplemental supply, and in some areas is the only source of large supply. The previously mentioned $180 \mathrm{Mgal} / \mathrm{d}$ pumped from the Cambrian-Ordovician aquifer system in 1980 was 59 percent of all ground water pumped in the eight-county area. As part of its management of the Lake Michigan water diversion, the Illinois Division of Waters has a policy whereby the use of all ground-water resources must be optimized before an allotment from the diversion is granted; this optimization includes abandonment of deep wells to reduce the rate of head decline in the aquifer system. Completion of major parts of the Tunnel and Reservoir Plan of the Metropolitan Sanitary District of Greater Chicago will decrease the amount of water now diverted from the Lake Michigan basin used for stream dilution to meet water-quality standards. This will allow more diverted water to be allocated to publicsupply and industrial uses (Macaitis and others, 1977).

\section{GROUND-WATER FLOW SIMULATION}

Several computer models have been developed to simulate ground-water flow in the Cambrian-Ordovician aquifer system in all or parts of the northern Midwest (fig. 24). Many of these models have been used to predict head resulting from estimates of future rates of withdrawal of ground water.

\section{REGIONAL MODEL}

A major part of this study was development of a three-dimensional model to simulate regional groundwater flow in the Cambrian-Ordovician aquifer system in the northern Midwest (Mandle and Kontis, in press).

The finite-difference model developed by Trescott (1975) was used, but two major modifications were made to the computer code (Kontis and Mandle, 1988). First, the code was modified to simulate wells that are open to several different aquifers. Without this multiaquifer-well modification, estimates of the contribution of individual aquifer layers to total well discharge must be made prior to simulation. With this modification, only total well discharge is required. In addition, comparison of simulated composite heads with water-level measurements in multiaquifer wells is possible.

The other major modification to the computer code allows simulation of ground-water flow in areas where ground-water density is variable in space but not in time. This modification was made primarily to simulate the effects of the brines on the regional flow system. The model results indicate that ground water of high density is a partial barrier to fresh-ground-water flow, although ground water moves at extremely low flow rates within the areas of high-density ground water.

\section{CONCEPTUAL MODEL}

The regional ground-water flow system was idealized for simulation by combining adjacent geologic units having similar hydraulic properties into aquifers and confin- 


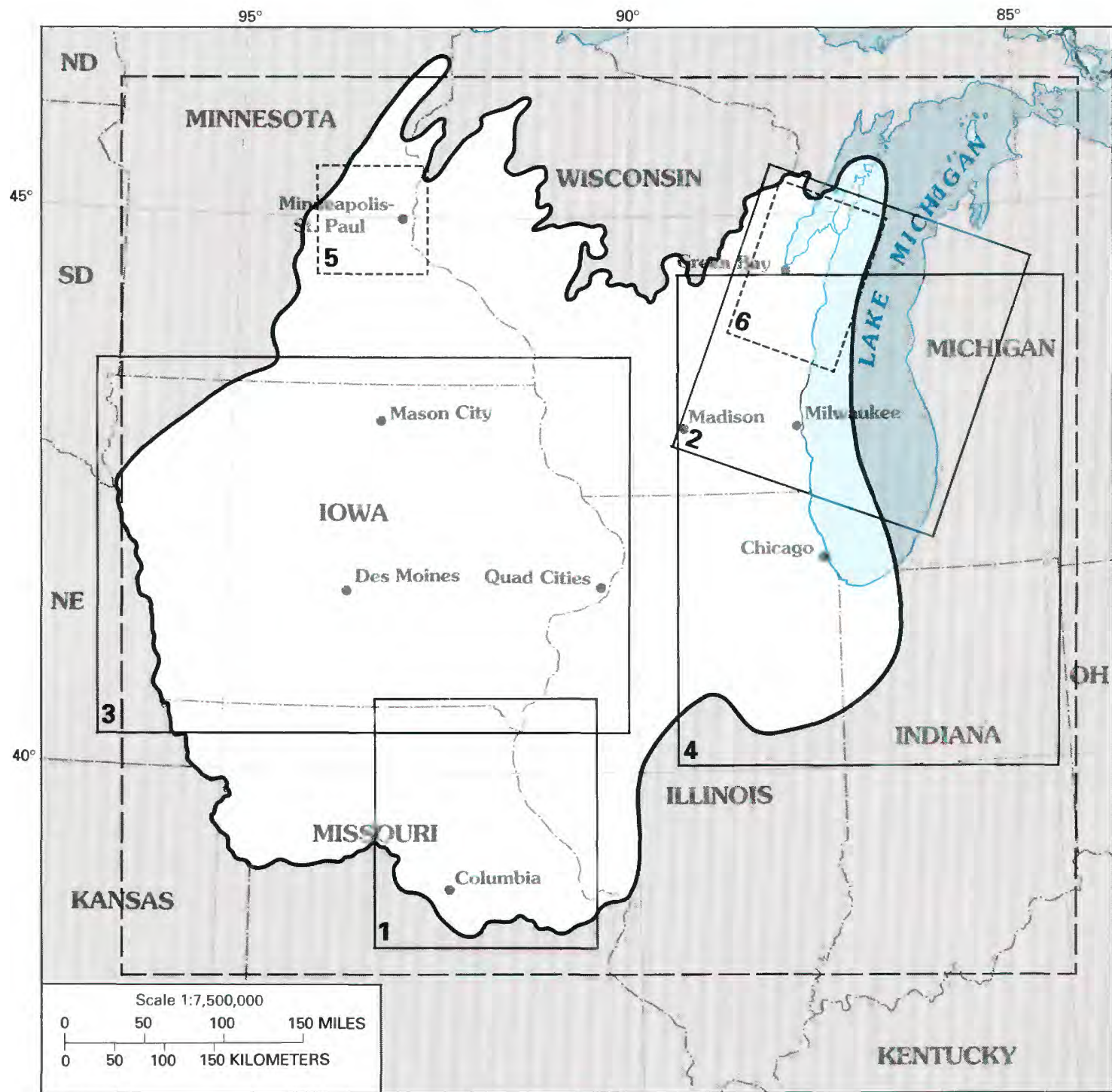

Base from

U.S. Geological Survey

$1: 7,500,000,1970$

EXPLANATION

ᄂ- $\_$REGIONAL GROUND-WATER FLOW MODEL

(Mandle and Kontis, in press)

1 SUBREGIONAL GROUND-WATER FLOW MODEL

1, NE Missouri (Imes, 1985)

2, NE Wisconsin (Emmons, 1987)

3, lowa (Burkart and Buchmiller, in press)

4, Chicago-Milwaukee area (H.L. Young and A.J. MacKenzie, U.S.

Geological Survey, written commun., 1988, and Young and others, 1989)

$\begin{array}{lll}\mathbf{5} & \text { SEPARATE STUDY AREAS }\end{array}$

5, Minneapolis-St. Paul (Guswa and others, 1982)

6, Brown County, Wisconsin (Krohelski, 1986)

\section{STUDY AREA}

FIGURE 24.-Location and areal extent of regional and subregional ground-water flow models of the CambrianOrdovician aquifer system in the northern Midwest. 
ing units, as shown in table 1. The Cambrian and Ordovician rocks that were the focus of this study were subdivided into three pairs of aquifers and overlying confining units. The layering scheme was derived from the northern part of the study area, where the aquifers in the Cambrian-Ordovician aquifer system are primarily sandstones. The equivalent rocks contain more carbonate to the south and generally are less important as aquifers in most of Missouri, central and southern Illinois, and Indiana. To depict the regional characteristics of the flow system, aquifer and confining layers were discretized areally into $16-\times 16$-mi finite-difference blocks. Aquifer properties assigned were either averages of field data or estimates from rock properties and were assumed to be constant within each block. However, the property values can vary from block to block. Consequently, any variability in hydraulic properties or in the characteristics of the flow system on a scale smaller than the 16-mi spacing was not simulated.

Values of hydraulic properties were varied during calibration of the simulations until model results closely correlated with available field data for prepumping conditions prior to 1861 and for pumping conditions from 1861 through 1980. The final set of hydraulic property values used in the simulation is not unique; other combinations of hydraulic property values could have been used during the calibration process, and would have given generally similar results. However, the hydraulic property values obtained during the calibration process in this study are consistent with the available field data, and generally depict the main features of the regional flow system and trends in water-level decline.

The flow equations used in the simulation describe horizontal flow in aquifers in which ground-water density is spatially variable but does not vary with time, and vertical flow between aquifers that occurs as flow through confining units and through multiaquifer wells. These flow equations do not accurately portray real flow conditions where (1) flow in aquifers is not strictly horizontal, such as near partially penetrating wells or streams, (2) flow in confining units is not strictly vertical, such as where confining units contain minor aquifers or locally their horizontal hydraulic conductivity exceeds the vertical hydraulic conductivity, or (3) movement of saline water has occurred and ground-water density varies with time. In addition, the simulation does not account for storage in confining units. This may be significant, especially if the confining units are very thick. Therefore, some degree of error in the simulation is to be expected.

\section{STEADY-STATE SIMULATION}

The model was calibrated for predevelopment steadystate conditions by comparing the simulated heads with the interpreted potentiometric surfaces derived from records of initial heads in the first wells drilled. Hydraulic conductivities of the aquifers and confining units were adjusted to produce a reasonable match between the simulated and derived initial heads.

Simulated steady-state conditions from the regional model show that regional predevelopment ground-water flow in the Cambrian-Ordovician aquifer system was generally to the southeast or east (fig. 25). The aquifer system was recharged in central Wisconsin, southcentral Minnesota, northwestern Iowa, northern Illinois, and central Missouri. Much of the water in the aquifer system discharged locally to rivers and streams where the aquifer system is fully or partly unconfined. Regionally, ground water flowed toward the Michigan basin from eastern Wisconsin and Illinois; toward the Mississippi River from western Wisconsin and Illinois and from eastern Minnesota and Iowa; toward the Missouri River from northern and south-central Missouri; and toward the Illinois basin from northwestern Iowa and northcentral Illinois. The principal regional discharge areas were the Mississippi and Missouri Rivers, the Illinois and Michigan basins, and Lake Michigan.

The simulation indicates that predevelopment recharge from the drift or Cretaceous aquifers into the Silurian-Devonian, St. Peter-Prairie du Chien-Jordan, Ironton-Galesville, and Mount Simon aquifers was about $42,450,47$, and $8 \mathrm{ft}^{3} / \mathrm{s}$, respectively. An additional 24 $\mathrm{ft}^{3} / \mathrm{s}$ entered the Silurian-Devonian aquifer from the overlying Pennsylvanian-Mississippian-Devonian confining unit. Much of this water discharged from local flow systems to streams or to the glacial drift and Cretaceous rocks; discharge totaled $30,370,89$, and $45 \mathrm{ft}^{3} / \mathrm{s}$ from the Silurian-Devonian, St. Peter-Prairie du Chien-Jordan, Ironton-Galesville, and Mount Simon aquifers, respectively. An additional $37 \mathrm{ft}^{3} / \mathrm{s}$ discharged from the SilurianDevonian aquifer to the overlying PennsylvanianMississippian-Devonian confining unit. Thus, simulated total recharge was $571 \mathrm{ft}^{3} / \mathrm{s}$ and was balanced by an equivalent rate of simulated total discharge.

\section{TRANSIENT SIMULATION}

Final calibration of the model was based on a transient simulation of the period 1861 to 1980 , covering the period of development of the aquifer system, which was divided into 12 pumping periods. In addition to hydraulic conductivity, the storage coefficient of the aquifers was 


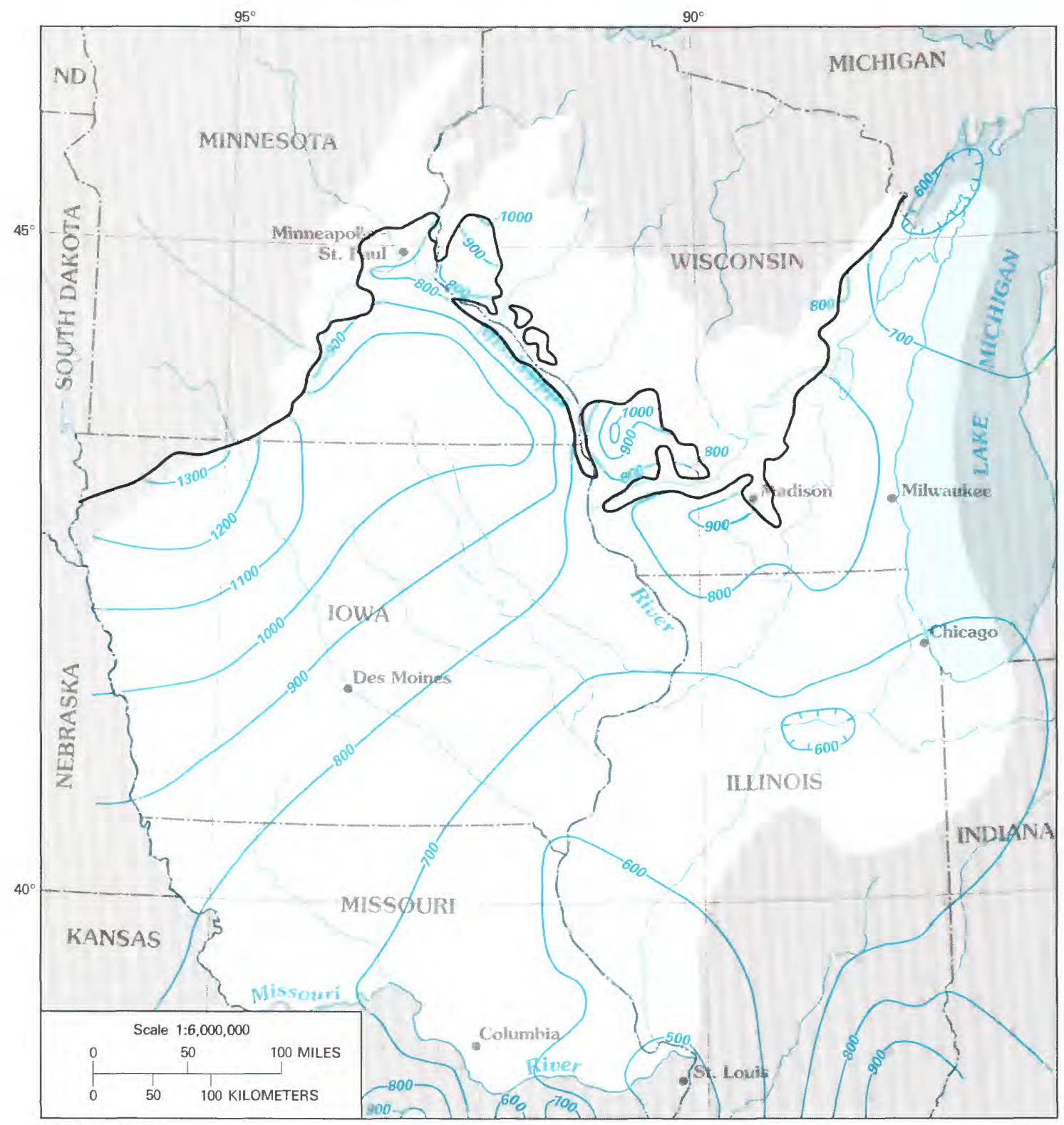

Base enlarged from

U.S.Geological Survey
$1: 7,500,000,1970$

$\longrightarrow 700-$ POTENTIOMETRIC CONTOUR - Shows simulated predevelopment freshwater head in the St. Peter-Prairie du Chien-Jordan aquifer. Hachures indicate area of lower head. Contour interval 100 feet.

Datum is sea level

\section{AQUIFER BOUNDARY}

FIGURE 25. - Simulated predevelopment head in the St. Peter-Prairie du Chien-Jordan aquifer in the northern Midwest. (From Mandle and Kontis, in press.) 
adjusted for transient calibration. The simulated 1980 potentiometric surface for the St. Peter-Prairie du Chien-Jordan aquifer (fig. 26) was compared with the potentiometric surface constructed from measured heads (fig. 22). Simulated cumulative head declines from 1861 to 1980 in the St. Peter-Prairie du Chien-Jordan aquifer (fig. 27) compare favorably with measured composite head declines in the Cambrian-Ordovician aquifer system. The largest differences between simulated and measured head declines occurred along the Mississippi River. A possible explanation for these differences is the discharge from a large number of flowing wells from the late 1800 's and early 1900 's, which was not accounted for in the water-use inventory or in the simulation.

Calibration also included comparison of the simulated heads at selected model nodes with the measured heads within the nodes at various times during the simulation period. The range in measured heads within a given node is large, and the simulated head generally was higher than most measured heads within the node. However, the simulated head declines follow the general trend of head declines shown by the measured heads.

Simulated transient conditions to 1980 show the large areas where water levels in the regional flow system declined (fig. 27) as a result of extensive development of ground water from the Cambrian-Ordovician aquifer system. Flow that would normally discharge to rivers or by leakage to overlying aquifers through confining units is captured by pumped wells within these large cones of depression. In addition to recharge areas identified in the steady-state simulations, induced transient leakage through the confining units due to reversals in direction of vertical gradients caused by pumping also is shown in much of Iowa, eastern Wisconsin, northeastern Illinois, and north-central Missouri.

For the final simulated pumping period, 1976-80, recharge from the glacial drift or Cretaceous rocks was $217,1,069,65$, and $9 \mathrm{ft}^{3} / \mathrm{s}$ to the Silurian-Devonian, St. Peter-Prairie du Chien-Jordan, Ironton-Galesville, and Mount Simon aquifers, respectively. In addition, $38 \mathrm{ft}^{3} / \mathrm{s}$ entered the Silurian-Devonian aquifer from the overlying Pennsylvanian-Mississippian-Devonian confining unit. Thus, total recharge averaged $1,398 \mathrm{ft}^{3} / \mathrm{s}$ for the period 1976-80. The increase in recharge from the steady-state simulation can be attributed to steeper hydraulic gradients near recharge areas or to a reduction in discharge from the different aquifer layers. Simulated discharge to the glacial drift or Cretaceous rocks decreased to $15,266,72$, and $34 \mathrm{ft}^{3} / \mathrm{s}$ from the SilurianDevonian, St. Peter-Prairie du Chien-Jordan, IrontonGalesville, and Mount Simon aquifers, respectively. Discharge from the Silurian-Devonian aquifer to the overlying Pennsylvanian-Mississippian-Devonian confining unit decreased to $24 \mathrm{ft}^{3} / \mathrm{s}$. Pumpage was $1,208 \mathrm{ft}^{3} / \mathrm{s}$; therefore, the total rate of discharge, $1,619 \mathrm{ft}^{3} / \mathrm{s}$, exceeded recharge by $221 \mathrm{ft}^{3} / \mathrm{s}$ (released from aquifer storage), and water levels declined.

Simulated changes in the components of the groundwater budget for the Cambrian-Ordovician aquifer system are summarized in figure 28. Natural predevelopment discharge of $544 \mathrm{ft}^{3} / \mathrm{s}$ ( $351 \mathrm{Mgal} / \mathrm{d}$ ) was balanced by the same amount of recharge. At the end of the simulation period (1980), pumping from the aquifer system totaled $1,058 \mathrm{ft}^{3} / \mathrm{s}(683 \mathrm{Mgal} / \mathrm{d})$, which was obtained from an increase in recharge of $692 \mathrm{ft}^{3} / \mathrm{s}$ (447 Mgal/d), a decrease in natural discharge of $153 \mathrm{ft}^{3} / \mathrm{s}(99 \mathrm{Mgal} / \mathrm{d})$, and release from aquifer storage of $212 \mathrm{ft}^{3} / \mathrm{s}(137 \mathrm{Mgal} / \mathrm{d})$.

Simulated drawdown caused by large-scale regional pumping creates a series of coalescing cones of depression in the confined aquifer system. This is especially evident in the simulated drawdown in the St. PeterPrairie du Chien-Jordan aquifer (fig. 27). Pumping centers in Iowa interfere with one another, as do pumping centers in eastern Wisconsin and northeastern Illinois. Simulations show that continued pumping at current or increased rates would increase the broadening and deepening of the existing regional cones of depression.

\section{SUBREGIONAL MODELS}

Two-dimensional flow models of the Chicago area (Prickett and Lonnquist, 1971), southeastern Wisconsin and the Chicago area (Young, 1976), and the Madison, Wis., area (McLeod, 1975a, 1975b) were made prior to this regional study. Two USGS cooperative program studies benefited from joint data-collection efforts with this study: they were three-dimensional flow model studies of the Minneapolis-St. Paul area (Guswa and others, 1982) and the Brown County, Wis., area (Krohelski, 1986). Four subregional areas were modeled as part of this regional study. Two-dimensional flow models were prepared of the Cambrian-Ordovician aquifer system in northern Missouri (Imes, 1985) and of the Jordan aquifer in Iowa (Burkart and Buchmiller, in press). Three-dimensional flow models of the aquifer system in northeastern Wisconsin (Emmons, 1987) and in the Chicago-Milwaukee area (discussed in the following section) also were prepared.

The two-dimensional model of the Chicago area by Prickett and Lonnquist (1971) was later used by Schicht and others (1976) and Visocky (1982). Mark Collins and Steven Burch (Illinois State Water Survey, written commun., 1990) have recently (1989) revised that model.

The three-dimensional model of the ChicagoMilwaukee area made during this regional study is an important subregional study and, therefore, is briefly discussed here. 


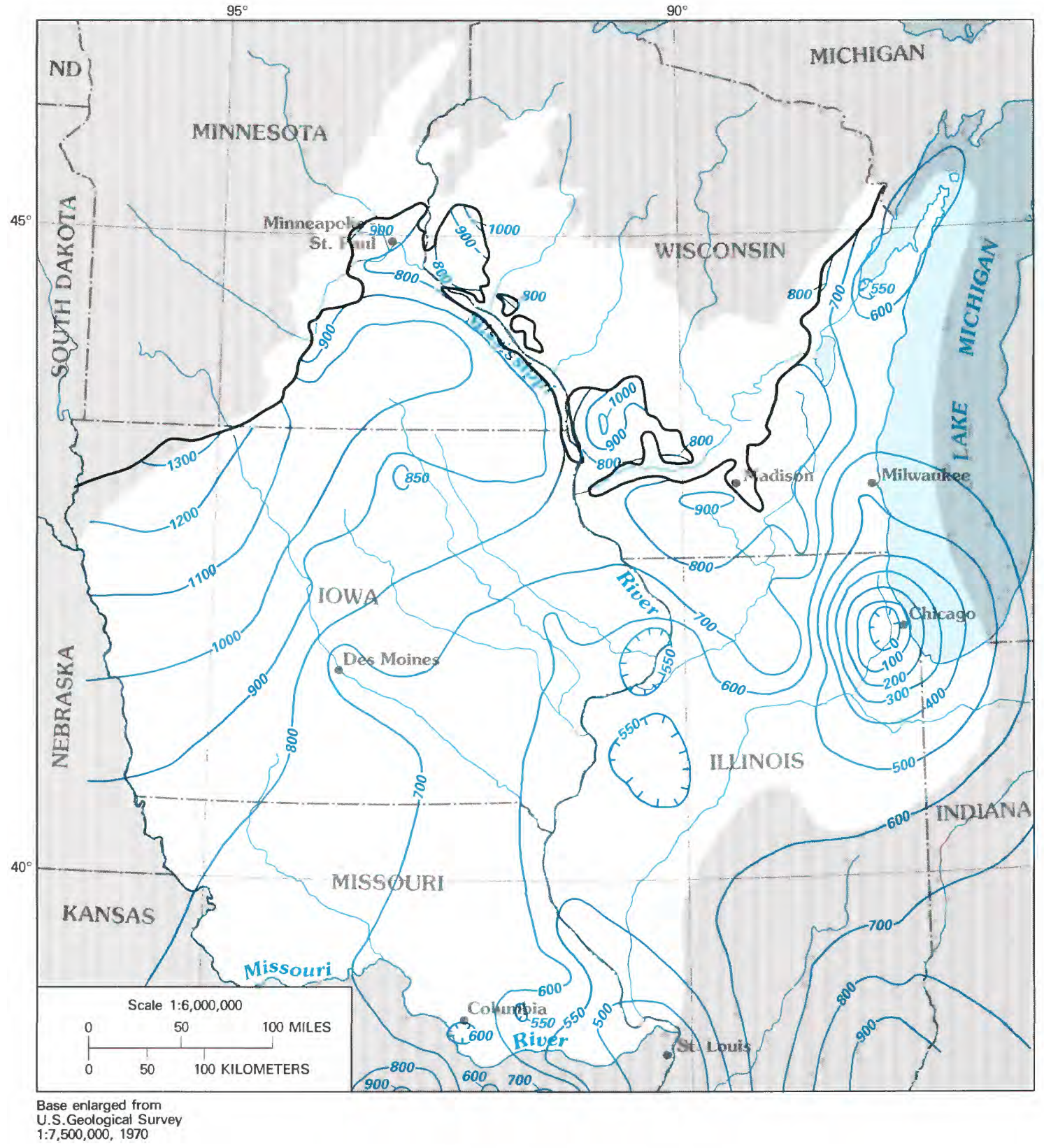

— 700 - POTENTIOMETRIC CONTOUR - Shows simulated 1980 freshwater head in the St. Peter-Prairie du Chien-Jordan aquifer. Hachures indicate area of lower head. Contour interval, in feet, is variable. Datum is sea level

\section{AOUIFER BOUNDARY}

FIgure 26. -Simulated 1980 head in the St. Peter-Prairie du Chien-Jordan aquifer in the northern Midwest. (From Mandle and Kontis, in press.) 


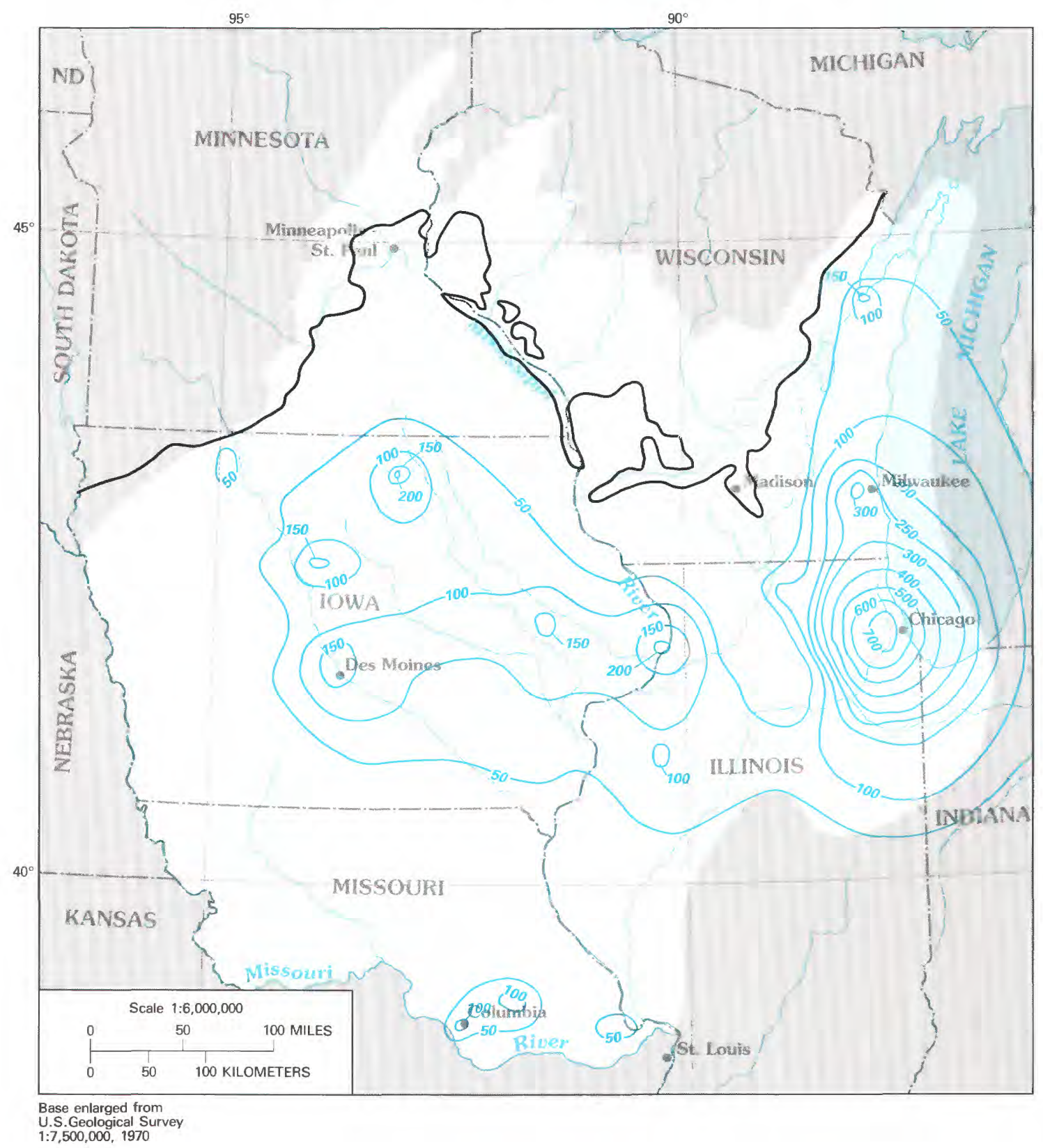

EXPLANATION

$-700-$ LINE OF EQUAL SIMULATED FRESHWATER HEAD DECLINE IN THE
ST. PETER-PRAIRIE DU CHIEN-JORDAN AQUIFER, 1861-1980Interval, in feet, is variable

\section{AQUIFER BOUNDARY}

FIGURE 27.-Simulated decline in head in the St. Peter-Prairie du Chien-Jordan aquifer in the northern Midwest, 1861-1980. (From Mandle and Kontis, in press.) 


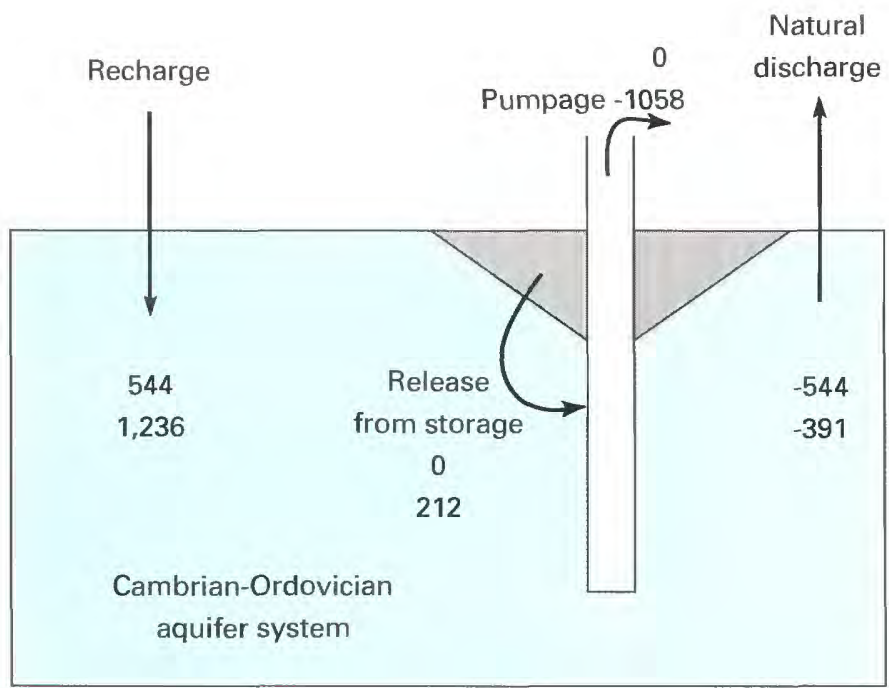

\section{EXPLANATION}

$\begin{array}{cl}0 & \text { SIMULATED COMPONENTS OF THE GROUND- } \\ -1058 & \text { WATER BUDGET FOR THE CAMBRIAN- } \\ & \text { ORDOVICIAN AQUIFER SYSTEM, DERIVED } \\ & \text { FROM THE REGIONAL FLOW MODEL - } \\ & \text { Positive number indicates a source of water } \\ & \text { to the aquifer system, a negative number } \\ & \text { indicates a discharge from the aquifer system. } \\ & \text { Upper number is predevelopment, steady-rate } \\ & \text { and lower number is } 1980 \text { transient rate, in } \\ & \text { cubic feet per second }\end{array}$

Figure 28. - Simulated water budget for the Cambrian-Ordovician aquifer system in the northern Midwest.

\section{CHICAGO-MILWALKEE AREA MODEL}

The last phase of the Northern Midwest RASA study consisted primarily of the preparation of a threedimensional model of the Chicago-Milwaukee area (H.L. Young and A.J. MacKenzie, USGS, written commun., 1988; Young and others, 1989). This is the first simulation of three-dimensional flow in the aquifer system for this area. The previously mentioned models of the area simulate only two-dimensional flow and treat the Cambrian-Ordovician aquifer system as one uniform aquifer layer. The three-dimensional model uses a similar approach to model layers (fig. 29), multiaquifer wells, transient stress periods, and constant-head water table as used in the regional model (Mandle and Kontis, in press), but it does not account for variable water density. The eastern boundaries of both the regional and this subregional model extend to the center of the Michigan basin (fig. 24).

A major difference between the regional and ChicagoMilwaukee area models is the treatment of the
Maquoketa confining unit and the Galena-Platteville unit. In both models, the dolomitic Galena-Platteville unit is included as part of the Maquoketa confining unit where it is overlain by the Maquoketa Shale (fig. 11). In the regional model, the Galena-Platteville unit is considered to be an aquifer where it is not overlain by the Maquoketa. In the Chicago-Milwaukee area model, the Galena-Platteville unit is considered to be an aquifer where it is not overlain by the Maquoketa and also is less than $250 \mathrm{ft}$ thick, in which case it is added to the St. Peter-Prairie du Chien-Jordan aquifer. This thickness was chosen arbitrarily to define areas where the confining characteristics of the Galena-Platteville unit probably are not diminished by secondary permeability as a result of surficial weathering and fracturing. The resulting western boundary of the modeled Maquoketa confining unit of the Chicago-Milwaukee area model is shown in figure 23.

The model was developed in two stages: a steady-state simulation to determine predevelopment conditions, and a transient simulation of the full period of development, 1864-1985. The transient period was divided into 13 stress periods of various lengths to best approximate the changes in rates of withdrawal and to accommodate key calibration dates. These calibration dates were 1961, 1980 , and 1985, when the most complete measured head data were available for both the Illinois and Wisconsin parts of the study area. As described for the regional model, most of the head data available are for multiaquifer wells; therefore, calibration was based on the composite heads in the aquifer system.

\section{Steady-State Simulation}

Results of the steady-state simulation provide an understanding of the major components of the natural ground-flow system, especially in relation to flow patterns and interaquifer head differences. The general pattern of predevelopment flow in the CambrianOrdovician aquifer system can be interpreted from the simulated potentiometric surface and from areal distribution of vertical flow direction through the top of the St. Peter-Prairie du Chien-Jordan aquifer (fig. 30). Flow in the northern two-thirds of the area generally was to the east or west from the potentiometric divide that extends from eastern Dodge County, Wis., to western De Kalb County, Ill. The bedrock valleys beneath the Illinois and Fox Rivers in central La Salle County, Ill., are cut deeply into the St. Peter-Prairie du Chien-Jordan aquifer. Lack of confinement by the Maquoketa confining unit and the topographic low of the river valleys create a regional discharge area. The heads in the discharge areas are much lower in the St. Peter-Prairie du Chien-Jordan aquifer than in the aquifers below; thus, this discharge 


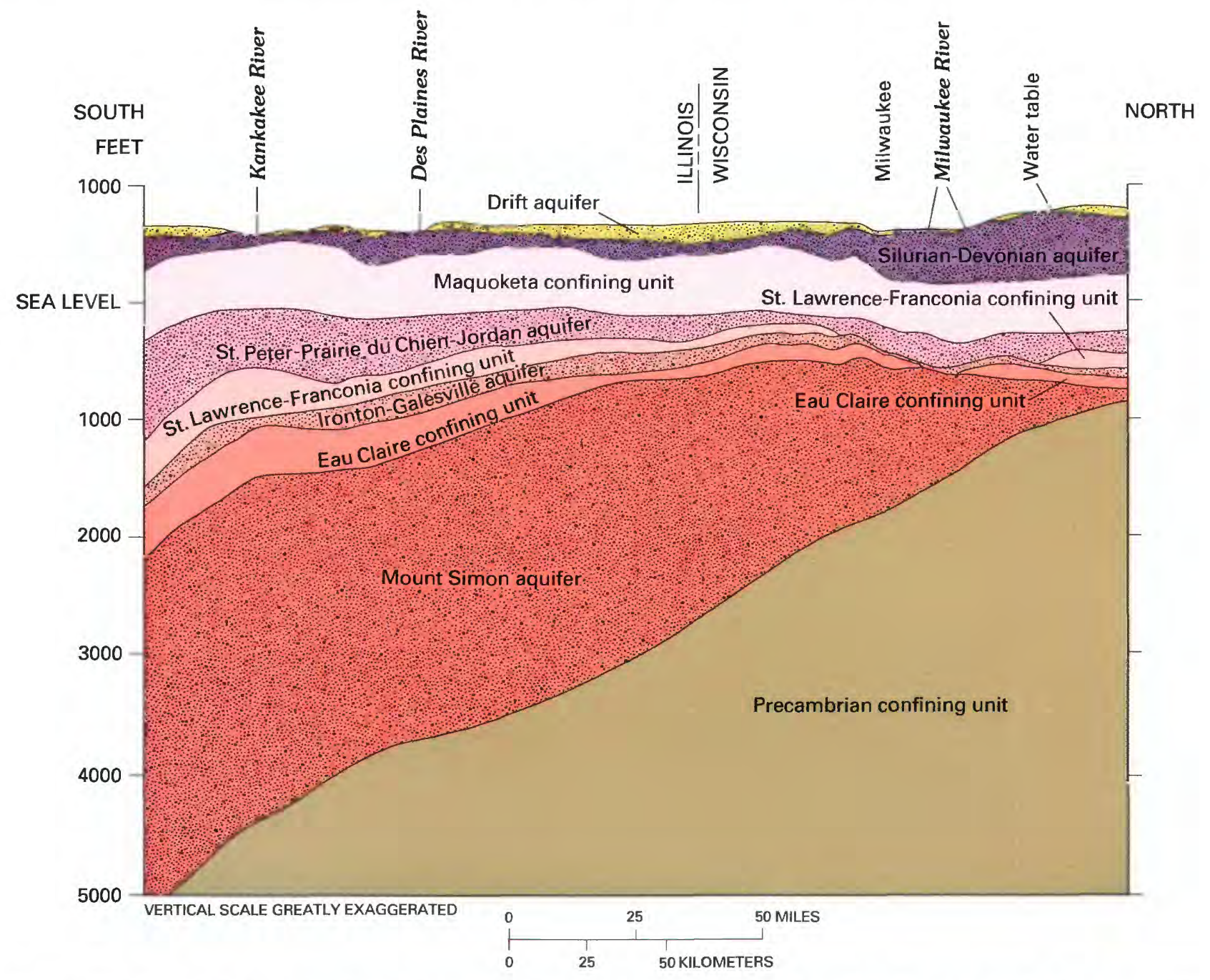

FIGURE 29. - Geohydrologic section along Chicago-Milwaukee area model column 21. (From H.L. Young and A.J. MacKenzie, U.S. Geological Survey, written commun., 1988.)

area controlled the flow pattern in the southern part of the area. These simulated patterns compare favorably with the estimated predevelopment conditions for this area shown in figure 12.

The patterns of vertical flow direction shown in figure 30 are similar to the patterns for the aquifers below, with two main differences. The area of downward flow east of the potentiometric divide extended somewhat farther eastward for the Mount Simon aquifer, closer to Lake Michigan, because of slightly higher head in the aquifers above. Vertical flow through the top of the Mount Simon aquifer was upward in the entire eastern half and southern third of the study area, reflecting the good confinement of the Mount Simon by the Eau Claire.

Simulated vertical head differences were relatively small between each of the Cambrian-Ordovician aquifers below the Maquoketa confining unit, but were much larger between the water table and these aquifers. Beneath the Maquoketa, head differences within the aquifer system generally were less than $5 \mathrm{ft}$, but to the west, where the confining unit is partly or completely absent, head differences were larger, generally ranging from 10 to $30 \mathrm{ft}$. The largest differences were in La Salle and Grundy Counties, Ill., where heads in the St. Peter-Prairie du Chien-Jordan aquifer are depressed around a natural discharge area along the Illinois River valley.

The most striking feature was the high head in the Cambrian-Ordovician aquifers - as much as 100 to $150 \mathrm{ft}$ higher than the water table along the western shore of Lake Michigan. Heads of 750 to $800 \mathrm{ft}$ above sea level in this area (fig. 30 ) were derived from the high water table 


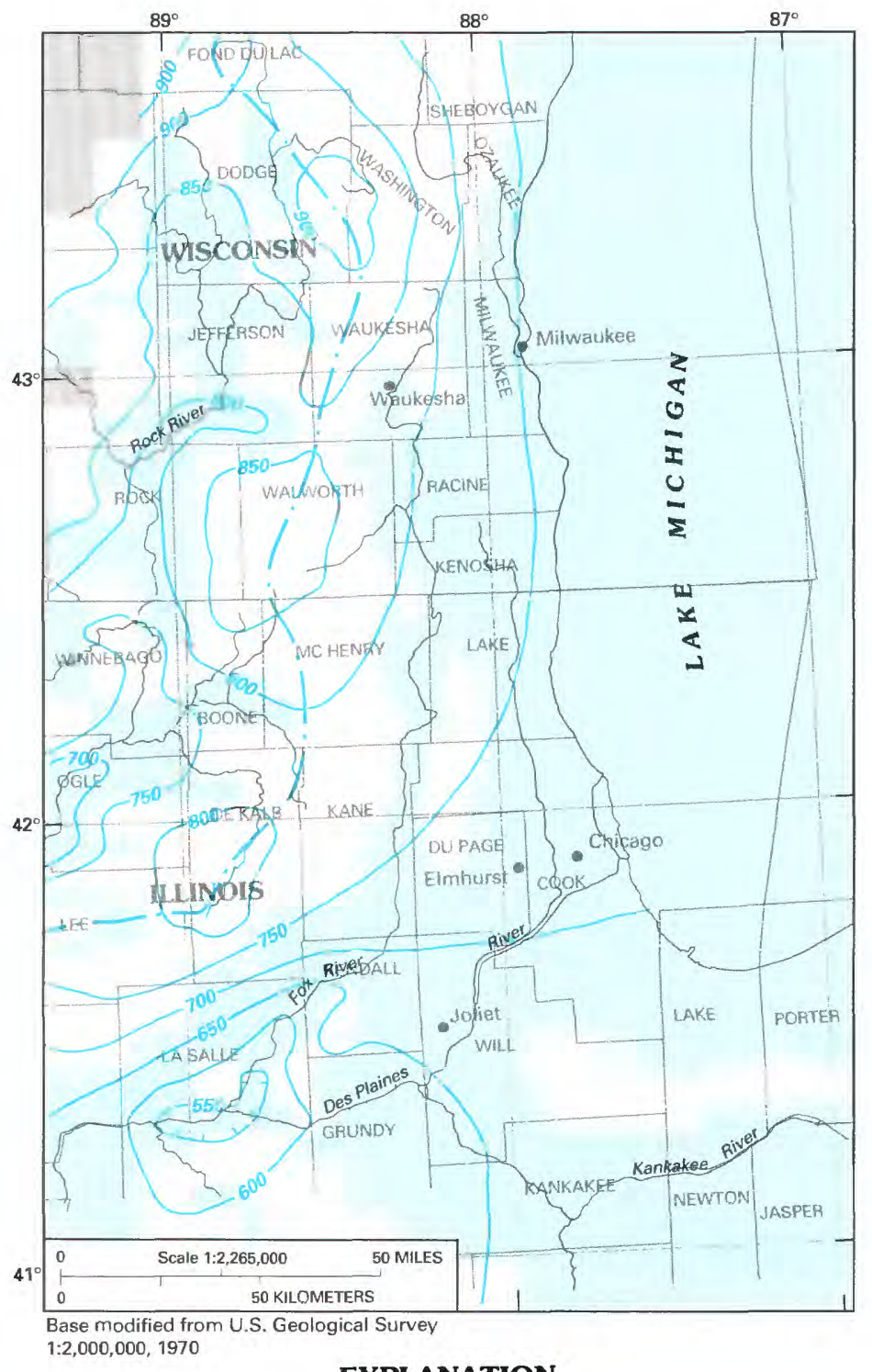

EXPLANATION

POTENTIOMETRIC CONTOUR - Shows simulated predevelopment head in the St. Peter-Prairie du Chien-Jordan aquifer. Hachures indicate area of lower head. Contour interval 50 feet. Datum is sea level

\section{POTENTIOMETRIC DIVIDE}

\section{AQUIFER ABSENT}

DIRECTION OF SIMULATED VERTICAL FLOW THROUGH THE TOP OF THE AQUIFER

Upward

Downward

FiguRE 30.-Simulated predevelopment head and vertical flow direction in the St. Peter-Prairie du Chien-Jordan aquifer in the Chicago-Milwaukee area. (From H.L. Young and A.J. MacKenzie, U.S. Geological Survey, written commun., 1988.) 
along the major potentiometric divide to the west. These conditions of high head were shown by the many flowing wells drilled during the late 1800 's.

Rates of simulated steady-state horizontal flow within the Cambrian- Ordovician aquifers, represented as specific discharge or Darcian flow, ranged from less than 1 to more than $50 \mathrm{in} / \mathrm{yr}$ (inches per year). The rates generally were less than $10 \mathrm{in} / \mathrm{yr}$ in the confined aquifer system and decreased to the east-the direction of ground-water movement and structural dip of the rocks (fig. 11). Rates were lowest in the Mount Simon aquifer, and were highest in the unconfined areas where hydraulic gradients steepen and the aquifers are relatively thin.

The simulated steady-state potentiometric surface of the St. Peter-Prairie du Chien-Jordan aquifer was used to subdivide the almost-71,000- $\mathrm{mi}^{2}$ modeled area into three zones, representing areas of major flow systems, to provide a better framework for analysis of modeled hydrologic budget components. One zone is an area of about $17,100 \mathrm{mi}^{2}$ that encompasses deeply confined flow in the Michigan basin to the east. Its hydrologic budget is not important to the study, but, for modeling purposes, the area is a necessary extension of the confined aquifer system beyond the Chicago-Milwaukee area. Two flow systems account for the balance of the modeled area. One consists of about $6,800 \mathrm{mi}^{2}$ of the Rock River basin west of the potentiometric divide shown in figure 30 . The model study focused on the Cambrian-Ordovician aquifer system in the remaining $47,100 \mathrm{mi}^{2}$ to the east of the divide, which includes all the area affected by ground-water withdrawal in the Chicago-Milwaukee area. This area is referred to subsequently in this report as the Chicago-Milwaukee area flow system. The Cambrian-Ordovician aquifer system generally is overlain by the Maquoketa confining unit in that area, but is mainly unconfined or semiconfined in the Rock River basin to the west.

The steady-state simulation indicates that most predevelopment recharge and discharge of the CambrianOrdovician aquifer system in the Chicago-Milwaukee area flow system was directly between the drift aquifer and the St. Peter-Prairie du Chien-Jordan aquifer where the Maquoketa confining unit is absent (on the western side of the area, fig. 30). The boundary of the ChicagoMilwaukee area flow system, as delineated in the model, is not a pure zero-flux boundary, and a small amount of horizontal flow across the boundary is not accounted for. Recharge there averaged about $31.4 \mathrm{ft}^{3} / \mathrm{s}(0.47 \mathrm{in} / \mathrm{yr})$ through an area of $899 \mathrm{mi}^{2}$ (fig. 31), and discharge averaged $32.0 \mathrm{ft}^{3} / \mathrm{s}(0.86 \mathrm{in} / \mathrm{yr})$ through $506 \mathrm{mi}^{2}$. An additional $16.4 \mathrm{ft}^{3} / \mathrm{s}(0.18 \mathrm{in} / \mathrm{yr})$ entered the aquifer through the Maquoketa confining unit, where it is partly eroded and thin, over an area of 1,261 $\mathrm{mi}^{2}$. Discharge under these conditions over an area of $1,269 \mathrm{mi}^{2}$ was 9.81 $\mathrm{ft}^{3} / \mathrm{s}(0.10 \mathrm{in} / \mathrm{yr})$. The simulation shows that $4.93 \mathrm{ft}^{3} / \mathrm{s}$ (0.003 in/yr) flowed downward through the confining unit where it is overlain by the Silurian-Devonian aquifer, an area of $23,975 \mathrm{mi}^{2}$. The size of the downward flow area is deceptive compared to the area in figure 30 , because $11,770 \mathrm{mi}^{2}$ is in areas of very low rates of downward flow in the extreme southwestern and southeastern parts of the model grid, outside the area of figure 30. Upward discharge through the Maquoketa confining unit over an area of $19,175 \mathrm{mi}^{2}$ averaged $11.3 \mathrm{ft}^{3} / \mathrm{s}(0.008 \mathrm{in} / \mathrm{yr})$.

$$
\text { Transient Simulation }
$$

The calibrated steady-state model was the basis for a transient model, which simulates the entire period of development of the Cambrian-Ordovician aquifer system, from 1864 to 1985 , in 13 stress periods. Calibration was achieved by adjusting hydraulic characteristics to obtain a reasonable match of simulated and measured potentiometric heads at the respective dates 1961, 1980, and 1985. In addition, comparison of simulated heads with long-term well hydrographs at several locations gave an indication of the cumulative accuracy of the simulation over time. The potentiometric surface derived from simulated 1985 composite heads in the aquifer system (fig. 32) closely matches the potentiometric surface derived from measured water levels, most of which are for multiaquifer wells.

Development of ground water from the aquifer system where it is confined has produced very large head declines, as previously described and shown in figure 23 , that are centered on the major areas of withdrawal at Chicago and Milwaukee. The shape of the resultant cones of depression in the composite potentiometric surface (fig. 32) is a good example of boundary effects and the spread of drawdown in a confined aquifer. The steepening of the western side of the cone near the recharge areas on the west results from relatively high rates of vertical leakage in the recharge areas. Conversely, the eastern side of the cone slopes gently to the east away from the recharge areas, where vertical leakage is limited by the thick Maquoketa confining unit and by the very small vertical head gradients. Drawdown there is smaller, but more widespread, to satisfy the withdrawal rates in the cones.

Development of the large cones of depression has changed the directions of ground-water movement greatly. The major changes are the reversal of the original horizontal flow to the east and southeast toward the Michigan and Illinois basins and the reversal of the upward flow out of the Cambrian-Ordovician aquifer system through the Maquoketa confining unit near Lake Michigan. Within the Chicago-Milwaukee area flow sys- 


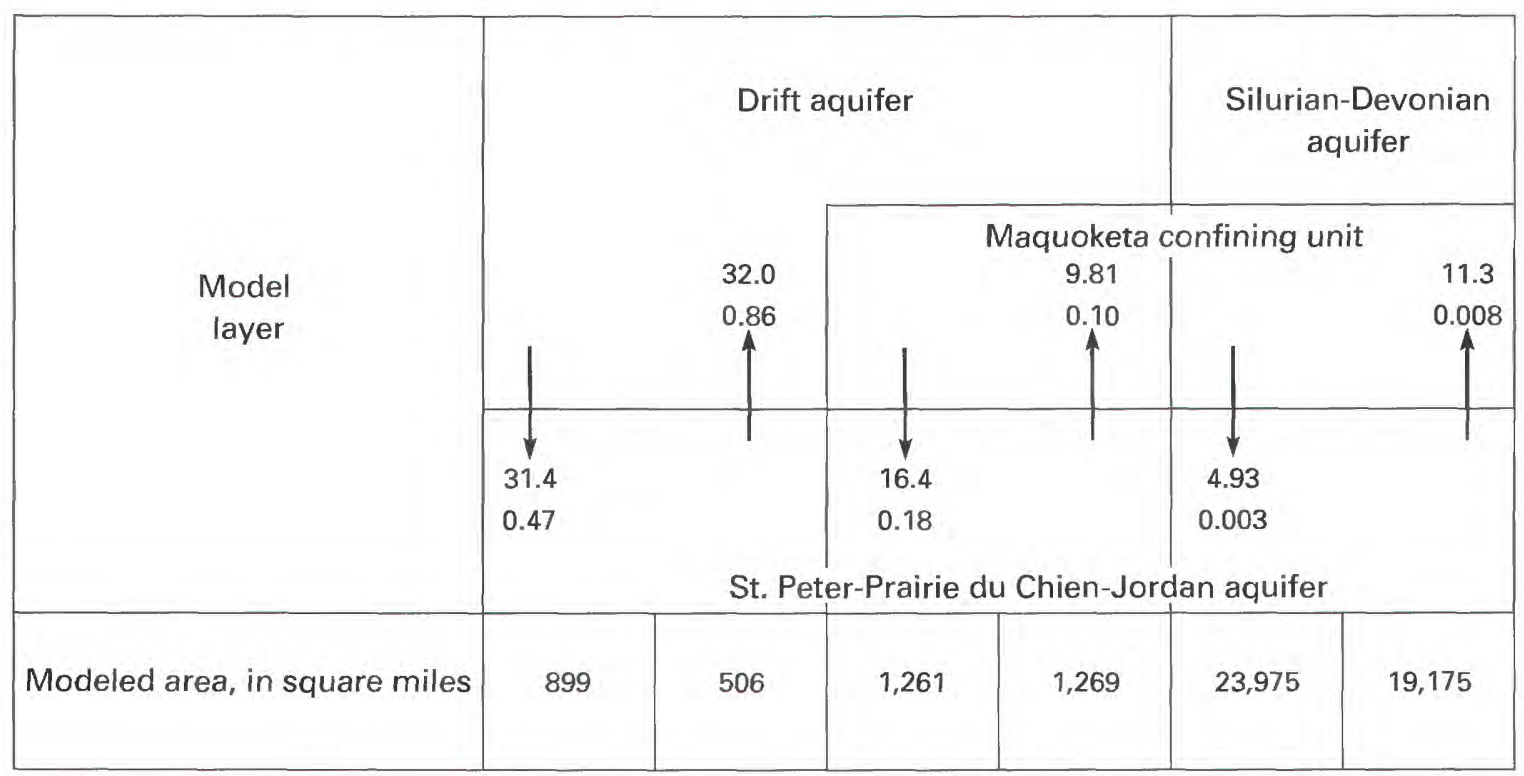

\section{EXPLANATION}
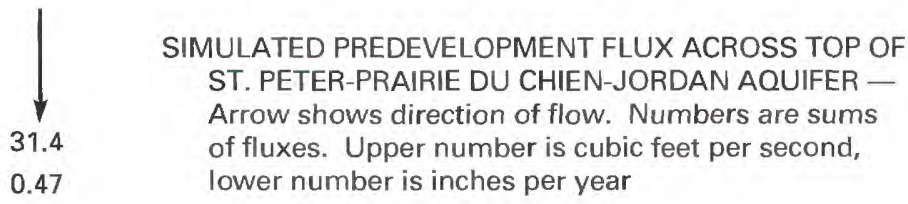

FIGURE 31.-Simulated predevelopment ground-water flow across the top of the St. Peter-Prairie du Chien-Jordan aquifer within the area of the Chicago-Milwaukee flow system. (From H.L. Young and A.J. MacKenzie, U.S. Geological Survey, written commun., 1988.)

tem, upward flow now occurs only on the extreme perimeter of the area to the north and southwest (fig. 32).

Less obvious are the changes caused by the shifting of potentiometric divides. The simulation shows that the location of the major north-south divide (fig. 30), which defines the western limit of the Chicago-Milwaukee flow system, probably has moved westward about $10 \mathrm{mi}$ in northwestern Waukesha and southeastern Dodge Counties, Wis., and as much as $20 \mathrm{mi}$ in southern Boone and northern De Kalb Counties, Ill. (fig. 32). The lack of historical water-level data precludes accurate determination of the position of the predevelopment divide. The only long-term data relating to the position of the divide are the water-level records for an observation well in the St. Peter-Prairie du Chien-Jordan aquifer near the western line of Waukesha County (fig. 33). Water-level measurements from 1946 to 1987 seem to show a slight downward trend-perhaps $5 \mathrm{ft}$ of decline over the 41 years. Simulated total head decline in that aquifer as of 1985 also was about $5 \mathrm{ft}$, but in the underlying Ironton-
Galesville and Mount Simon aquifers the declines were about $30 \mathrm{ft}$. The larger declines in the underlying aquifers can be explained by the fact that the lower aquifers are well confined throughout the study area and in all of southern Wisconsin and northern Illinois, whereas the St. Peter-Prairie du Chien-Jordan aquifer is unconfined in the general area of the divide and farther to the west.

Comparison of simulated 1985 flow into and out of the aquifer system in the main Chicago-Milwaukee area flow system (fig. 34) with those for predevelopment conditions (fig. 31) shows very large changes caused by the head decline. Downward flow across the Maquoketa confining unit increased by about $82 \mathrm{ft}^{3} / \mathrm{s}$, and upward flow decreased by about $14 \mathrm{ft}^{3} / \mathrm{s}$; downward flow from the drift aquifer increased by about $42 \mathrm{ft}^{3} / \mathrm{s}$, and discharge to the drift decreased by about $23 \mathrm{ft}^{3} / \mathrm{s}$. This is a net increase of about $161 \mathrm{ft}^{3} / \mathrm{s}$. The rates of upward discharge per unit area (shown in fig. 31 as inches per year) were about the same, but the areas decreased greatly because of flow reversal. Both the rates per unit area and the areas of downward flow are much larger for 1985 than for 


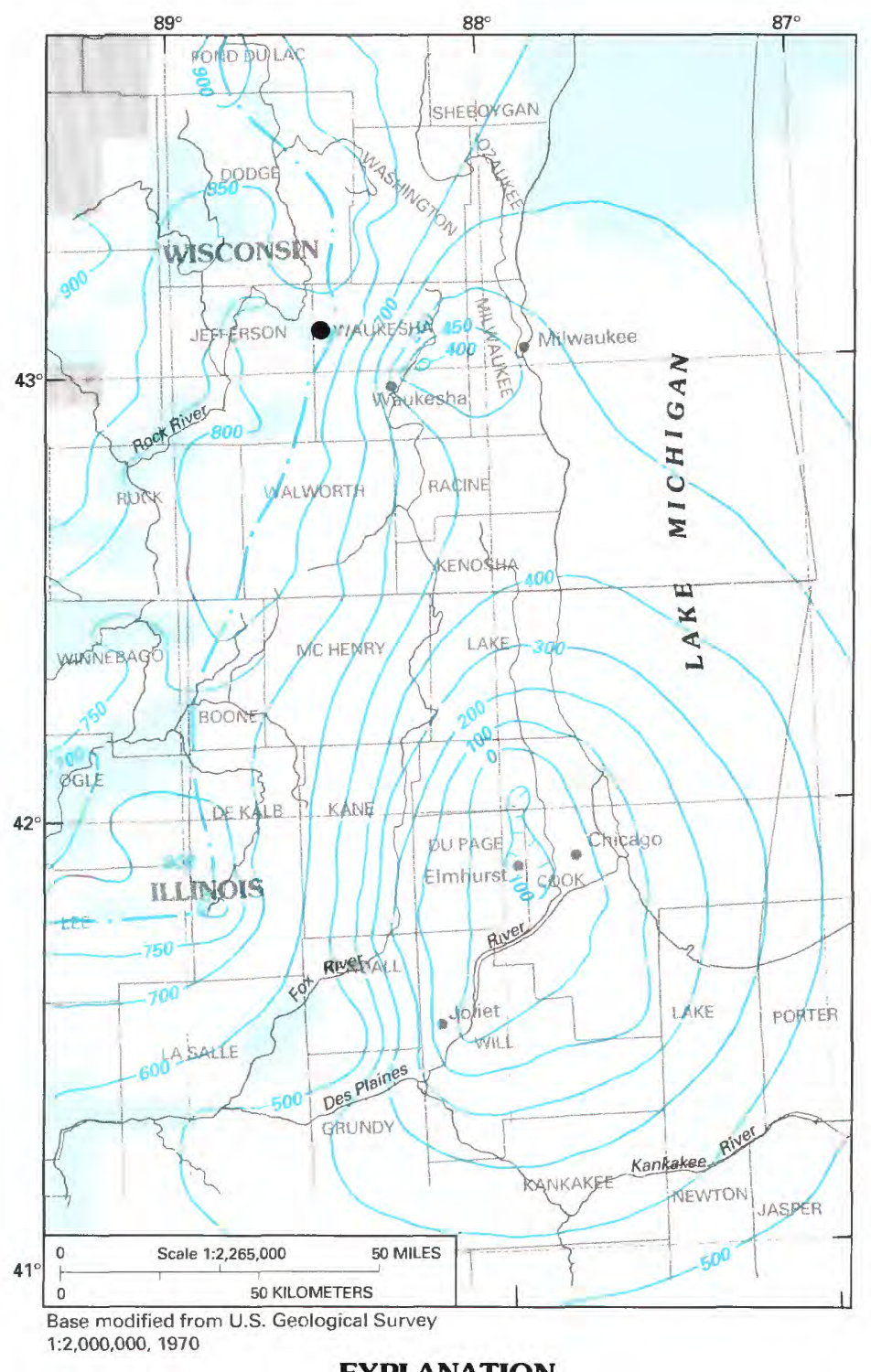

EXPLANATION

FIgURE 32.-Simulated 1985 head and vertical flow direction in the composite Cambrian-Ordovician aquifer system in the Chicago-Milwaukee area. (From H.L. Young and A.J. MacKenzie, U.S. Geological Survey, written commun., 1988.)
POTENTIOMETRIC CONTOUR - Shows simulated 1985 head in the composite Cambrian-Ordovician aquifer system. Hachures indicate area of lower head. Contour interval, in feet, is variable. Datum is sea level

POTENTIOMETRIC DIVIDE

AQUIFER ABSENT

DIRECTION OF SIMULATED VERTICAL FLOW THROUGH THE TOP OF THE AQUIFER SYSTEM

Upward

Downward

LOCATION OF WELL WK-07/17E/05-0020 - Hydrograph in figure 33 


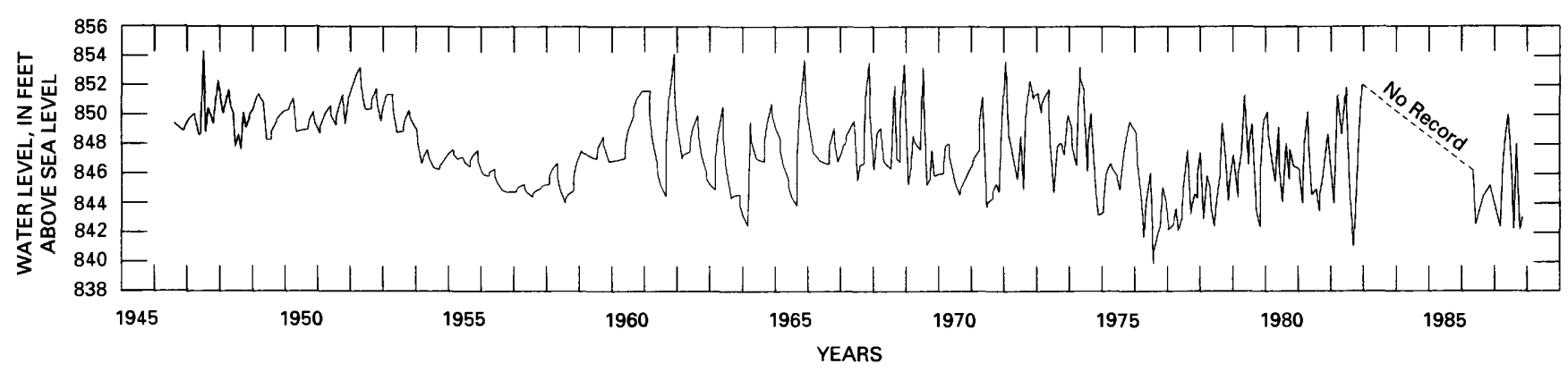

FIGURE 33. - Hydrograph for well Wk-07/17E/05-0020 completed in the St. Peter-Prairie du Chien-Jordan aquifer in northwestern Waukesha County, Wisconsin. (Location shown in fig. 32. From H.L. Young and A.J. MacKenzie, U.S. Geological Survey, written commun., 1988.)

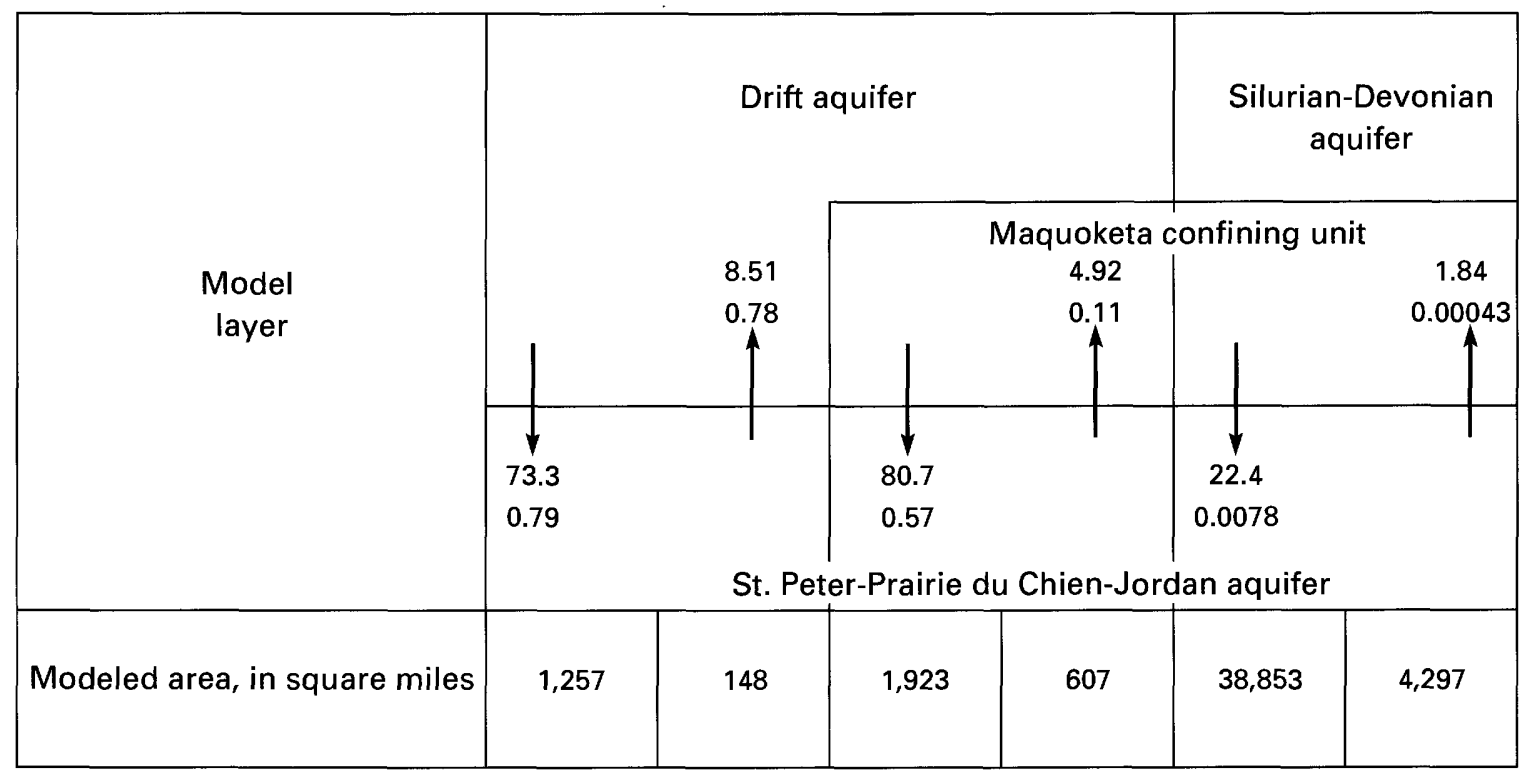

\section{EXPLANATION}

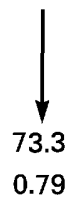

SIMULATED 1985 FLUX ACROSS TOP OF ST. PETER-PRAIRIE DU CHIEN-JORDAN AQUIFER -

Arrow shows direction of flow. Numbers are sums of fluxes. Upper number is cubic feet per second, lower number is inches per year

FIGURE 34. - Simulated 1985 ground-water flow across the top of the St. Peter-Prairie du Chien-Jordan aquifer within the area of the Chicago-Milwaukee flow system. (From H.L. Young and A.J. MacKenzie, U.S. Geological Survey, written commun., 1988.)

the predevelopment simulation. Average pumpage from the Cambrian-Ordovician aquifers in the ChicagoMilwaukee area flow system was about $322 \mathrm{ft}^{3} / \mathrm{s}(208$ $\mathrm{Mgal} / \mathrm{d}$ ) for the period 1981-85. Contribution from storage during this period accounted for about $116 \mathrm{ft}^{3} / \mathrm{s}$, and net increase from vertical flow was $161 \mathrm{ft}^{3} / \mathrm{s}$, leaving a difference of about $45 \mathrm{ft}^{3} / \mathrm{s}$, which is induced flow within the aquifer system from the extended cone of depression west of the original potentiometric divide.

The indication that the major cones of depression have extended westward beyond the original potentiometric divide, especially within the fully confined IrontonGalesville and Mount Simon aquifers, is a significant finding of this simulation of the Chicago-Milwaukee area. 
Fortunately, little extension of the cones of depression is apparent in the St. Peter-Prairie du Chien-Jordan and drift aquifers, which are shallower and are under watertable conditions.

\section{TOPICS FOR FURTHER INVESTIGATION}

A number of areas of investigation warrant consideration in planning further studies of the CambrianOrdovician aquifer system in the northern Midwest. Those discussed here are related primarily to the occurrence and quality of ground water in heavily pumped areas in the confined parts of the aquifer system.

Confining units are important controlling factors in the regional flow system; thus, knowledge of their hydraulic properties and leakage capability, which affect water quality and quantity in adjacent aquifers, needs to be improved. Although the rate per unit area is small, induced transient leakage from a confining unit can be a major part of the volume of water released from storage during pumping of a confined aquifer because of the size of the confined area and the thickness of the confining unit. Ground water in confining units generally is of a different quality, commonly containing more dissolved solids than that in nearby aquifers, and its movement into these aquifers can alter water quality in the aquifers.

\section{HYDRAULIC CHARACTERISTICS OF CONFINING UNITS}

Vertical hydraulic conductivity and specific storage of confining units are the properties that are the most difficult to determine and generally are estimated. It is likely that vertical openings, such as joints and fractures, rather than the permeability of the solid, unfractured rock, account for much of the regional leakage through shale confining units. Detailed research on the confining units of the aquifer system is needed, similar in scope to the field and simulation studies by Bredehoeft and others (1983) of the effects of confining units on the Dakota aquifer in South Dakota. Data on the Maquoketa Shale and the underlying Galena-Platteville unit are especially important. The Galena-Platteville unit is known to be more of a confining unit than an aquifer where overlain by the Maquoketa, but its transition into a moderately productive, unconfined aquifer where the Maquoketa is absent has not been quantified. The lithostratigraphy of the Maquoketa in Iowa, northern Illinois, and Indiana has been studied in some detail (Parker, 1971; Gray, 1972; Kolata and Graese, 1983), as has the GalenaPlatteville unit in northern Illinois (Willman and Kolata, 1978). However, facies maps of the Maquoketa in eastern Wisconsin are not available.
The Mount Simon Sandstone in southeastern Wisconsin, northeastern Illinois, and northwestern Indiana contains much interbedded siltstone and shale, especially in the upper part of the formation. The extent and confining properties of these units have not been studied. A 500 -ft-thick zone containing interbedded shales begins about $100 \mathrm{ft}$ below the top of the Mount Simon in the 3,475-ft-deep test well at Zion, Ill. (Nicholas and others, 1987). Water-level measurements from packer tests and deep piezometers installed in the well show that the present hydraulic head is about $50 \mathrm{ft}$ higher beneath the zone than above. The concentration of chloride in the ground water yielded during the air-rotary drilling process increased sharply as this zone was penetrated. The confinement by this zone undoubtedly controls the vertical distribution of saline water in the Mount Simon aquifer in the Chicago area. Historical records indicate that many wells originally drilled into the Mount Simon there have been backfilled to eliminate flow of saline water from that aquifer. Also, several deep wells in the Mount Simon in north-central Illinois and northwestern Indiana are used for disposal of liquid wastes. Therefore, knowledge of the extent and characteristics of this interbedded shale zone is important for future groundwater development and disposal of liquid wastes in these areas.

\section{RELATION OF CONFINING UNITS TO WATER QUALITY}

Back (1985) described the influence of confining units on aquifer geochemistry and pointed to the need for development of special techniques for collecting and interpreting data from confining units. Shales and siltstones are particularly important vehicles for waterquality change because of the susceptibility to solution and chemical reaction of their very small sediment particles and component mineral species. The particles in rocks of these types are dominantly clay minerals and quartz, but they contain variable amounts of other minerals, such as feldspar, mica, chlorite, pyrite, hydrated oxides of iron or aluminum, glauconite, or other minor minerals. Ground water readily dissolves or reacts with these minerals, thereby affecting the chemistry of water in confining units.

Ground-water quality also is believed to be altered by the selective ion filtration processes of chemical osmosis and reverse chemical osmosis by shale or clay layers that function as a semipermeable membrane, and by ion exchange with the clay minerals in shales. As summarized by Hanor (1983), these processes and others have been invoked by various investigators to explain the origin of brines in sedimentary basins.

The major concerns about water quality in the Cambrian-Ordovician aquifer system are the occurrences 
of excessive radium concentrations and saline water. These are characteristics of the aquifer system primarily where it is confined by the Maquoketa, but high dissolved-solids concentrations also are present at depth along the Mississippi River valley and in areas of eastern Wisconsin just west of the western edge of the Maquoketa. Levels of radium that exceed the current primary drinking-water standard of $5 \mathrm{pCi} / \mathrm{L}$ (picocuries per liter) (U.S. Environmental Protection Agency, 1986) have been reported for water from many wells in the confined aquifer system in Iowa, northern Illinois, and eastern Wisconsin. The widespread occurrence of radium is not everywhere directly correlated with salinity; however, water salinity usually is directly related to radium concentrations. Field studies are needed to determine the exact source(s) of the radium within the aquifer system and the relation to the Maquoketa confining unit.

\section{OTHER TOPICS}

Other subjects related to the Cambrian-Ordovician aquifer system that need to be studied include the following:

- Effects on, and contribution to, discharge from multiaquifer wells and interformational flow by the SilurianDevonian aquifer in eastern Wisconsin and northeastern Illinois.

- Changes in water quality in the Cambrian-Ordovician aquifer system within the heavily pumped areas in eastern Wisconsin and northeastern Illinois during the past 60 years or so since reversal of the upward head gradient across the Maquoketa.

- Field delineation of potentiometric divides in individual aquifers west of the cones of depression in eastern Wisconsin and northeastern Illinois.

- The possibility of artificial recharge of the aquifer system in the Chicago area, suggested or proposed by Foley and Smith (1954), Suter and others (1959), Schicht and others (1976), and Bennett and others (1982).

- Effects on the regional flow system of major structural features, such as the Sandwich fault zone and La Salle anticline in northern Illinois and the Plum River fault zone of eastern Iowa.

- The role of ground water in the deposition of the Mississippi Valley-type ore deposits in southwestern Wisconsin and northwestern Illinois.

\section{CONCLUSIONS}

The Cambrian-Ordovician aquifer system is a very important regional resource in the northern Midwest. It provided about $680 \mathrm{Mgal} / \mathrm{d}$ of the ground-water needs to parts of Illinois, Iowa, Minnesota, Missouri, and Wisconsin in 1980 . About $180 \mathrm{Mgal} / \mathrm{d}$ was pumped in each of the metropolitan areas of Chicago and Minneapolis-St. Paul.

The aquifer system is composed of the entire thick and areally extensive sequence of Cambrian and Ordovician sandstone, siltstone, dolomite, and shale in the northern Midwest. Three aquifers, composed mainly of sandstone, are recognized in the aquifer system; the aquifers are separated by confining units. The major hydrogeologic units are the Maquoketa confining unit (the uppermost part of the aquifer system) and, in descending order, the St. Peter-Prairie du Chien-Jordan, Ironton-Galesville, and Mount Simon aquifers. The Cambrian and Ordovician strata dip gently off the elevated Precambrian basement of northern Minnesota and Wisconsin toward structural basins to the south and east.

Unconfined conditions prevail in the aquifer system in its northern outcrop area in the shallow parts of the aquifer system and where it is thin. Leaky-artesian conditions generally prevail elsewhere in the aquifer system.

Ground water moves in the aquifer system within flow systems of different areal and subsurface extent. Much of the ground-water recharge in upland areas discharges to streams through local, unconfined flow systems that are no more than a few miles in length. This flow is a large part of the overall volume of recharge and discharge in the study area. The remainder of the recharge moves slowly downward to deeper formations and downgradient to form or join the regional flow system. This deeper flow occurs within intermediate- or regional-scale flow systems toward the structural basins in the south and east. The rate of flow is very small and decreases progressively downgradient because of head loss from upward leakage through confining units. Saline water within the structural basins restricts movement of freshwater into the deeper parts of the basins; thus, the water is forced upward.

Principal regional discharge areas are the Mississippi and Missouri Rivers, the Illinois and Michigan basins, and Lake Michigan. However, the lake is not in direct hydraulic connection with the Cambrian-Ordovician aquifer system; rather, it receives flow from the SilurianDevonian aquifer, which directly underlies the lake and receives upward leakage from the Cambrian-Ordovician aquifer system.

The first deep wells were drilled into the aquifer system in the 1860 's. Many were flowing artesian wells located near Lake Michigan in eastern Wisconsin and northeastern Illinois, and along the Mississippi River valley and its tributaries. Initial heads of 186 and $130 \mathrm{ft}$ above Lake Michigan were reported at Milwaukee and Chicago, respectively. 
High rates of pumping from the aquifer system have caused large head declines and extensive cones of depression. The largest head declines are in areas where the aquifer system is well confined-as much as $900 \mathrm{ft}$ at Chicago, $375 \mathrm{ft}$ at Milwaukee, and more than $200 \mathrm{ft}$ at Mason City, Iowa, and the Quad Cities of Iowa and Illinois by 1980, and $440 \mathrm{ft}$ at Green Bay, Wis., by 1957 . However, the head decline in the upper, unconfined part of the aquifer system in Minneapolis-St. Paul was only 90 ft by 1980 .

Computer simulations of the regional ground-water flow system were made to approximate the predevelopment head in 1864 and to evaluate the flow system under both steady-state and transient conditions. The transient simulation through 1980 depicts the large water-level declines in the confined parts of the CambrianOrdovician aquifer system in Iowa, eastern Wisconsin, northeastern Illinois, and north-central Missouri and the associated changes in direction of ground-water movement. Ground-water withdrawals caused little change in the unconfined parts of the flow system. The simulation shows that total recharge to the aquifer system increased by $692 \mathrm{ft}^{3} / \mathrm{s}$ from predevelopment conditions to a total of $1,236 \mathrm{ft}^{3} / \mathrm{s}$ in 1980 . Natural discharge decreased by 153 $\mathrm{ft}^{3} / \mathrm{s}$, to a total of $391 \mathrm{ft}^{3} / \mathrm{s}$, and $212 \mathrm{ft}^{3} / \mathrm{s}$ was released from aquifer storage.

A subregional simulation of the Cambrian-Ordovician aquifer system in the Chicago-Milwaukee area shows the effects of development there in more detail. The original artesian conditions caused upward flow from the aquifer system through the Maquoketa confining unit into the overlying Silurian-Devonian aquifer near Lake Michigan. However, by the 1920's in the areas of greatest head decline, the head in the aquifer system had begun to decline below that in the Silurian-Devonian aquifer. This head reversal caused the vertical flow to reverse, being induced downward across the Maquoketa. By 1985, the area of downward flow across the Maquoketa had increased to encompass most of the Chicago-Milwaukee area affected by pumping. A potentiometric divide that bounds the Chicago-Milwaukee area flow system on the west apparently has shifted westward as much as $20 \mathrm{mi}$ in response to the expanding cones of depression. Downward flow across the Maquoketa in the ChicagoMilwaukee area flow system increased by $64 \mathrm{ft}^{3} / \mathrm{s}$ from predevelopment conditions to a total of $81 \mathrm{ft}^{3} / \mathrm{s}$ in 1985 , and recharge to the aquifer system from the overlying drift aquifer increased by $42 \mathrm{ft}^{3} / \mathrm{s}$ to a total of $73 \mathrm{ft}^{3} / \mathrm{s}$. Natural discharge decreased by $38 \mathrm{ft}^{3} / \mathrm{s}$ to a total of 15 $\mathrm{ft}^{3} / \mathrm{s}$ in 1985.

Ground water in the Cambrian-Ordovicican aquifer system is characterized by an extreme range of mineralization and chemical types, but its quality is good and suitable for most uses in most of the study area.
Dissolved-solids concentrations generally are low (less than $500 \mathrm{mg} / \mathrm{L}$ ) in the recharge areas in the northern and central parts of the area and are high (brines containing as much as $200,000 \mathrm{mg} / \mathrm{L}$ ) in the structural basins to the south and east. The water in the Cambrian-Ordovician aquifer system in most of the unconfined areas is a calcium magnesium bicarbonate type and is similar in quality in each of the aquifers.

Water quality in the confined parts of the aquifer system is much more variable. Concentrations of dissolved solids and the major ions in most places increase in direct proportion to the distance the water has traveled from areas of recharge. Transition to higher dissolved solids in the confined areas commonly is accompanied by substantial increases in sulfate concentration and the presence of calcium sodium sulfate-type water.

The residual effects on ground-water quality from continental glaciations during the Pleistocene are indicated by isotopic analysis of the ground water. Depletion of the oxygen-18 isotope in water indicates that the source of much of the ground water in the confined areas was subglacial recharge of meltwater during the Pleistocene. Effects from loading by Pleistocene ice sheets may be shown by the positive $\delta^{34} \mathrm{~S}$ values for sulfur in sulfate in saline water near Lake Michigan in eastern Wisconsin and northeastern Illinois. It is believed that isostatic loading from glacial ice over the Michigan basin created a westward hydraulic gradient, opposite from the natural eastward gradient that prevailed prior to development in the Chicago-Milwaukee area. This flow reversal by ice loading caused saline water from the Michigan basin, which contained sulfate with sulfur of an evaporitic origin, to flow westward and discharge through the present recharge areas.

Important research topics for future studies include the hydraulic characteristics and geochemical control of confining units in the Cambrian-Ordovician aquifer system, especially for the Maquoketa confining unit and a local confining unit in the upper part of the Mount Simon aquifer in the Chicago-Milwaukee area.

\section{REFERENCES CITED}

Ackermann, W.C., and others, 1974, Feasibility study on desalting brackish water from the Mt. Simon aquifer in northeastern Illinois: U.S. Department of the Interior, Office of Saline Water, Research and Development Progress Report 938 and Illinois State Water Survey Contract Report 153, 120 p.

Alexander, E.C., Jr., Siegel, D.I., and Milske, J.A., 1983, Isotopic studies of the Mt. Simon aquifer, southern Minnesota [abs.]: American Geophysical Union Transactions, EOS, v. 64, no. 18, p. 225.

Back, William, 1966, Hydrochemical facies and ground-water flow patterns in northern part of Atlantic Coastal Plain: U.S. Geological Survey Professional Paper 498-A, p. 1-42. 
1985, Geochemical significance of aquitards, in Hydrogeology of rocks of low permeability: International Association of Hydrogeologists Congress, 17th, Tucson, Ariz., 1985, Memoirs, v. 17, pt. 1, p. $358-369$.

Bennett, G.D., 1979, Regional ground-water systems analyses: Water Spectrum, v. 11, no. 4.

Bennett, Truman, Gass, T.E., Lehr, J.H., Aller, Linda, and Nielsen, D.M., 1982, A cost effective water supply alternative for the Chicago suburban area: Artificial ground-water recharge: National Water Well Association research paper, $70 \mathrm{p}$.

Bond, D.C., 1972, Hydrodynamics in deep aquifers of the Illinois basin: Illinois State Geological Survey Circular 470, $72 \mathrm{p}$.

Bredehoeft, J.D., Neuzil, C.E., and Milly, P.C.D., 1983, Regional flow in the Dakota aquifer: A study of the role of confining layers: U.S. Geological Survey Water-Supply Paper 2237, $45 \mathrm{p}$.

Burkart, M.R., and Buchmiller, R.C., in press, Regional aquifer evaluation of hydrologic factors and effects of pumping, St. PeterJordan aquifer, Iowa: U.S. Geological Survey Water-Resources Investigations Report 90-4009.

Delin, G.N., and Woodward, D.G., 1984, Hydrogeologic setting and the potentiometric surfaces of regional aquifers in the Hollandale embayment, southeastern Minnesota, 1970-80: U.S. Geological Survey Water-Supply Paper 2219, 56 p.

Emmons, P.J., 1987, An evaluation of the bedrock aquifer system in northeastern Wisconsin: U.S. Geological Survey Water-Resources Investigations Report 85-4199, $48 \mathrm{p}$.

Fetter, C.W., Jr., 1981, Interstate conflict over ground water: Wisconsin-Illinois: Ground Water, v. 19, no. 2, p. 201-213.

Foley, F.C., and Smith, H.F., 1954, Ground-water recharge of a deeply buried artesian aquifer in Illinois and Wisconsin, U.S.A.: International Association of Scientific Hydrology Publication 37, pt. 2, p. 225-231.

Foley, F.C., Walton, W.C., and Drescher, W.J., 1953, Ground-water conditions in the Milwaukee-Waukesha area, Wisconsin: U.S. Geological Survey Water-Supply Paper 1229, 96 p.

Freeze, R.A., and Witherspoon, P.A., 1967, Theoretical analysis of regional groundwater flow: 2 . Effect of water table configuration and subsurface permeability variation: Water Resources Research, v. 3, no. 2, p. 623-634.

Gilkeson, R.H., Cartwright, Keros, Cowart, J.B., and Holtzman, R.B., 1983, Hydrogeologic and geochemical studies of selected natural radioisotopes and barium in groundwater in Illinois: University of Illinois Water Resources Center Report 83-0180, Illinois State Geological Survey Contract/Grant Report 1983-6, 93 p.

Gilkeson, R.H., Perry, E.C., Jr., Cowart, J.B., and, Holtzman, R.B., 1984, Isotopic studies of the natural sources of radium in groundwater in Illinois: University of Illinois Water Resources Center Research Report 84-187, $50 \mathrm{p}$.

Graf, D.L., 1982, Chemical osmosis, reverse chemical osmosis, and the origin of subsurface brines: Geochimica et Cosmochimica Acta, v. 46, p. $1431-1448$.

Gray, H.H., 1972, Lithostratigraphy of the Maquoketa Group (Ordovician) in Indiana: Indiana Geological Survey Special Report 7, $31 \mathrm{p}$.

Guswa, J.H., Siegel, D.I., and Gillies, D.C., 1982, Preliminary evaluation of the ground-water-flow system in the Twin Cities metropolitan area, Minnesota: U.S. Geological Survey Water-Resources Investigations Report 82-44, 65 p.

Hahn, N.A., Jr., 1984, Radium in Wisconsin groundwater and removal methods for community water systems: Madison, Wisconsin Department of Natural Resources, $125 \mathrm{p}$.

Hanor, J.S., 1983, Fifty years of development of thought on the origin and evolution of subsurface sedimentary brines, in Boardman, S.J., ed., Revolution in the earth sciences: Dubuque, Iowa, Kendall/Hunt, 385 p.
Horick, P.J., 1984, Silurian-Devonian aquifer of Iowa: Iowa Geological Survey Miscellaneous Map Series 10, 4 sheets.

Horick, P.J., and Steinhilber, W.L., 1973, Mississippian aquifer of Iowa: Iowa Geological Survey Miscellaneous Map Series 3, 3 sheets.

1978, Jordan aquifer of Iowa: Iowa Geological Survey Miscellaneous Map Series 6, 3 sheets.

Horn, M.A., 1983, Ground-water-use trends in the Twin Cities metropolitan area, 1880-1980: U.S. Geological Survey Water-Resources Investigations Report 83-4033, $37 \mathrm{p}$.

Imes, J.L., 1985, The ground-water flow system in northern Missouri, with emphasis on the Cambrian-Ordovician aquifer: U.S. Geological Survey Professional Paper 1305, $61 \mathrm{p}$.

Jorgensen, D.G., and Signor, D.C., 1981, Plan of study for the Central Midwest Regional Aquifer-System Analysis in parts of Arkansas, Colorado, Kansas, Missouri, Nebraska, New Mexico, South Dakota, and Texas: U.S. Geological Survey Water-Resources Investigations Report 81-206, $28 \mathrm{p}$.

Kammerer, P.A., Jr., 1984, An overview of ground-water quality in Wisconsin: U.S. Geological Survey Water-Resources Investigations Report 83-4239, $58 \mathrm{p}$.

Kirk, J.R., Jarboe, Jacquelyn, Sanderson, E.W., Sasman, R.T., and Lonnquist, C.G., 1982, Water withdrawals in Illinois, 1980: Illinois State Water Survey Circular 152, $47 \mathrm{p}$.

Kolata, D.R., and Graese, A.M., 1983, Lithostratigraphy and depositional environments of the Maquoketa Group (Ordovician) in northern Illinois: Illinois State Geological Survey Circular 528, $49 \mathrm{p}$.

Kontis, A.L., and Mandle, R.J., 1980, Data-base system for Northern Midwest Regional Aquifer-System Analysis: U.S. Geological Survey Water-Resources Investigations Report 80-104, 23 p.

1988, Modifications of a three-dimensional ground-water flow model to account for variable water density and effects of multiaquifer wells: U.S. Geological Survey Water-Resources Investigations Report 87-4265, $78 \mathrm{p}$.

Krohelski, J.T., 1986, Hydrogeology and ground-water use and quality, Brown County, Wisconsin, with a section on bedrock geology by Bruce A. Brown: Wisconsin Geological and Natural History Survey Information Circular 57, $42 \mathrm{p}$.

Macaitis, Bill, Povilaitis, S.J., and Cameron, E.B., 1977, Lake Michigan diversion-stream quality planning: Water Resources Bulletin, v. 13 , no. 4 , p. $795-805$.

Mandle, R.J., and Kontis, A.L., in press, Simulation of regional ground-water flow in the Cambrian-Ordovician aquifer system in the northern Midwest, United States: U.S. Geological Survey Professional Paper 1405-C.

McLeod, R.S., 1975a, A digital-computer model for estimating drawdowns in the sandstone aquifer in Dane County, Wisconsin: Wisconsin Geological and Natural History Survey Information Circular 28, $91 \mathrm{p}$.

$-1975 \mathrm{~b}$, A digital-computer model for estimating hydrologic changes in the aquifer system in Dane County, Wisconsin: Wisconsin Geological and Natural History Survey Information Circular $30,40 \mathrm{p}$.

Meents, W.F., Bell, A.H., Rees, O.W., and Tilbury, W.G., 1952, Illinois oil-field brines, their geologic occurrence and chemical composition: Illinois State Geological Survey, Illinois Petroleum No. $66,38 \mathrm{p}$.

Nicholas, J.R., Sherrill, M.G., and Young, H.L., 1987, Hydrogeology of the Cambrian-Ordovician aquifer system at a test well in northeastern Illinois: U.S. Geological Survey Water-Resources Investigations Report 84-4165, $30 \mathrm{p}$. 
Ohio River Valley Water Sanitation Commission, 1976, Evaluation of the Ohio Valley region basal sandstone as a wastewater injection interval: Cincinnati, Ohio River Valley Water Sanitation Commission, $30 \mathrm{p}$.

Ostrom, M.E., 1967, Paleozoic stratigraphic nomenclature for Wisconsin: Wisconsin Geological and Natural History Survey Information Circular 8, 1 sheet.

Parker, M.C., 1971, The Maquoketa Formation (Upper Ordovician) in Iowa: Iowa Geological Survey Miscellaneous Map Series 1, scale $1: 1,000,000,6$ sheets.

Prickett, T.A., and Lonnquist, C.G., 1971, Selected digital computer techniques for groundwater resource evaluation: Illinois State Water Survey Bulletin 55, $62 \mathrm{p}$.

Sasman, R.T., Benson, C.R., Ludwigs, R.S., and Williams, T.L., 1982, Water-level trends, pumpage, and chemical quality in the Cambrian-Ordovician aquifer in Illinois, 1971-1980: Illinois State Water Survey Circular 154, $64 \mathrm{p}$.

Schicht, R.J., Adams, R.J., and Stall, J.B., 1976, Water resources availability, quality, and cost in northeastern Illinois: Illinois State Water Survey Report of Investigations 83, $90 \mathrm{p}$.

Schoenberg, M.E., 1984, Water levels and water-level changes in the Prairie du Chien-Jordan and Mount Simon-Hinckley aquifers, Twin Cities metropolitan area, Minnesota, 1971-80: U.S. Geological Survey Water-Resources Investigations Report 83-4237, 23 p.

Scott, R.C., and Barker, F.B., 1961, Ground-water sources containing high concentrations of radium, in Geological Survey research 1961: U.S. Geological Survey Professional Paper 424-D, p. D357-D359.

Shufeldt, G.A., Jr., 1865, History of the Chicago artesian well: Chicago, Religio-Philosophical Publishing Assn., p. 1-20 (publ. in 1897).

Siegel, D.I., 1989, Geochemistry of the Cambrian-Ordovician aquifer system in the northern Midwest, United States: U.S. Geological Survey Professional Paper 1405-D, 76 p.

Siegel, D.I., and Begor, K.F., 1989, The geochemistry of the sandstone aquifer, southern Wisconsin, in Swain, L.A., and Johnson, A.I., eds., Regional aquifer systems of the United States-Aquifers of the midwestern area: American Water Resources Association Monograph 13, p. 73-82.

Steinhilber, W.L., and Young, H.L., 1979, Plan of study for the Northern Midwest Regional Aquifer-System Analysis: U.S. Geological Survey Water-Resources Investigations Report 79-44, $20 \mathrm{p}$.

Suter, Max, Bergstrom, R.E., Smith, H.F., Emrich, G.H., Walton, W.C., and Larson, T.E., 1959, Preliminary report on groundwater resources of the Chicago region, Illinois: Illinois State Water Survey and State Geological Survey Cooperative Groundwater Report 1, 89 p.

Taylor, R.W., Butler, D.R., and Jansen, John, 1987, Geophysical logging of sandstone aquifers in Brookfield, Wisconsin [abs.]: Midwest Ground Water Conference annual meeting, 32d, Madison, Wis., October 28-30, 1987, Program with Abstracts, unpaginated.

Toth, J., 1962, A theory of ground water motion in small drainage basins in central Alberta, Canada: Journal of Geophysical Research, v. 67 , no. 11 , p. 4375-4387.

Trescott, P.C., 1975, Documentation of finite-difference model for simulation of three-dimensional ground-water flow: U.S. Geological Survey Open-File Report 75-438, $32 \mathrm{p}$.

U.S. Environmental Protection Agency, 1986, Maximum contaminant levels (subpart B of part 141, National interim primary drinkingwater regulations): U.S. Code of Federal Regulations, Title 40, Parts 100 to 149, revised as of July 1, 1986, p. 524-528.

U.S. Supreme Court, 1967, Wisconsin et al. v. Illinois et al.: U.S. Reports, v. 388, p. 426, June 12, 1967.
Visocky, A.P., 1982, Impact of Lake Michigan allocations on the Cambrian-Ordovician aquifer system: Illinois State Water Survey Contract Report 292, 36 p.

Visocky, A.P., Sherrill, M.G., and Cartwright, Keros, 1985, Geology, hydrology, and water quality of the Cambrian and Ordovician systems in northern Illinois: Illinois State Geological Survey, Illinois State Water Survey, and U.S. Geological Survey Cooperative Groundwater Report 10, $136 \mathrm{p}$.

Walton, W.C., and Csallany, Sandor, 1962, Yields of deep sandstone wells in northern Illinois: Illinois State Water Survey Report of Investigations $43,47 \mathrm{p}$.

Weidman, Samuel, and Schultz, A.R., 1915, The underground and surface water supplies of Wisconsin: Wisconsin Geological and Natural History Survey Bulletin 35, $664 \mathrm{p}$.

Willman, H.B., Atherton, Elwood, Buschbach, T.C., Collinson, Charles, Frye, J.C., Hopkins, M.E., Lineback, J.A., and Simon, J.A., 1975, Handbook of Illinois stratigraphy: Illinois State Geological Survey Bulletin 95, $261 \mathrm{p}$.

Willman, H.B., and Kolata, D.R., 1978, The Platteville and Galena Groups in northern Illinois: Illinois State Geological Survey Circular 502, $75 \mathrm{p}$.

Young, H.L., 1976, Digital-computer model of the sandstone aquifer in southeastern Wisconsin: Southeastern Wisconsin Regional Planning Commission (Waukesha) Technical Report 16, $42 \mathrm{p}$.

in press, Hydrogeology of the Cambrian-Ordovician aquifer system in the northern Midwest, United States: U.S. Geological Survey Professional Paper 1405-B.

Young, H.L., MacKenzie, A.J., and Mandle, R.J., 1989, Simulation of ground-water flow in the Cambrian-Ordovician aquifer system in the Chicago-Milwaukee area of the northern Midwest, in Swain, L.A., and Johnson, A.I., eds., Regional aquifer systems of the United States-Aquifers of the midwestern area: American Water Resources Association Monograph 13, p. 39-72.

\section{PROJECT PUBLICATIONS}

The following publications are a result of the Northern Midwest Regional Aquifer-System Analysis.

\section{ABSTRACTS}

Alexander, E.C., Jr., Siegel, D.I., and Milske, J.A., 1983, Isotopic studies of the Mt. Simon aquifer, southern Minnesota: American Geophysical Union Transactions, EOS, v. 64, no. 18, p. 225.

Franz, K.E., and Siegel, D.I., 1984, Geochemical trends in the sandstone aquifer, eastern Wisconsin: American Geophysical Union Transactions, EOS, v. 65, no. 16, p. 212.

Shedlock, R.J., and Eikenberry, S.E., 1982, Saline formation waters in the Cambrian-Ordovician aquifer in northwest Indiana: Geological Society of America, North-Central Section, annual meeting, 16th, West Lafayette, Ind., 1982, Abstracts with Programs, v. 15, no. 5, p. 287.

Siegel, D.I., 1983, Sulfur isotope chemistry, Cambrian-Ordovician aquifer, North-Central United States: American Geophysical Union Transactions, EOS, v. 64 , no. 45 , p. 704

1987, Geochemical evidence for possible dedolomitization in the sandstone aquifer, eastern Wisconsin: Midwest Ground Water Conference annual meeting, 32d, Madison, Wis., October 28-30, 1987, Program with Abstracts, unpaginated.

Siegel, D.I., and Franz, K.E., 1984, Isotopic studies of the sandstone aquifer, eastern Wisconsin: Geological Society of America annual meeting, 97th, Reno, Nev., 1984, Abstracts with Programs, v. 16, no. 6, p. 655 . 
Siegel, D.I., Kontis, A.L., and Mandle, R.J., 1982, The chemical evolution of water quality in the Cambrian-Ordovician aquifer, North-Central United States: American Geophysical Union Transactions, EOS, v. 63 , no. 33, p. 612.

Siegel, D.I., and Mandle, R.J., 1982, Geochemical evidence of Pleistocene glacial meltwater recharge to the Cambrian-Ordovician aquifer in the North-Central United States: American Geophysical Union Transactions, EOS, v. 63 , no. 18 , p. $325-326$.

-1983, Geochemical evidence for glaciation of the driftless area, southwestern Wisconsin: Geological Society of America annual meeting, 96th, Indianapolis, Ind., 1983, Abstracts with Programs, v. 15 , no. 6, p. 687 .

Signor, D.C., Kontis, A.L., Jorgensen, D.G., and Mandle, R.J., 1980, Ground-water flow regime based on preliminary data for regional aquifer systems: American Geophysical Union Transactions, EOS, v. 61 , no. 46, p. 952 .

Woodward, D.G., and Delin, G.N., 1982, Potentiometric surface of regional aquifers in the Hollandale embayment, southeastern Minnesota: American Geophysical Union Transactions, EOS, v. 63 , no. 33, p. 612.

Young, H.L., and MacKenzie, A.J., 1987, The Cambrian-Ordovician aquifer system in the northern Midwest-A regional study: Midwest Ground Water Conference annual meeting, 32d, Madison, Wis., October 28-30, 1987, Program with Abstracts, unpaginated.

\section{REPORTS}

Barnes, M.J., 1985, The extent and behavior of the mineralized water in the Mt. Simon Formation, northeastern Illinois: M.S. thesis, Northern Illinois University (De Kalb), $127 \mathrm{p}$.

Bennett, G.D., Kontis, A.L., and Larson, S.P., 1982, Representation of multiaquifer well effects in three-dimensional ground-water flow simulation: Ground Water, v. 20, no. 3, p. 334-341.

Burkart, M.R., and Buchmiller, R.C., in press, Regional aquifer evaluation of hydrologic factors and effects of pumping, St. PeterJordan aquifer, Iowa: U.S. Geological Survey Water-Resources Investigations Report 90-4009.

Delin, G.N., and Woodward, D.G., 1984, Hydrogeologic setting and the potentiometric surfaces of regional aquifers in the Hollandale embayment, southeastern Minnesota, 1970-80: U.S. Geological Survey Water-Supply Paper 2219, 56 p.

Emmons, P.J., 1987, An evaluation of the bedrock aquifer system in northeastern Wisconsin: U.S. Geological Survey Water-Resources Investigations Report 85-4199, $48 \mathrm{p}$.

Fassnacht, T.L., 1982, A seismic reflection study of the Precambrian basement along the Illinois-Wisconsin State line: M.S. thesis, Northern Illinois University (De Kalb), $103 \mathrm{p}$.

Franz, K.E., 1985, Geochemistry of the sandstone and Silurian aquifers in eastern Wisconsin: M.S. thesis, Syracuse University (Syracuse, N.Y.), $103 \mathrm{p}$.

Horn, M.A., 1983, Ground-water-use trends in the Twin Cities metropolitan area, Minnesota, 1880-1980: U.S. Geological Survey Water-Resources Investigations Report 83-4033, $37 \mathrm{p}$.

Imes, J.L., 1985, The ground-water flow system in northern Missouri, with emphasis on the Cambrian-Ordovician aquifer: U.S. Geological Survey Professional Paper 1305, $61 \mathrm{p}$.

Kontis, A.L., and Mandle, R.J., 1980, Data-base system for Northern Midwest Regional Aquifer-System Analysis: U.S. Geological Survey Water-Resources Investigations Report 80-104, 23 p.

1988, Modifications of a three-dimensional ground-water flow model to account for variable water density and effects of multiaquifer wells: U.S. Geological Survey Water-Resources Investigations Report 87-4265, $78 \mathrm{p}$.
Mandle, R.J., and Kontis, A.L., in press, Simulation of regional ground-water flow in the Cambrian-Ordovician aquifer system in the northern Midwest, United States: U.S. Geological Survey Professional Paper 1405-C.

Mossler, J.H., 1983a, Bedrock topography and isopachs of Cretaceous and Quaternary strata, east-central and southeastern Minnesota: Minnesota Geological Survey Miscellaneous Map Series M-52, scale 1:500,000, 2 pls.

$-1983 \mathrm{~b}$, Paleozoic lithostratigraphy of southeastern Minnesota: Minnesota Geological Survey Miscellaneous Map Series M-51, scale 1:500,000, 8 pls.

Nicholas, J.R., Sherrill, M.G., and Young, H.L., 1987, Hydrogeology of the Cambrian-Ordovician aquifer system at a test well in northeastern Illinois: U.S. Geological Survey Water-Resources Investigations Report 84-4165, $30 \mathrm{p}$.

Siegel, D.I., 1989, Geochemistry of the Cambrian-Ordovician aquifer system in the northern Midwest, United States: U.S. Geological Survey Professional Paper 1405-D, $76 \mathrm{p}$.

Siegel, D.I., and Begor, K.F., 1989, The geochemistry of the sandstone aquifer, southern Wisconsin, in Swain, L.A., and Johnson, A.I., eds., Regional aquifer systems of the United States-Aquifers of the midwestern area: American Water Resources Association Monograph 13, p. 73-82.

Siegel, D.I., and Mandle R.J., 1984, Isotopic evidence for glacial meltwater recharge to the Cambrian-Ordovician aquifer, NorthCentral United States: Journal of Quaternary Research, v. 22, p. $328-335$.

Steinhilber, W.L., and Young, H.L., 1979, Plan of study for the Northern Midwest Regional Aquifer-System Analysis: U.S. Geological Survey Water-Resources Investigations Report 79-44, $20 \mathrm{p}$.

Visocky, A.P., Sherrill, M.G., and Cartwright, Keros, 1985, Geology, hydrology, and water quality of the Cambrian and Ordovician systems in northern Illinois: Illinois State Geological Survey, Illinois State Water Survey, and U.S. Geological Survey Cooperative Groundwater Report 10, $136 \mathrm{p}$.

Woodward, D.G., 1984, Areal lithologic changes in aquifers in southeastern Minnesota as determined from natural-gamma borehole logs: National Water Well Association Conference on Surface and Borehole Geophysical Methods in Ground Water Investigations, San Antonio, Tex., February 7-9, 1984, Proceedings, p. 788-800. 1985, Trends in municipal-well installations and aquifer utilization in southeastern Minnesota, 1880-1980: U.S. Geological Survey Water-Resources Investigations Report 83-4222, 99 p.

1986, Hydrogeologic framework and properties of regional aquifers in the Hollandale embayment, southeastern Minnesota: U.S. Geological Survey Hydrologic Investigations Atlas 677, 2 sheets.

Young, H.L., in press, Hydrogeology of the Cambrian-Ordovician aquifer system in the northern Midwest, United States: U.S. Geological Survey Professional Paper 1405-B.

Young, H.L., MacKenzie, A.J., and Mandle, R.J., 1989, Simulation of ground-water flow in the Cambrian-Ordovician aquifer system in the Chicago-Milwaukee area of the northern Midwest, in Swain, L.A., and Johnson, A.I., eds., Regional aquifer systems of the United States-Aquifers of the midwestern area: American Water Resources Association Monograph 13, p. 39-72.

Young, H.L., Mandle, R.J., Kontis, A.L., and Siegel, D.I., 1989, The Cambrian-Ordovician regional aquifer system in the northern Midwest-A summary, in Swain, L.A., and Johnson, A.I., eds., Regional aquifer systems of the United States-Aquifers of the midwestern area: American Water Resources Association Monograph 13, p. 5-37. 





\section{SELECTED SERIES OF U.S. GEOLOGICAL SURVEY PUBLICATIONS}

\section{Periodicals}

Earthquakes \& Volcanoes (issued bimonthly).

Preliminary Determination of Epicenters (issued monthly).

\section{Technical Books and Reports}

Professional Papers are mainly comprehensive scientific reports of wide and lasting interest and importance to professional scientists and engineers. Included are reports on the results of resource studies and of topographic, hydrologic, and geologic investigations. They also include collections of related papers addressing different aspects of a single scientific topic.

Bulletins contain significant data and interpretations that are of lasting scientific interest but are generally more limited in scope or geographic coverage than Professional Papers. They include the results of resource studies and of geologic and topographic investigations. as well as collections of short papers related to a specific topic.

Water-Supply Papers are comprehensive reports that present significant interpretive results of hydrologic investigations of wide interest to professional geologists, hydrologists, and engineers. The series covers investigations in all phases of hydrology, including hydrogeology, availability of water, quality of water, and use of water.

Circulars present administrative information or important scientific information of wide popular interest in a format designed for distribution at no cost to the public. Information is usually of short-term interest.

Water-Resources Investigations Reports are papers of an interpretive nature made available to the public outside the formal USGS publications series. Copies are reproduced on request unlike formal USGS publications, and they are also available for public inspection at depositories indicated in USGS catalogs.

Open-File Reports include unpublished manuscript reports, maps, and other material that are made available for public consultation at depositories. They are a nonpermanent form of publication that may be cited in other publications as sources of information.

\section{Maps}

Geologic Quadrangle Maps are multicolor geologic maps on topographic bases in 7.5- or 15-minute quadrangle formats (scales mainly $1: 24,000$ or $1: 62,500$ ) showing bedrock, surficial, or engineering geology. Maps generally include brief texts; some maps include structure and columnar sections only.

Geophysical Investigations Maps are on topographic or planimetric bases at various scales; they show results of surveys using geophysical techniques, such as gravity, magnetic, seismic, or radioactivity, which reflect subsurface structures that are of economic or geologic significance. Many maps include correlations with the geology.

Miscellaneous Investigations Series Maps are on planimetric or topographic bases of regular and irregular areas at various scales; they present a wide variety of format and subject matter. The series also includes 7.5-minute quadrangle photogeologic maps on planimetric bases that show geology as interpreted from aerial photographs. Series also includes maps of Mars and the Moon.
Coal Investigations Maps are geologic maps on topographic or planimetric bases at various scales showing bedrock or surficial geology, stratigraphy, and structural relations in certain coal-resource areas.

Oil and Gas Investigations Charts show stratigraphic information for certain oil and gas fields and other areas having petroleum potential.

Miscellaneous Field Studies Maps are multicolor or black-andwhite maps on topographic or planimetric bases for quadrangle or irregular areas at various scales. Pre-1971 maps show bedrock geology in relation to specific mining or mineral-deposit problems; post-1971 maps are primarily black-and-white maps on various subjects such as environmental studies or wilderness mineral investigations.

Hydrologic Investigations Atlases are multicolored or blackand-white maps on topographic or planimetric bases presenting a wide range of geohydrologic data of both regular and irregular areas; principal scale is $1: 24,000$, and regional studies are at $1: 250,000$ scale or smaller.

\section{Catalogs}

Permanent catalogs, as well as some others, giving comprehensive listings of U.S. Geological Survey publications are available under the conditions indicated below from the U.S. Geological Survey, Book and Open-File Report Sales, Federal Center, Box 25425, Denver, CO 80225. (See latest Price and Availability List.)

"Publications of the Geological Survey, 1879-1961" may be purchased by mail and over the counter in paperback book form and as a set of microfiche.

"Publications of the Geological Survey, 1962-1970" may be purchased by mail and over the counter in paperback book form and as a set of microfiche.

"Publications of the U.S. Geological Survey, 1971-1981" may be purchased by mail and over the counter in paperback book form (two volumes, publications listing and index) and as a set of microfiche.

Supplements for 1982, 1983, 1984, 1985, 1986, and for subsequent years since the last permanent catalog may be purchased by mail and over the counter in paperback book form.

State catalogs, "List of U.S. Geological Survey Geologic and Water-Supply Reports and Maps For (State)," may be purchased by mail and over the counter in paperback booklet form only.

"Price and Availability List of U.S. Geological Survey Publications," issued annually, is available free of charge in paperback booklet form only.

Selected copies of a monthly catalog "New Publications of the U.S. Geological Survey" are available free of charge by mail or may be obtained over the counter in paperback booklet form only. Those wishing a free subscription to the monthly catalog "New Publications of the U.S. Geological Survey" should write to the U.S. Geological Survey, 582 National Center, Reston, VA 22092.

Note.-Prices of Government publications listed in older catalogs, announcements, and publications may be incorrect. Therefore, the prices charged may differ from the prices in catalogs, announcements, and publications. 